INTER NATIONAL MONETARY FUND

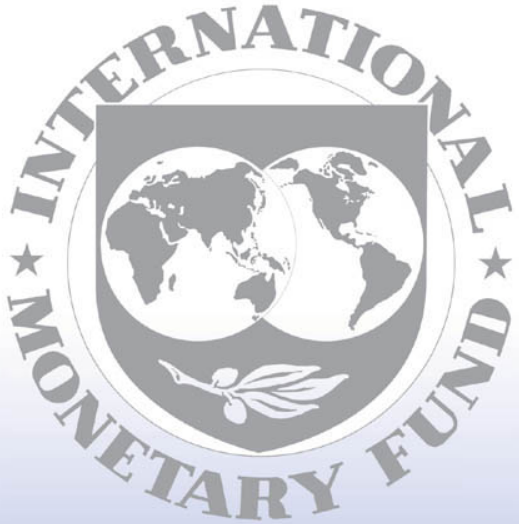

Staff

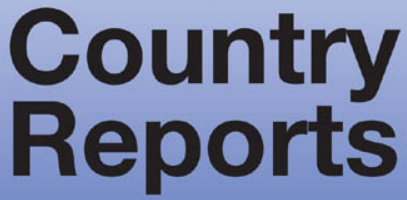




\section{United Republic of Tanzania: Poverty Reduction Strategy Paper- Annual Implementation Report 2006/07}

Poverty Reduction Strategy Papers (PRSPs) are prepared by member countries in broad consultation with stakeholders and development partners, including the staffs of the World Bank and the IMF. Updated every three years with annual progress reports, they describe the country's macroeconomic, structural, and social policies in support of growth and poverty reduction, as well as associated external financing needs and major sources of financing. This country document for the United Republic of Tanzania, dated October, 2007, is being made available on the IMF website by agreement with the member country as a service to users of the IMF website.

To assist the IMF in evaluating the publication policy, reader comments are invited and may be sent by e-mail to publicationpolicy@imf.org.

Copies of this report are available to the public from

International Monetary Fund • Publication Services

$70019^{\text {th }}$ Street, N.W. • Washington, D.C. 20431

Telephone: (202) 623-7430 • Telefax: (202) 623-7201

E-mail: publications@imf.org •Internet: http://www.imf.org

Price: $\$ 18.00$ a copy

\section{International Monetary Fund Washington, D.C.}


This page intentionally left blank

CInternational Monetary Fund. Not for Redistribution 


\section{UNITED REPUBLIC OF TANZANIA}

MKUKUTA ANNUAL IMPLEMENTATION REPORT 2006/07

“MANAGING FOR DEVELOPMENT RESULTS"

CInternational Monetary Fund. Not for Redistribution 
Ministry of Planning, Economy and Empowerment

\author{
Poverty Eradication Division
}

October, 2007

CInternational Monetary Fund. Not for Redistribution 


\section{Table of Contents}

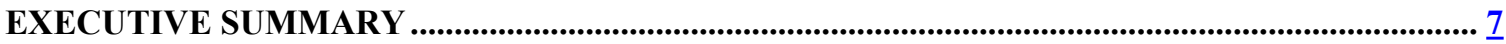

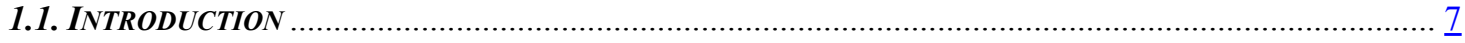

1.3. IMPROVED QUALITY OF LIFE AND SOCIAL WELL BEING ................................................. 9

1.4. GOVERNANCE AND ACCOUNTABILITY .................................................................................... 10

1.5. MKUKUTA FINANCING ...................................................................................................................... 11

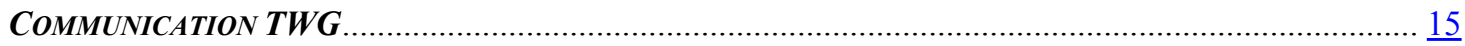

1.7. KEY ISSUES AND THE WAY FORWARD ................................................................................... 16

CHAPTER ONE: BACKGROUND AND INTRODUCTION ...................................................... 17

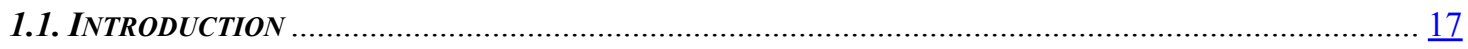

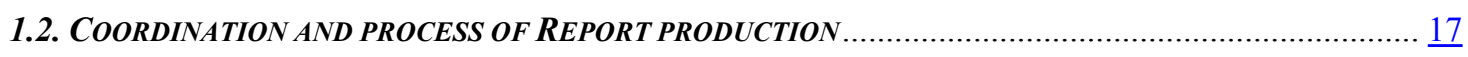

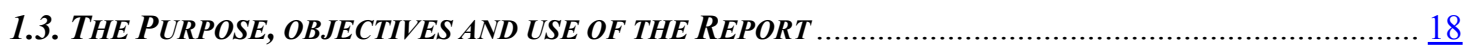

1.4 HARMONIZATION AND ALIGNMENT OF KEY NATIONAL PROCESSES AND MAIR …........................... 18

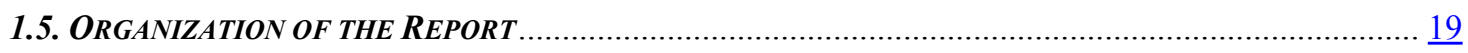

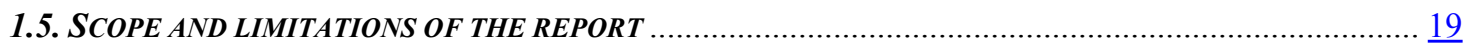

CHAPTER TWO: GROWTH AND REDUCTION OF INCOME POVERY .................................... 21

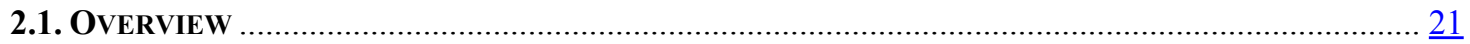

Goal 1: Ensuring sound economic management …............................................................ 21

Goal 2: Promoting sustainable and broad based growth .......................................................... 25

Goal 3: Improved food availability and accessibility at household level in urban and rural areas $\underline{30}$

Goal 4 \& 5: Reducing income poverty (Urban and Rural) .................................................... $\underline{31}$

2.4. Status AND Progress of Sector ReVIEW ......................................................................... $\underline{33}$

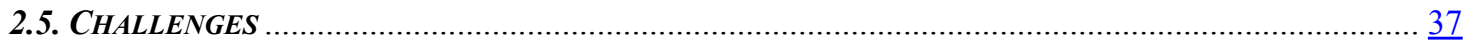

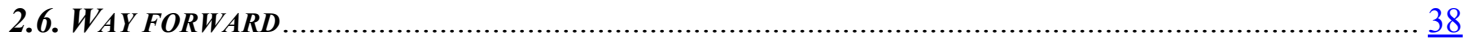

CHAPTER THREE: IMPROVED QUALITY OF LIFE AND SOCIAL WELBEING ........................ $\underline{41}$

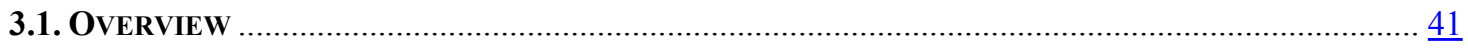

3.2 PERformanCE AND Progress ............................................................................................ 41

Goal 1: Ensuring equitable access to primary and secondary education for boys and girls,

Universal literacy among men and women and expansion of higher, technical and vocational education

Goal 2: Improved survival, health and well-being of all children and women and especially vulnerable groups.

CInternational Monetary Fund. Not for Redistribution 
Goal 3: Access to clean, affordable and safe water, sanitation, decent shelter and a safe and sustainable environment and thereby, reduced vulnerability from environmental risk.

Goal 4: Adequate social protection and provision of basic needs and services for the vulnerable and needy.

Goal 5: Effective systems to ensure universal access to quality and affordable public services. ... $\underline{48}$

3.3. STATUS AND PROGRESS OF SECTOR REVIEW.

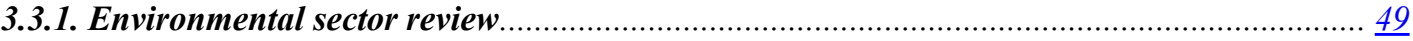

3.3.2 Education Sector Review.........................................................................................

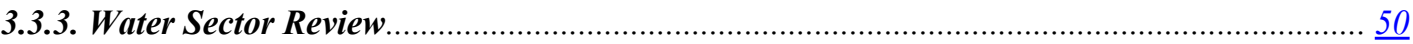

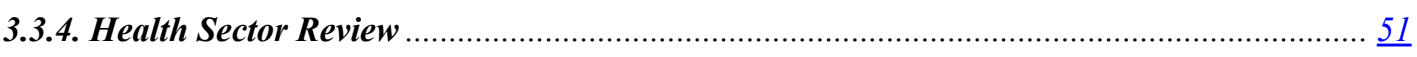

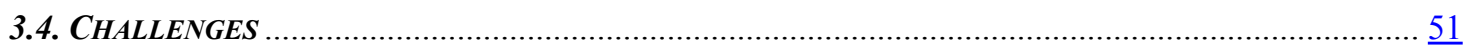

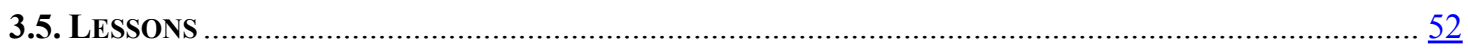

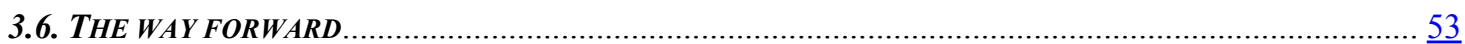

CHAPTER FOUR: GOVERNANCE AND ACCOUNTABILITY ...................................................... 55

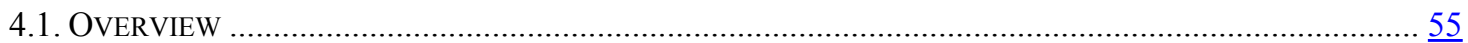

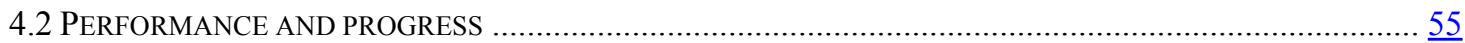

Goal 1: Structures and systems of governance as well as the rule of law are democratic, participatory, representative, accountable and inclusive ........................................................ $\underline{55}$

Goal 2: Equitable allocation of public resources with corruption effectively addressed ................ $\underline{57}$

Goal 3: Effective public service framework in place to provide foundation for service delivery

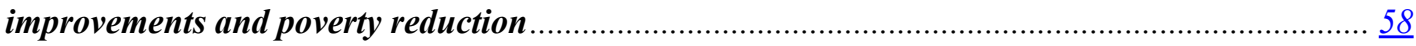

Goal 4: Rights of the poor and vulnerable groups are protected and promoted in the justice system

Goal 5: Reduction of Political and Social Exclusion and Intolerance.

Goal 6: Improved personal and material securities, reduced crime, eliminate sexual abuse and domestic violence. $\underline{61}$

Goal 7: National cultural identities enhanced and promoted .................................................... $\underline{63}$

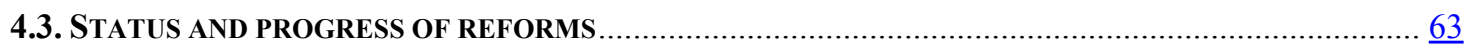

4.3.1 The Legal Sector Reform Program (LSRP) ......................................................................

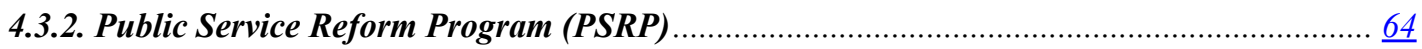

4.3.3. Local Government Reform Program (LGRP) .................................................................. $\underline{65}$

4.3.4. National Anti-Corruption Strategy and Action Plan (NACSAP) ……….......................... $\underline{65}$

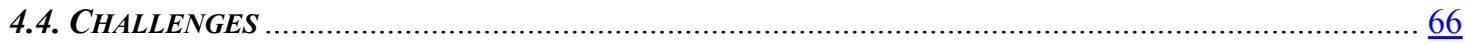

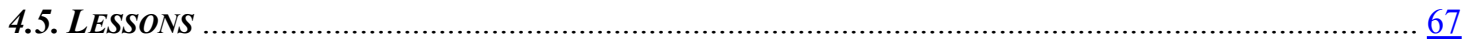

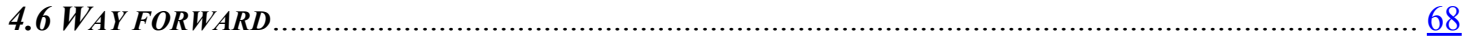

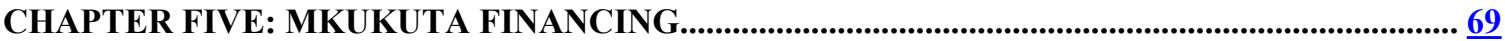




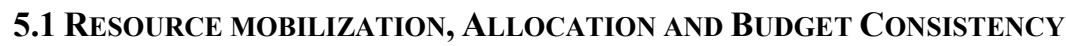

5.2. MKUKUTA STRUCTURE AND THE BUDGET:....................................................................

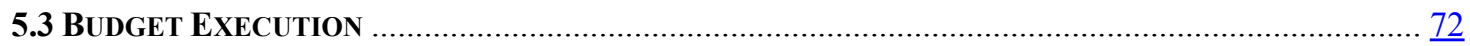

5.4.1. Status on budget reporting mechanisms..................................................................... $\underline{74}$

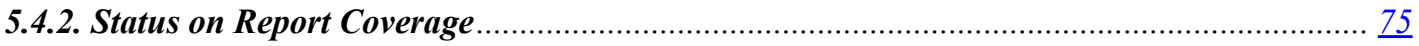

5.5. OTHER POLICIES RELATED TO GOVERNMENT BUDGET .......................................................... $\underline{75}$

CHAPTER SIX: MONITORING AND EVALUATION........................................................................ 77

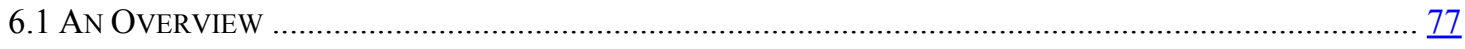

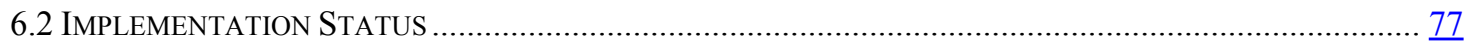

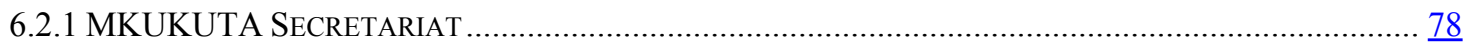

6.2.2. RESEARCH AND ANALYSIS TECHNICAL WORKING GROUP …............................................ $\underline{79}$

6.2.3. SURVEY AND ROUTINE DATA TWG ..................................................................................... $\underline{80}$

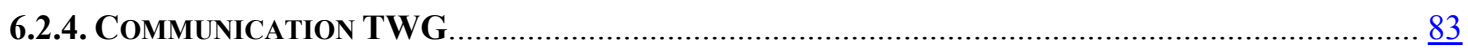

6.3.1 PROGRESS ON HARMONIZATION INITIATIVES ............................................................................ $\underline{85}$

6.4 CHALLENGES AND LESSONS LEARNED .............................................................................. $\underline{86}$

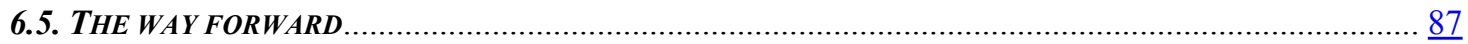

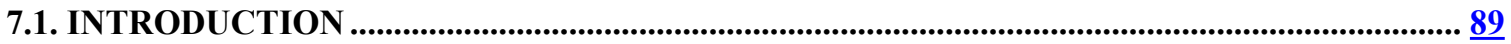

7.2. ISSUES FOR FURTHER ACTION.................................................................................................. 89

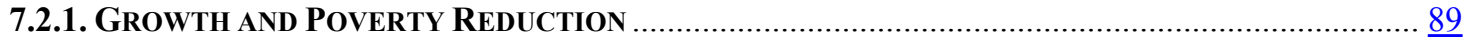

7.2.2. SOCIAL WELLBEING AND QUALITY OF LIFE ................................................................... 90

7.2.3. GOVERNANCE AND ACCOUNTABILITY ................................................................................ 91

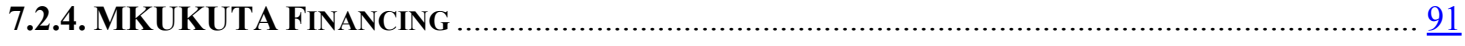

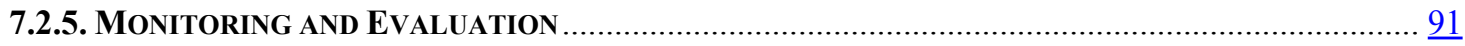

ANNEX 1: SUMMARY OF OUTCOMES, PERFORMANCE, AND CHALLENGES ....................... 92

CLUSTER I: GROWTH AND REDUCTION OF INCOME POVERTY ………............................... $\underline{92}$

CLUSTER II: IMPROVEMENT OF QUALITY OF LIFE AND SOCIAL WELL BEING ……… 97

CLUSTER III: GOVERNANCE AND ACCOUNTABILITY ….............................................. 121

ANNEX II: STATUS OF MKUKUTA IMPLEMENTATION FRAMEWORK.............................. 131

CInternational Monetary Fund. Not for Redistribution 
AGOA African Growth Opportunities Arrangement

AIDS Acquired) Immune) Deficiency) Syndrome)

AMSDP Agricultural Marketing Systems Development Program

ARV Anti-Retroviral

ASDS(P) Agricultural Sector Development Strategy (Program)

ASR Agricultural Sector Review

BEST Business Environment Strengthening for Tanzania

BERS Budget Execution Reporting System

CCRO Certificates of Customary Rights of Occupancy

CMU Cash Management Unit

CSO Civil Society Organization

DADP District Agricultural Development Plans

DHS (T) Tanzania Demographic and Health Survey

DPs Development Partners

DTS Distributive Trade Survey

EMA Environmental Management Act

EPA ?Economic Partnership Agreement

EPZ Export Processing Zone

FDI Foreign Direct Investment

GBS General Budget Support

GDP(mp) Gross Domestic Product(market price)

GOT The Government of Tanzania

HBS Household Budget Survey

HIPC Heavily Indebted Poor Country

HIV Human Immune Virus

IFMS Integrated Financial Management System

ILFS Integrated Labor Force Survey

KM Kilometers

LGA Local Government Authorities

LGCDG Local Government Capital Development Grant

LGRP Local Government Reform Program 


\begin{tabular}{|c|c|}
\hline LSRP & Legal Sector Reform Program \\
\hline$M \& E$ & Monitoring and Evolutions \\
\hline MAIR & MKUKUTA Annual Implementation Report \\
\hline MDA & (government sector) Ministry, Department and Agency \\
\hline MDRI & Multilateral Debt Relief Initiative \\
\hline MKUKUTA & Mkakati wa Kukuza Uchumi na Kupunguza Umaskini Tanzania (National \\
\hline (NSGRP) & Strategy for Growth and Reduction of Poverty) \\
\hline MMMP & MKUKUTA Monitoring Master Plan \\
\hline MPEE & Ministry of Planning, Economy and Empowerment \\
\hline MTEF & Medium Term Expenditure Framework \\
\hline MTSPBR & Medium Term Strategic Planning, Budgeting and Reporting Manual \\
\hline MUVI & Muunganisho wa Ujasiriamali Vijijini \\
\hline NACSAP & National Anti-Corruption Strategy and Action Plan \\
\hline $\mathrm{NAO}$ & National Audit Office \\
\hline NBS & National Bureau of Statistics \\
\hline $\mathrm{NGO}$ & Non Governmental Organizations \\
\hline NMSPF & National Multi-sectoral Social Protection Framework \\
\hline NPS & National Panel Survey \\
\hline PAF & Performance Assessment Framework \\
\hline PER & Public Expenditure Review \\
\hline PHDR & Poverty and Human Development Report \\
\hline PHSDP & Primary Health Services Development Program \\
\hline PHSDP & Primary Health Services Development Plan \\
\hline PLWHA & People Living with HIV and AIDS \\
\hline PMO-RALG & Prime Minister's Office-Regional Administration \& Local Government \\
\hline PMS & Poverty Monitoring System \\
\hline PSMP & Power Sector Master Plan \\
\hline PSRP & Public Service Reform Program \\
\hline REPOA & Research of Poverty Alleviation \\
\hline RIMKU & Ripoti ya Utekelezaji ya MKUKUTA \\
\hline RVF & Rift Valley Fever \\
\hline RWSSP & Rural Water Supply and Sanitation Projects \\
\hline SBAS & Strategic Budget Allocation System \\
\hline SEZ & Special Economic Zone \\
\hline
\end{tabular}


SGR

SMEs

SUA-LWC

$\mathrm{TB}$

THIS

TSMP

TWGs

WHO

WSDP

PRBS

PRSC

PRGF
Strategic Grain Reserve

Small and Medium size Enterprises

Strategy for Urgent Actions on Land Degradation and Water Catchments Tuberculosis

Tanzania HIV/AIDS and Malaria Indicator Survey

Tanzania Statistical Master Plan

Technical Working Groups

World Health Organization

Water Sector Development Program

Poverty Reduction Budget Support

Poverty Reduction Support Credit

Poverty Reduction Growth Facility 


\section{EXECUTIVE SUMMARY}

\subsection{Introduction}

The MKUKUTA Annual Implementation Report 2006/07 (MAIR) is one of the outputs of the Government's monitoring system. The objective of the Government in producing this report is to contribute to the overall Government reporting system that includes output reporting by MDAs, LGAs and non-state actors implementing MKUKUTA activities. The report is based on analysis of progress at goal level and provides an overview of the performance, challenges, lessons learned, and the next steps within each MKUKUTA cluster. It also includes progress on other processes and reforms, and how these have contributed to achievements of MKUKUTA outcomes.

The purpose of this report is to inform stakeholders on the progress in MKUKUTA implementation and associated processes, with a view to stimulate dialogue on key issues, and inform subsequent planning, budgeting and implementation.

\subsection{Growth and Reduction of Income Poverty}

Various interventions were implemented during the period under review that has bearing to outcomes produced. These interventions include the ongoing reforms, sound monetary policy, National Debt Strategy, financial sector reforms and other interventions focusing on investment promotion, employment generation, export promotion, infrastructure and human resource development and the expansion of irrigation schemes and provision of agricultural credit and inputs to small holders.

These have yielded substantial progress. Growth performance is still on track although it slackened slightly to 6.2 percent in 2006 , compared to 6.8 percent attained in 2005 . The decline is mainly attributable to drought and energy crises. Agriculture, manufacturing, electricity and water sectors were the most hit by the crises. Total exports of goods and services grew to US\$ 3,133.1 million in 2006 from US\$ 2,945.5 million in 2005. The growth was mainly contributed by mineral and service exports (including earnings from tourism). Government domestic revenue collection as a percentage of GDPmp (tax and non tax revenue) increased to 15.6 percent in 2006/07 from 14.3 percent in 2005/06. Domestic credit to private sector has increased from 11.0 percent of GDPmp in 2005 to 12.5 percent in 2006. 
Significant achievement has been recorded on the national debt in the recent years. The external debt stock in the year under review was estimated at US\$5,749.0 or about 35percent of GDP compared to 50 percent of GDP as MKUKUTA requires. The total external debt is equivalent to 80.0 percent of the total national debt stock. Official foreign reserve has been equivalent of 5.3 moths of import as compared to 6 months of import in 2005. Three major reasons explain the decline: (i) increased import bills caused by increased petroleum prices, (ii) an increase in the importation of capital goods and (iii) increases in the importation of foodstuffs in response to the drought. The trend in export earnings as percentage of GDP is however on the increase despite marginal decrease from 22.2 percent in 2005/06 to 21.9 percent in $2006 / 07$.

Manufacturing sector registered growth of 8.6 percent in 2006 compared to 9 percent in 2005 . As noted earlier, the decline again is explained by power crisis which increased the cost of electricity as well as the increase in the price of industrial oil. Agricultural sector grew by 4.1 percent in 2006 due to drought. The crop sub-sector grew by 4.0 percent in 2006 compared to 5.2 percent in 2005. Livestock sub sector grew by 4.1 percent in 2006, against MKUKUTA targets of 9percent by 2010. Growth in the mining sector increased from 15.7 percent in 2005 to 16.4 percent in 2006. The contribution of the sector to GDP only increased from 3.5 percent in 2005 to 3.8 percent in 2006. The increase comes from both large and small scale miners.

Participation of the informal sector and SMEs (including cooperatives) in the mainstream economy indicates a substantial increase in the share of labor force employed in the informal sector - from 5.3 percent in 2000/01 to 9.3 percent in 2005/06. The government continues to promote the sector using various instruments such as informal sector exhibition for East African Countries, and demand driven skills programs.

There is some progress on the Council roads, whereby $13,353 \mathrm{~km}$ of roads were scheduled for rehabilitation. By April 2007, a total of 3,181km of council roads were rehabilitated. Notable progress has also been registered in the trunk and regional road sector, whereby the percentage of trunk and regional roads in good and fair conditions increased from 51 percent in 2000 to 78 percent by December 2006.

Food crop production reached 10.9 million tones in 2005/06. This resulted in food Self Sufficient Ratio (SSR) of 112 percent which is in line with MKUKUTA targets. 


\subsection{Improved Quality of Life and Social Well being}

The observed results in this area are associated by various programmes implemented by the government and other actors in sectors of education, water and health and social protection. Results are discussed below on each of the goals per sector.

The government recognizes the importance of education in enhancing poverty eradication initiatives in the country. It is thus fully committed towards expanding access to and quality of education at all levels but with a focus on basic and secondary education. That is why it appreciates the fact that expansion in educational facilities and access should move hand in hand with the maintenance of quality of education delivered at various levels. Most indicators in education have registered considerable improvements. For instance, Gross Enrolment Ratio and Net Enrolment Ratio of both boys and girls including children with disabilities at primary schools also has increased from 114.4 percent and 96.1 percent in 2006 to 114.4 percent and 97.3 percent in 2007 respectively.

The Health outcome reveals mixed performance. Infant and under-five mortality rates exhibited a substantial decline, however, maternal mortality increased from 529 per 100,000 live births (1996 DHS) to 578 per 100,000 live births (2004/05 DHS). This has been partly attributed to the impact of the HIV and AIDS pandemic. Water and Sanitation outcome have shown a modest progress over the last two years. Supply of clean and safe water in rural areas has increased from 53.5 percent in 2005/06 to 55.7 percent in 2006/07, while in urban the increase was from 73 percent in 2005/06 to 78 percent in 2006/07.

MKUKUTA clearly states the need for a social protection policy framework that will ensure that the needs of the poor are adequately addressed; including preventing the population from falling into poverty and vulnerability. The National Multi-sectoral Social Protection Framework (NMSPF) therefore builds on national efforts to eradicate poverty. It is a social, economic and political measure aimed at ensuring the increased focus, investment and engagement of the Tanzanian population in addressing causes of poverty so that they can monitor progress and benefit from economic growth. It is an instrument that will guide the coordination, implementation, management, harmonization, funding and sustainability of social protection interventions. The NMSPF prioritizes the needs of the less economically active households/individuals and those who are unable to sufficiently address shocks or risks associated with poverty and vulnerability. These groups include children and young people, 
women, people with disabilities, the elderly and People Living with HIV and AIDS (PLWHA's).

There are some notable improvements in the area of quality and affordable public services. Preliminary information indicates that 86 percent of the communities in rural areas spent 30 or fewer minutes to reach the nearest road passable throughout the year. Preliminary information also shows that, communities in Dar es Salaam and other urban areas are closer to health services than their counter parts in rural areas, with 93 percent in Dar es Salaam using 30 minutes or less to reach the nearest dispensary or a health center.

\subsection{Governance and Accountability}

To ensure that growth is broad-based and that improvement of quality life and social well being takes place, good governance has to prevail. There has been substantial improvement in representation and gender equity in all levels. Proportion of women in decision making position at Central government was 26.8 percent in 2005 and increased to 29.1 percent in 2006 which comes very close to MKUKUTA target of 30 percent. Other indicators are generally favorable in the area of representation both in the public service and political representation in all levels. With respect to the rule of law, significant progress has also been made. For instance the government decreed and put a clause that provides for ruling of cases within 90 days after completion of hearing. Ruling of land and human right cases were 32 percent and 70 percent respectively.

Efforts have been put in place to ensure equitable allocation of public resources and addressing the corruption vice, the government has instituted measures to improve domestic revenue collection. The government has also strengthened the National Audit Office (NAO), the Public Procurement Act and procedures. The number of cases reported by PCCB has increased significantly from 1,244 in 2000 to 3,121 in 2005 .

Effective Public service delivery is vital for poverty reduction. Improvement in quality, accessibility and affordability of services are gauged through clients' perception. In terms of accessibility to services, recent information on community characteristics indicates that 69 percent, 90 percent, 93 percent of rural areas, other urban centers, and Dar es Salaam respectively, are reporting to use 30 or less minutes to reach the nearest health center or dispensary. A significant improvement has been registered with regard to D by $\mathrm{D}$. The application of formula based allocation of development funds under Local Government Capital 
Development Grant (LGCDG) system has resulted into an increase of resources flowing to LGAs up to 19.7 percent (2007/08) compared to 16.1 percent during 2006/07 financial year.

The government recognizes the need for gauging overtime the efficiency of the judicial system particularly in relation to vulnerable groups. In order to realize the goal on protection and promotion of the rights of the vulnerable groups, judicial system focuses on improvement of outstanding court cases backlog, case screening and prosecution process.

A number of strategies have been applied such as enhancement of the capacity of the Commission for Human Rights, creating awareness of stakeholders regarding human rights, building capacity of NGOs on monitoring and reporting human rights abuse, and promotion of collaboration to regional and international human rights agencies. These have resulted into more complaints received and resolved.

Satisfactory progress has been made in the reported number of cases of crimes whereby there is a significant increase of file cases in both levels of judiciary. Notable achievements in terms of reduction of reported number of incidences of crime at Police Stations has declined for about 17 percent in year 2006 compared to year 2005. There also significant progress in the areas of specialized courts. The Commercial Court disposed 140 commercial disputes out of 153 in 2006. The Land Court disposed 476 out of 787 land disputes in 2005/06 and 612 out of 1915 in 2006/07.

There are challenges in relation to information posting in the notice board. Most of the notice boards are inaccessible as they are found in the district headquarters. Other challenges relates to available data on Certificates of Customary Rights of Occupancy, inadequate infrastructures, inadequate human resource and capacity building to implement interventions. Although some progress has been made in the area of legal reforms yet there are still challenges in relation to improvement of the judiciary system. Skills development and enhancement in Human Rights understanding and frequent monitoring, modern technology and equipment for dissemination and sensitization also stands to be a key challenge.

\subsection{MKUKUTA Financing}

Implementation of MKUKUTA lies not only on the public sector but also other non state actors. Given the complex nature in capturing information on contributions of other players in MKUKUTA implementation, this report reflects on the government financing as a major 
contributor. Notable achievements have been made including an upsurge in development partners' budget support, from Tshs 1,030 billion in the first two years of PRS to Tshs 3,090 billion in the first two years of MKUKUTA implementation. Domestic revenue collection also has risen significantly, from Tshs 1,973 billion in the first two years of PRS to Tshs 4,897 billion in the first two years of MKUKUTA implementation. These increases are partly on account of major reforms undertaken in the main collecting agents for domestic revenues, and improved public finance management which has enhanced development partners' confidence in Tanzania.

The approved budget to implement MKUKUTA in 2006/07 was 48 percent of the total budget allocations. The remaining 52 percent was for projects and programs that does not have direct link to MKUKUTA targets and outcomes. This category includes Wages and Salaries, LGAs and CFS which account for 18 percent, 12 percent and 10 percent of total budget in 2006/07 respectively. Out of the budget for MKUKUTA interventions, 46 percent was budgeted for the implementation of policies, programs and projects under Cluster 1, 36 percent for Cluster 2 and 18 percent for Cluster 3. This is in line with the objective of scaling up growth and increasing the income for poverty reduction of the poor majority. The government is being working on establishing the actual expenditure for 2006/07 derived from the IFMS based on MKUKUTA clusters.

Preliminary analysis of the actual releases for FY 2006/07 shows that disbursement of funds for the implementation of various MKUKUTA activities was satisfactory, albeit with some deviations from initial budget allocations. These deviations were attributed mainly to the government decision to reallocate funds from less to more priority areas in response to power crisis experienced in the first half of 2006/07, food shortages, oil prices and increasing domestic interest payments.

There have been improvements overtime in budget reporting and transparency in Tanzania. Reporting requirements are stipulated in the Public Finance Act of 2001, which is operationalized through the government's accounting procedure manuals. To facilitate, monitoring and execution, the Government is developing a framework for MKUKUTA - based analysis of budget execution results, which analysis shall be reported through the BERs. In the meantime, the policy link to budget execution is assessed through assessment of consistence between SBAS based allocations and actual expenditures (i.e. budget variations) and the impacts on poverty through the MKUKUTA Monitoring System. 
Despite of these remarkable achievements in the areas of Resource mobilization, Allocation, Budget Consistency, Execution, Reporting and transparency, there are several challenges remaining:

1. To concretize and integrate the non state actors' contribution in poverty reducing efforts. The effectiveness of the use of public resources would benefit from integration of private sector and civil society interventions in the planning process. Various players, including the private sector, non-state actors and development partners will be encouraged to share information related to poverty reduction efforts in the course of developing the next MKUKUTA implementation report, as the first step towards full integration of such inputs in the plans of different sectors.

2. Resources generated for MKUKUTA implementation are not sufficient to cover adequately earmarked interventions. Resources mobilization is therefore at centre stage of poverty reduction strategies. The Government will continue to seek ways to increase domestic tax and non - tax revenues, while encouraging development partners to increase their contribution in line with commitments at international and local (Tanzania) level.

3. The existing system fails to match complexities introduced by multiple channels of funding programs at the district levels. These complexities in the budget process call for measures to rationalize the funds flow and ensure that the systems remain transparent. Thus, instituting classification and reporting mechanisms for compiling comprehensive fiscal information will be accorded more attention in the next year of MKUKUTA implementation

4. Foreign resources predictability is still an issue to be addressed. The challenge is unpredictability and delay in capturing information related to development funds (most of which is financed by donors) against the approved estimates.

5. The need for guidance on the level of details on initial budget submission by MDAs to avoid the highly detailed (activity) submissions which normally lack a strategic framework, and

6. The need to improve the connectivity (linkage) between budget and program documents, as well as coordination and authority between budget and program officers within MDAs. 


\subsection{Monitoring and Evaluation}

Implementation status of the MKUKUTA Monitoring System covers the period from 2005/06 and 2006/07. This is due to the fact that 2005/06 was a transition year where the system itself was under review; therefore much of the progress was not reported.

\section{MKUKUTA Secretariat}

During 2005/07, MKUKUTA Secretariat coordinated the review of the Poverty Monitoring System, and the development of the MKUKUTA Monitoring System. The challenge now is to strengthen the Management Information Systems of MDAs as well as LGAs in order to improve the quality of data and frequency of information. It also facilitated the functioning of Technical Working Groups and the Technical Committee. An annual calendar of meetings of all committees and TWGs was agreed in early 2006. Other achievement includes the strengthening of communication and networks between the Secretariat and other stakeholders. Throughout 2005-2007, the Secretariat in collaboration with central ministries has been involved in the harmonization agenda of planning, budgeting and reporting within Government processes. Important accomplished task in relation to harmonization is the development of the Medium Term Strategic Planning, Budgeting and Reporting Manual. The MKUKUTA secretariat has also coordinated development of Multi Sectoral Social Protection Framework.

\section{Research and Analysis Technical Working Group}

The Research and Analysis TWG is responsible for analysis of data, and coordinating outputs of national research that inform policy makers and stakeholders. The main output in 2005-07 was the production of third Poverty and Human Development Report, which included policy briefs in English and Kiswahili. In 2006, the MKUKUTA Status Report (2006) was prepared based on the revised set of MKUKUTA indicators. Other achievements include coordination of Views of the People Study and open policy dialogue sessions where various study findings are shared among stakeholders.

\section{Survey and Routine Data TWG}

The Survey \& Routine Data TWG is responsible for oversight of national data from both surveys and routine administrative sources. The Working Group has developed the Tanzania Statistical Master Plan (TSMP) which seeks to provide strategic directions for accelerating the 
development of statistical capacity and evidence-based policy formulation, planning and decision- making.

In 2005-07 this sub-group conducted a significant number of key surveys, progress is as described below:

Analysis of Agriculture Sample Census (2002/03) is being finalized. A number of outputs were produced including the Crop Report, Livestock Report, Technical Report, Household conditions and Access to natural Resource Report. The printing of Regional Level 2003 Reports for Tanga, Dodoma, Morogoro, Iringa and Mara have been finalized. The remaining 16 Regional reports and other two national Level Reports (Large Scale Farms Report, and Gender Profile of the Agricultural Sector) will be completed by September 2007. The 2006 Integrated Labor Force Survey (including Child Labor and Time-use modules) is ongoing. Other ongoing surveys include:

- Tanzania Service Provision Assessment Survey (TSPA),

- 2007 Household Budget Survey (HBS),

- National Panel Survey (NPS), the survey is still in a design stage,

- Tanzania Disability Survey. Implementation of the above survey is planned for financial year 2007/08. However, planning and preparations have been done,

- Tanzania HIV/AIDS and Malaria Indicator Survey (THIS). Preparatory activities for the THIS survey was done in the 2006/07 financial year,

- 2007 Business Survey,

- Distributive Trade Survey (DTS), The implementation of the DTS started in the 2006/07.

\section{Communication TWG}

The Communication TWG continued with the work of creating awareness on the MKUKUTA framework and on the implications of major findings from MKUKUTA Monitoring System outputs in order to foster dialogue among stakeholders and support the implementation of MKUKUTA.

\section{Progress on Harmonization Initiatives}

In 2006/07 an Inter Ministerial Taskforce on Planning, Budgeting and Reporting comprising of staff from Ministry of Planning, Economy and Empowerment (MPEE), Prime Minister's Office - Regional Administration and Local Government (PMO-RALG), President's Office - Public 
Service Management (PO-PSM) and Ministry of Finance (MoF) was formed. The objective of the task force was to rationalize and harmonise government reporting, monitoring and evaluation approaches.

Notable progress has been recorded in the harmonization agenda including rationalization of planning, budgeting monitoring and reporting processes and dialogue mechanism. For Government institutions, the planning, budgeting, monitoring, and reporting has been rationalized and documented in detailed and user friendly manual called "Medium Term Strategic Planning, Budgeting and Reporting Manual (MTSPBR)" produced by the Government in 2005.

The government will continue with the harmonization of M\&E system in the government institutions for quality reporting and for better decision-making. It will also institutionalize M\&E functions within MDAs and LGAs so as to link it with MKUKUTA monitoring system.

\subsection{Key Issues and the Way Forward}

There are issues that necessitate further actions and dialogue for scaling up implementation of growth and reduction of poverty outcomes. These include further examination and strengthening of linkages between sectors within each cluster for informing cluster level discussions. Furthermore, processes for prioritization, sequencing and checking consistency between the interventions and the MKUKUTA expected outcomes require strengthening. Also, implementation modalities and capacities through community involvement and private-public partnership call for urgent scaling up. Other specific issues include, Economic infrastructure, enhancing agriculture sector performance and promote more agro-processing, exploring alternative sources of energy and rural roads. Other issues are impact of HIV/AIDS, Unplanned settlements in urban centers, attention to vulnerable groups and Human resource crisis, Inclusion of other players in the MKUKUTA implementation report and Monitoring and Evaluation. 


\section{CHAPTER ONE: BACKGROUND AND INTRODUCTION}

\subsection{Introduction}

The MKUKUTA Annual Implementation Report (MAIR) is one of outputs of the Government's monitoring system. The objective of the Government in producing this report is to contribute to the overall Government reporting on progress, including output reporting by MDAs, LGAs and non-state actors implementing MKUKUTA activities. Since both output and outcome reporting are important for the planning process, particularly, to inform subsequent sector decisions, MAIR provides an important overview of progress towards the achievement of the MKUKUTA outcomes.

The MKUKUTA Annual Implementation Report (MAIR) 2006/07 is based on analysis of progress at goal level and provides an overview of performance, challenges, lessons learned, and the next steps within each MKUKUTA cluster. The presentation of the report takes into account inherent complementarities and synergetic relationship among MKUKUTA Clusters. It also includes progress on other processes and reforms, and how these have contributed to achievements of MKUKUTA outcomes. In most areas, reporting is based on information and data on operational targets. Information provided is both quantitative and qualitative. It is also important to note that although the report does not identify the contribution of the non-state actors, the outcomes on the goals should be understood as incorporating those contributions, as for instance, when reporting on the enrolment rates, health outcomes etc. Indeed, there are instances where the role of the private sector is explicitly cited. Performance on cross-cutting issues has been mainstreamed throughout the analysis of the progress made.

\subsection{Coordination and process of Report production}

The broad nature of MKUKUTA as a framework document that moves to an outcome approach beyond priority sectors, and the number of stakeholders involved makes production of an annual implementation report a challenge. The Poverty Eradication Division, in the Ministry of Planning, Economy and Empowerment (MPEE) coordinated the production of MAIR in collaboration with a wide range of stakeholders, including Ministries, Departments, Agencies (MDAs), Local Government Authorities (LGAs), research and academic institutions, as well as Non State Actors (NSAs). The MKUKUTA Technical Committee provided overall oversight.

The preparations involved information gathering from a range of sources, including the implementation reports from MDAs, PHDR, PER studies, the MKUKUTA Status Report 
(2006), Economic Survey, and sector reviews. These reports provided an overview of activities, utilization of resources, outputs and progress on cross-cutting issues. It is important to acknowledge that not many countries produce national reports on outputs and activities that aggregate information from the entire Government. This is in part because of the sheer magnitude of the task that necessitates drawing time away from actual implementation. Instead, countries report nationally only on outcomes, i.e., changes and trends that inform policy and central government actions. It is acknowledged that further strengthening of the links between resource allocation, expenditure and outcome reporting is an important next step in Tanzania.

\subsection{The Purpose, objectives and use of the Report}

The purpose of this report is to inform stakeholders and all Tanzanians (directly or through their representatives -e.g. Members of Parliament) on the progress in MKUKUTA implementation and associated processes, with a view to stimulate dialogue on key issues, and inform subsequent planning, budgeting and implementation. Key objectives and use of the report include, among others, the following:

i. To provide an assessment of progress against Government priorities of economic growth and reduction of poverty as identified in MKUKUTA;

ii. To generate information that will facilitate organization of interventions and priorities in different sectors into a consistent and sustainable implementation strategy;

iii. To stimulate further dialogue and debates among stakeholders on key strategic issues of concern including prioritization and sequencing of interventions, and resources mobilization and utilization in subsequent dialogue processes - as per proposed dialogue structure (PER, GBS, and Sectoral Reviews);

iv. To identify key issues and options for scaling up investment to achieve MKUKUTA goals and targets; and

v. To provide inputs and information for national budget process including the Plan and Budget Guideline and Budget Formulation.

\subsection{Harmonization and alignment of key national processes and MAIR}

The government in collaboration with key stakeholders has pursued harmonization and alignment of key processes on policy planning and budgeting. Harmonization and alignment agenda has also included monitoring and reporting as well as harmonization of external flows with priorities in 
national development objectives. The principles of development partnership relating to harmonization and alignment of aid modalities have been articulated in several documents including: Independent Monitoring Group report, PER Evaluation Reports, Tanzania Assistance Strategy (TAS) and recently in the Joint Assistance Strategy for Tanzania (JAST). The current MKUKUTA Annual Implementation Report takes forward the harmonization agenda, including progress made so far and challenges ahead. It also recognizes the opportunities that are arising from harmonization and alignment of key national development processes.

\subsection{Organization of the Report}

Chapters TWO, THREE, and FOUR present the implementation of MKUKUTA Cluster I, II and III, respectively. Chapter FIVE provides a review of overall fiscal performance and strategic resource allocation. It provides information on resource mobilization, budget preparation, execution, reporting and transparency. It also articulates recommendations for moving forward. Chapter SIX provides a review of the implementation of the monitoring and evaluation process as per the MMMP. It provides information on what has worked and what has not worked. The reasons behind, lessons learned and recommendations for moving forward. The chapter concludes by drawing out key issues pertaining to harmonization with the objective of strengthening reporting on MKUKUTA Implementation using RIMKU. Chapter SEVEN provides a summary of key issues and actions for going forward. It takes on board the achievements, challenges and lessons learned in implementation of all Clusters of MKUKUTA and the Reporting and Monitoring mechanism, financing and resources allocation. The chapter ends by articulating what should be considered during the sector reviews and PER process.

\subsection{Scope and limitations of the report}

Like in all other reporting, it is important that the scope and limitations are clearly spelt out before the reader advances to the subsequent chapters. Since its conception, this work ambitiously wished to report on expenditure, activities, output and on their impact on outcomes. These would have involved detailed presentation of what the government planned to do, the amount of resources committed and used, which activities and interventions that were actually implemented, and what was delivered. It will be noted that MAIR 2007 does not meet all these expectations due to various reasons. One of the outstanding reasons is that, even though budgetary allocation has been aligned to MKUKUTA, the current budget execution reporting is 
not fully aligned with MKUKUTA strategic goals and outcomes. As a result, it is difficult to get budget out-turn information classified according to MKUKUTA. This problem will be significantly reduced with the current budget execution reporting mechanisms (RIMKU, IFMS, PlanRep, etc.) are adjusted to interface with one another. Other areas of limitations related to missing data on some indicators that are generally not produced routinely. The other rare case is in the areas of culture; there the monitoring system is yet to come up with outcome indicators. Nevertheless, in all these cases, activities and processes that have bearings on the areas have been reported. 


\section{CHAPTER TWO: GROWTH AND REDUCTION OF INCOME POVERY}

\subsection{Overview}

This chapter provides an overview of performance under Cluster I of MKUKUTA with regard to major activities, outputs and outcomes. It also presents challenges and lessons learned in the implementation of Cluster I of MKUKUTA, whose broad outcome is to ensure that "broad-based and equitable growth is achieved and sustained". There are six goals under this cluster, each of which has several operational targets. The assessment in this section is organized based on these goals and their respective targets. The premise is the fact that adequate economic growth is a major and necessary condition for poverty reduction as it impacts on the incomes of households (assuming distribution neutral growth) and enables the government to collect more revenues for the provision of social services.

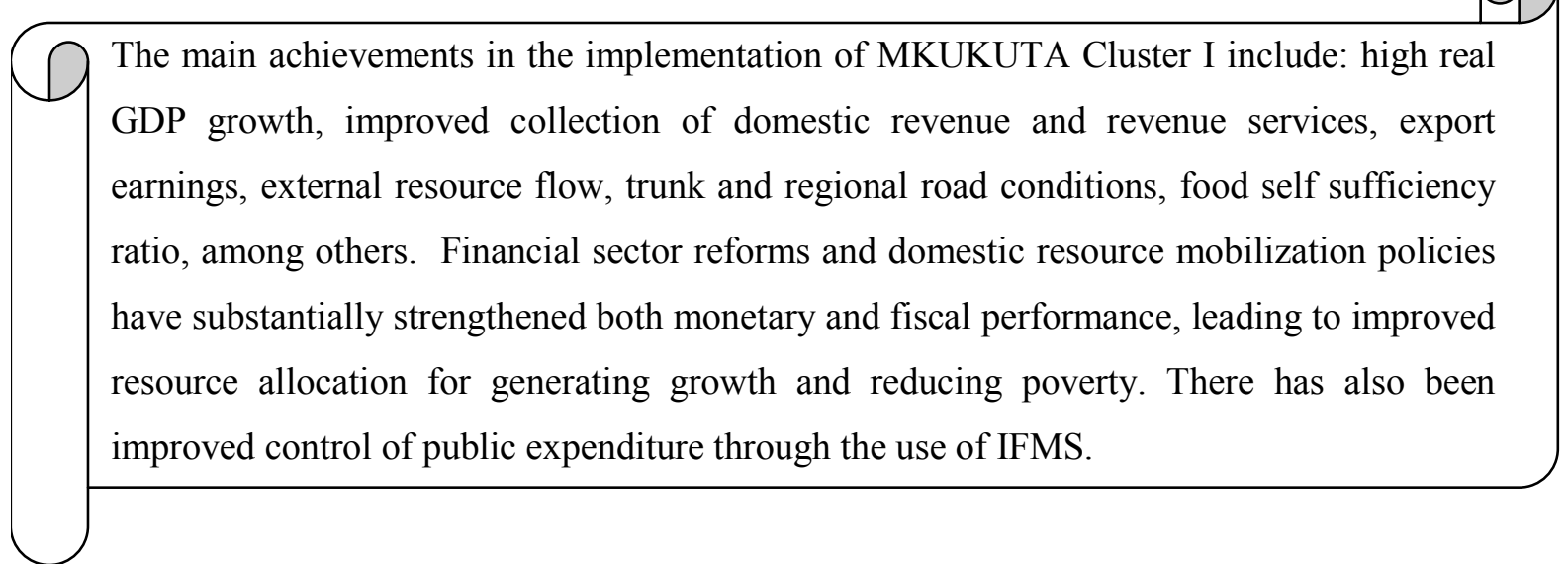

\subsection{Performance and Progress}

\section{Goal 1: Ensuring sound economic management}

The stability of macroeconomic conditions is one of the necessary conditions for sustained and broad-based growth. Under this goal, MKUKUTA has two targets: Maintain Macroeconomic Stability, and Reduction in Unemployment. Operational targets for this goal include (i) inflation rate at maximum of 4 percent, maintaining official foreign reserves of at least six months of imports, achieving debt sustainability (containing the external debt to GDP ratio at 50 percent or less). Consequently, indicators used to assess progress in this goal include annual rate of inflation; Central Government revenue as percent of GDP; fiscal deficit as percent of GDP (before and after grants); external debt service as percent of exports, and export as percent of GDP; and (ii) 
Reduced unemployment from 12.9 percent in 2000/01 to 6.9 percent by 2010 and address underemployment in rural areas.

\section{Performance}

Most macro indicators have recorded positive and significant progress. Total exports of goods and services grew by 6.4 percent to US\$ 3,133.1 million in 2006 from US\$ 2,945.5 million in 2005. The growth was mainly contributed by mineral and service exports (including earnings from tourism). Increase in exports was offset by increase of 28.9 percent in imports because of large import bills for foodstuff and oil. It should be noted that the modest growth in exports is partly due to implementation of Export Development Strategy, which aim at increasing the quantity and quality of Tanzanian exports through processing, enhance investment in the production of export, efficient utilization of opportunities for exports on preferential windows such as AGOA and EBA. Export of services, particularly tourism, increased as a result of government and other stakeholders' efforts in promoting Tanzania as a quality tourist destination.

Revenue Performance: In the fiscal front, domestic revenue collections were significantly above projection despite the drought and energy shocks. This performance is ascribed more to the measures adopted by the Government to mitigate the impact of these shocks on resource mobilization, and efficiency gains in the tax administration. Government domestic revenue collection as a percentage of $\mathrm{GDP}_{\mathrm{mp}}$ (tax and non tax revenue) increased to 15.6 percent in 2006/07 from 14.3 percent in 2005/06.

Foreign Direct Investment (FDI) Flows: During the year under review, there was a slight decline in FDI flows. Nevertheless, Tanzania has also rapidly improved the regulatory climate for private sector development, moving up in the index of Ease of Doing Business ranking from $150^{\text {th }}$ Country in 2005 to $142^{\text {nd }}$ in 2006. Likewise, growth in money supply was within targets. Nevertheless, reforms in the financial sector continued to yield results. Domestic credit to private sector has increased from 11.0 percent of $\mathrm{GDP}_{\mathrm{mp}}$ in 2005 to 12.5 percent in 2006 , which is a 1.5 percentage increase slightly higher than MKUKUTA target of one percent per annum.

Annual rate of Inflation: The fiscal and monetary policies were in line with MKUKUTA, even though some of the indicators failed to match the targets. In particular, the inflation rate in the year to June 2007 was 5.9 percent, which is above the target of 4 percent per annum. The failure to achieve this target is partly attributable to (i) the drought which affected the production of food crops, hence the increase in the food prices, and (ii) the increase in the petroleum price. The later 
led to increased costs of transportation and of the generation of thermal electricity, and consequently, production costs. The government continued to implement sound monetary policy to ensure that the creeping inflation does not get out of control. The policy is reflected in pushing down the growth in money supply. In 2006, broad money supply (M2) grew by 13.5percent compared to 36.9 percent in 2005 . Growth in the extended money supply also decreased during this period.

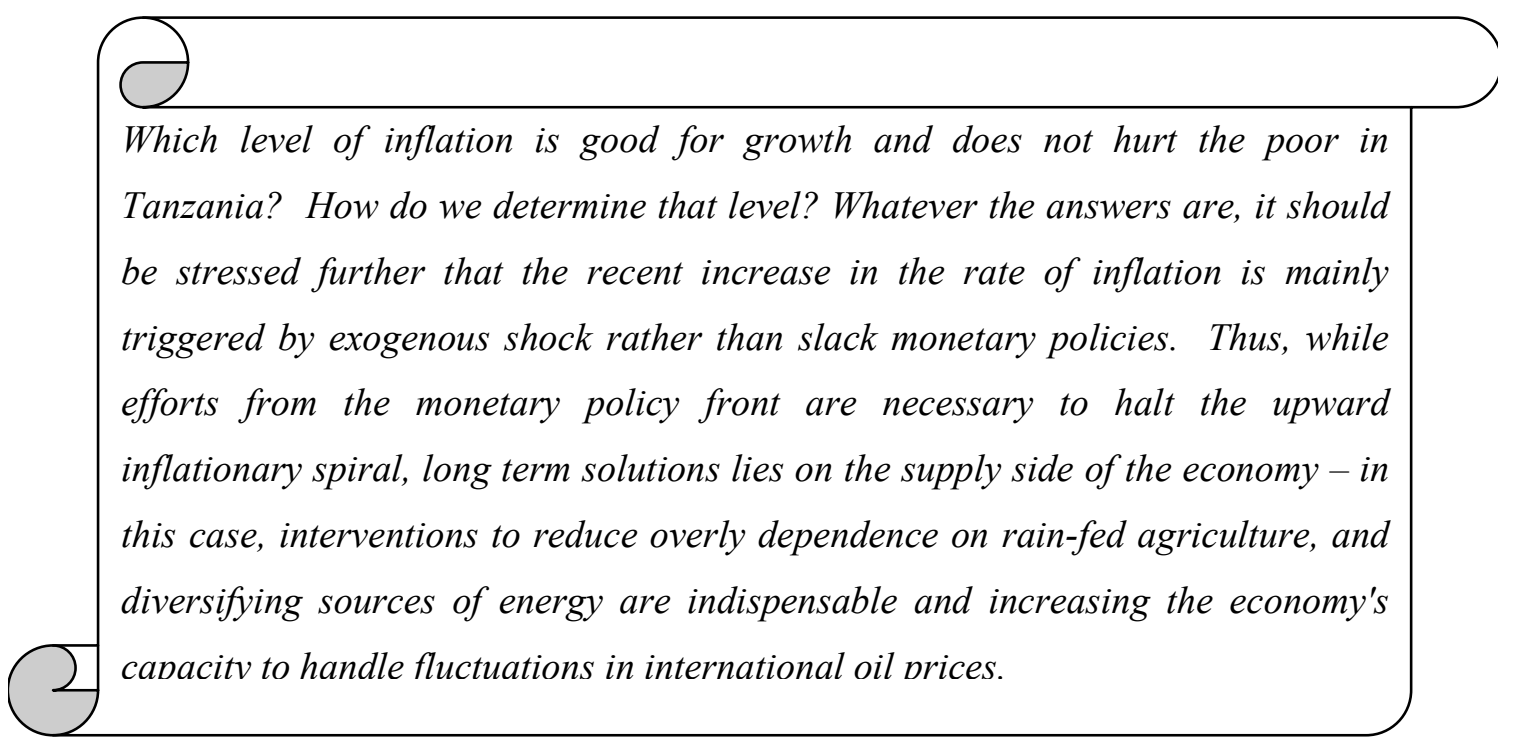

National debt: With regard to this indicator, significant achievement has been recorded in the recent years. The external debt stock in the year under review was estimated at US\$5,749.0 or about 35percent of GDP compared to 50 percent of GDP as MKUKUTA requires ${ }^{1}$. Both external and domestic debt stocks declined, but it is noted that the external debt declined faster mainly due to debt relief obtained under the HIPC, MDRI, Paris Club members and some non-Paris Club members. Consequently, debt service as percentage of exports of goods and service declined from 4.4 percent in 2005 to 2.3 percent in 2006 . The total external debt is equivalent to 80.0 percent of the total national debt stock. With the objective of avoiding slippage into the debt trap, the government now borrows only on concessional terms as stipulated in the National Debt Strategy. Such loans are directed to capacity building, investment promotion and employment generation, improving government domestic revenues, export promotion, infrastructure and human resource development.

\footnotetext{
${ }^{1}$ GDP of US\$ 16,520 mil. at an exchange rate of TShs 1250/US\$
} 
Official foreign reserves: As of 2006/07, official reserve has been equivalent of 5.3 months of import as compared to 6 months of import in the year before. Three major reasons explain the decline: (i) increased import bills caused by increased petroleum prices, (ii) an increase in the importation of capital goods and (iii) increases in the importation of foodstuffs in response to the drought. As noted, the trend in export earnings as percentage of GDP is however on the increase despite marginal decrease from 22.2 percent in 2005/06 to 21.9 percent in 2006/07. The reserves were also used to ensure stable macroeconomic conditions. The period under review experienced a slight depreciation of Tanzanian Shilling. To ensure stability in the Shilling market, the government through the Bank of Tanzania has been intervening to iron large swings in the value of Shillings again major currencies.

Unemployment: MKUKUTA targets to reduce the problem of unemployment to 6.9 percent by 2010, from 12.9 percent in 2000/01. The results of the Integrated Labor Force Survey (ILFS) 2006 reveal that the rate of unemployment was 11 percent in 2006. The unemployment problem is more acute in Dar es Salaam where the rate is 31.4 percent. The rates in other urban areas and rural areas are 16.3 percent and 7.1 percent respectively. Variations are also noted across gender and age groups; the rates are higher for women than for men and for youth than for older age groups. Unemployment in general was more severe among urban women and the youth of $15-$ 24 years of age because majority of them enter the labor market for the first time without any work experience or skills.

The survey further shows that the active population (labor force) has risen to 20.6 million, from 17.8 in 2001/02, which represents an average annual increase of 760,000 in the labor market. In FY 2005/06, out of the 18.3 million employed people, 76.5 percent were in agriculture, compared to 84.2 in $2000 / 01$; 9.3 percent were in the informal sector against 5.3 percent in $2000 / 01 ; 8.0$ percent were in the private formal sector as compared to 2.4 percent in $2000 / 01 ; 3.5$ percent were in domestic work compared to 3.1 percent in $2000 / 01 ; 2.4$ percent were in the government compared to 2.2 percent in $2000 / 01$; and 0.4 were in parastatals compared to 0.5 percent in $2000 / 01$. 
The employment trends highlight several important issues: (i) employment in the public sector has increased both in relative and absolute terms, (ii) there is significant shift away from agriculture, (ii) correspondently, and there are significant increases in the informal sector employment and other private sectorsupposedly formal. Further information indicated that, as of December 2006, about 201,000 new employment opportunities were recorded from various sectors. The private sector is leading in producing new employment opportunities. A

Several interventions were undertaken to boost labor absorption capacity of the economy. Labor Based Technology Unit under the Appropriate Technology Advisory and Training Project (coordinated within the Ministry of Infrastructural Development) became fully operational. This is expected to increase job creation through the road constructions. Furthermore, a total of 27,244 enterprises were given loans countrywide through National Empowerment Funds for the purpose of reducing unemployment and income poverty. Also, the government continues to strengthen and expand the Labor Exchange Centers. A new Cross-Border Placement Services Section has been established in the ministry responsible for labor to oversee labor movements.

Along the same lines the National Service continued to create employment opportunities to Tanzanian youths through provision of the initial training in artisan skills and life skills, and vent them with the values of self reliance. The program has also indoctrinated the youth with fundamental Tanzanian values; including issues of patriotism and national cohesion which are indispensable to the stability and prosperity of Tanzania.

Lastly, the defense forces have continued to protect the sovereignty and security of the United Republic of Tanzania and safeguarded national interests. This has not only continued to bring peace, tranquility and prosperity but also functioned as a basic framework for the stability and socio-economic development of the nation at large.

\section{Goal 2: Promoting sustainable and broad based growth}

The second goal has 11 operational targets that can be used to assess the implementation. However, some of these indicators are not generated from routine data and could not be obtained 
at reasonable frequencies. However, several processes are noted, which have a bearing on the operational targets. These are presented subsequently.

\section{Performance}

GDP Growth: The target is to have annual real GDP growth between 6-8 percent. The implementation of ongoing reforms in the country has yielded substantial economic growth, as exhibited by good macroeconomic performance over the past seven years, whereby real GDP has been growing at an annual average of 6.0 percent, which is above the Sub-Saharan average. This performance is higher when compared to the annual average growth of less than 5 percent in the late 1990's. Growth performance is still on track although it slackened slightly to 6.2 percent in 2006, compared to 6.7 percent attained in 2005. The decline is mainly attributable to drought and energy crises. Agriculture, manufacturing, electricity and water sectors were the most hit by the crises.

Growth in Manufacturing Sector: Growth in manufacturing sector is poised to increase from 8.6 percent in year 2000 to 15 percent by 2010 . However, it registered 8.6 percent growth in 2006 compared to 9 percent in 2005. As noted earlier, the decline again is explained by power crisis which increased the cost of electricity as well as the increase in the price of industrial oil. Conversely, the contribution of the sector to GDP rose from 9 percent to 9.2 percent from 2005 and 2006 respectively. The manufacturing sector is among other sectors of the economy next to agriculture in terms of employment creation.

Progress has so far been noted in other interventions in the agro-processing sector. During the year under review, 4,280 new jobs were created in 61 newly licensed crop-processing firms between January 2006 and June 2007. This is relatively a large number in the labor market analysis of small economies like Tanzania. Similarly, under the National Service programme during FY 2005/06 and 2006/07 a total of 3,374 and 2454 youths were provided with the initial training in artisan skills as well as other related life skills. 
Growth in Agricultural Sector: Agricultural sector is targeted to grow from 5 percent to 10 percent by 2010. However, it grew by 4.1 percent in 2006 due to drought. The crop sub-sector grew by 4.0 percent in 2006 compared to 5.2 percent in 2005 .

Over the recent past, growth in the agricultural sector has improved but is still relatively lower than the overall growth in the national economy. Large part of the agricultural sector still uses poor technology partly due to low access to credit. Findings from the Agricultural Sample Census Survey in 2002/03 revealed that only 3.0 percent of total small holder area was under irrigation and only 3.0 percent of small holders accessed formal credit for agricultural purposes. To alleviate this problem, the government has put in place several interventions, such as expansion of irrigation schemes and provision of agricultural credit and inputs to small holders.

The Agricultural Sector Development Program (ASDP), is a program that is implemented through District Agriculture Development Plans (DADPs), Agriculture Marketing Systems Development Program (AMSDP), District Agriculture Investment Project (DASIP), Participatory Agricultural Development and Empowerment Project (PADEP). These are interventions in place aimed at improving agriculture sector development in the country. Nevertheless, the incidence of drought in 2006 revealed the extent to which agricultural production is still vulnerable to weather conditions.

Agreeably, the solution to this challenge is to increase area under irrigated agriculture. In 2006, an irrigated area of 9,557 hectares was developed, compared to 14,396 hectares which were developed in 2005 . This has made the area under irrigation to be 273,945 hectares compared to 264,388 hectares during the period under review. The increase was a result of construction and rehabilitation of 111 irrigation schemes in various parts of the country.

Another set of interventions in the agricultural sector include government subsidies in fertilizers, pesticides, and improved seeds. With regards to improved seeds and fertilizers, about 89,941 tones of fertilizers procured under the subsidy arrangement were sold to farmers in 2006/07. This intervention partly explains the increase in agricultural production in areas that were not severely hit by the drought. However, there are complaints that the current arrangement scheme benefits the middle business-persons more than the target smallholder farmers. 
Growth in livestock sub-sector: Like in the crop sector, drought affected the livestock sector. In 2004 growth rate was 4.8 percent compared with 2006 which was 4.1 against MKUKUTA targets of 9percent by 2010. Besides drought, livestock contribution also suffered from outbreak of Rift Valley Fever (RVF). The outbreak caused a significant decline in consumption and trade of livestock and livestock product as a whole. It is worth noting that in order to faster the development of the livestock sub-sector, the government has prepared a livestock policy of 2007 and enacted the Meat Industry Act. No. 10,2006. This law became effective in May 2007. The government is in the process of drafting the Animal Welfare Bill and the Hides and Skins Bill. Currently the government continues to implement livestock components of ASDP.

Mining Sector: MKUKUTA target is to increase export proportion of value added minerals from 0.5 percent to 3.0 percent by 2010 . So far there are no data for the indicator, but it is noted that growth in the mining sector, including quarrying, increased by 0.7 percentage point from 15.7 percent to 16.4 percent in 2006. The contribution of the sector to GDP only increased from 3.5 percent in 2005 to 3.8 percent in 2006. The increase comes from both large and small scale miners.

It was further noted that the value of mineral export increased by 15.8 percent in 2006 to US\$ 823.9 mil from US\$ $711.3 \mathrm{mil}$ in 2005 , but mainly due to increase in the price of gold in the world market. During the same year the volume of gold export declined by 11 percent to 42.7 tons, which together, implies there were little improvements in the value addition through processing. In order to increase value addition to Tanzanian minerals, the government completed the process of upgrading Gemstone Carving Center in Arusha. The upgrading aims at making this a training center for jewelry and gemstone crafts. Furthermore, the government has completed the establishment of Mining Cadastre Information Management System. This system provides data location, ownership, and estimated mineral potentials.

Scaling-up the informal sector: Scaled up participation of the informal sector and SMEs (including cooperatives) in the mainstream economy, is one of the operational targets under this current goal. The results of the ILFS 2006 indicated a substantial increase in the share of labor force employed in the informal sector - from 5.3 percent in 2000/01 to 9.3 percent in $2005 / 06$. The government continues to promote the sector using various instruments such as informal sector exhibition for East African Countries, and demand driven skills programs. In the small scale (informal) mining sector, the government approved the plot demarcation for 4,1666 licenses 
of artisanal miners under the new licensing arrangement out of 5,800 licenses issue under the older arrangement. Also in the period under review, 549 new licenses for small scale minors were issued.

Road Sector: MKUKUTA targets to repair 15,000 km of rural roads annually by 2010 from $4,500 \mathrm{~km}$ in 2003 . The quality of rural roads remains low. There is some progress on the Council roads, whereby $13,353 \mathrm{~km}$ of roads were scheduled for rehabilitation. By April 2007, a total of $3,181 \mathrm{~km}$ of council roads has been rehabilitated. The persistent under performance demonstrates how daunting the task is, and the target may have been too ambitious.

Notable progress has been registered in the trunk and regional road sector, whereby the percentage of trunk and regional roads in good and fair conditions increased from 51 percent in 2000 to 78 percent by December 2006. For the fiscal year under review, the following developments were made. In the national/trunk road category, $318 \mathrm{KM}$ tarmac roads were constructed; $78 \mathrm{Km}$ of tarmac roads were rehabilitated and $153.5 \mathrm{KM}$ of gravel roads were rehabilitated. In the category of regional roads, $368 \mathrm{~km}$ of gravel roads and $15 \mathrm{~km}$ of tarmac road were rehabilitated. The preliminary result from the 2007 HBS indicates that the developments in the road sector have increased market accessibility. To further improve the road sector, the government completed the preparation of Transport Sector Investment program (TSIP). One of the goals of the program is to ensure that all national (trunk) roads are paved (tarmac) by 2018.

Impact on environment: land and biodiversity: The second goal in Cluster I have two operational targets that relate to environmental issues. These are: Reduced negative impacts on environment and peoples' livelihoods and reduced land degradation and loss of biodiversity. The government continued using various command and control policy instruments to protect the environment. One of the major interventions was short-term ban on trade of exporting logs, sandalwood, charcoal and sleepers. Partly due to this measure, there was a decline in logging activities. During 2006, a total of 5,117,063 cubic meters of logs were harvested, compared to $5,867.48$ cubic meters in 2005 . The government also used market based as well as command and control instruments to safeguard the environment such a ban on the use of plastic bags with thickness not exceeding 30 microns.

Several other processes related to this goal include, formulation of action plan for implementation of Environmental Management Act; drafting of regulations related to land management including tree planting, and establishment of Village Land Forest Reserves. Others include regulations on 
Environment Impact Assessment, environmental inspectors and registration of environmental experts. The government also established Environmental Grant under Urban Development Program to support initiatives on environmental conservation. Furthermore, the government continued to support Participatory Forest Management initiatives in 29 districts in eight regions. Similar interventions in the protection and management of catchment forests and mangroves have shown clear gains in the Eastern Arc and Coastal Forest eco-region. Through these interventions, communities living adjacent to natural resources continue to enjoy the benefits such as fuel wood, fishing, eco-tourism, and hunting. Besides, communities play their role in management of natural resource through Wild Management Areas, Beach Management Units, Community Based Forest Management and several development projects.

Presently, there is improved environment regulatory framework in place, for example, Strategy for Urgent Actions on Land Degradation and Water Catchments (SUA-LWC). Under SUALWC, measures taken to protect the environment include eviction of people from Ihefu basin/valley. This has led to restoration of natural vegetation in the area, increased water flows to the Ruaha River, and consequently, water level in the Mtera dam. Further efforts are required to improve environment management across the country, and particularly at district and community level.

\section{Goal 3: Improved food availability and accessibility at household level in urban and rural areas}

Ensuring food security is at the heart of poverty reduction. MKUKUTA operational targets under this goal are specified as follows:

- Increased food crops production from 9 million tons in 2003/04 to 12 Million tons in 2010.

- Maintained Strategic Grain Reserve of at least 4 month of national food requirement

\section{Performance}

With respect to the first target, in 2005/06 food crop production reached 10.9 million tones. This resulted in food Self Sufficient Ratio (SSR) of 112 percent which is in line with MKUKUTA targets. Projected food production in 2007/08 will result in SSR of 109 percent. 


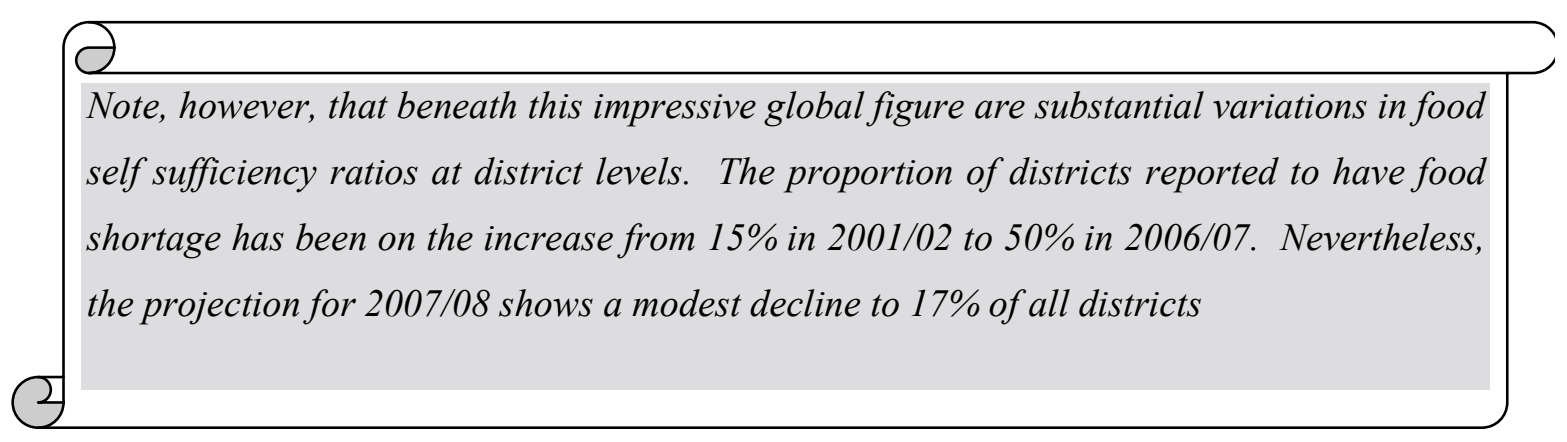

The overall national food self-sufficient ratio in Tanzania is satisfactory but the challenge has been on the distribution modalities of foodstuff from surplus districts/regions to those with food shortage. Five regions, Tabora, Singida, Kilimanjaro, Arusha, and Dar es Salaam, are projected to have food shortage due to inadequate harvests in these regions. Partly, in response to these projections, during the year under review, the SGR purchased and stocked 27,500 tones of cereals. However, this stock volume is rather low compared to MKUKUTA targets of SGR stock of 4 months of national food requirement.

Several processes and activities aimed at improving the state of food security have been implemented. These include four major food production and situation surveys, training on post harvest management technologies for food crops, radio and TV programs for the same, and drafting of the National Food Security Strategy. Furthermore, the government continued to strengthen data collection and analysis on weather and food situation in order to be able to predict and give early warning on imminent shortage in food production. Also, there has been substantial expansion in the areas under irrigation in order to reduce direct dependency on rain-fed agriculture.

Goal 4 \& 5: Reducing income poverty (Urban and Rural)

\section{Performance}

Reduction in Food and Basic Need Poverty: The basic indicators here require HBS data (or similar surveys). Although HBS 2006/07 is underway, the lack of concrete poverty measures in 
the intermediate years between two successful HBS is a challenge that can only be solved if more frequent data - in panel data surveys, are collected. Even with absence of household budget survey since 2001, relatively high GDP growth points to possible improvement in income poverty even when such growth is associated with some modest increase in inequality. In the absence of HBS data, growth in the agricultural GDP has been used crudely to indicate reduction in rural poverty. As noted earlier, agricultural GDP grew by 4.1 percent in 2006 against the targets of 9 percent by 2010. Given the population growth rate of 2.9, it implies that per capita income in the rural areas only increased by 1.2 percent which would have only marginal effect in the reduction of income poverty.

The government recognizes that low incomes of the farmers partly are attributable to lack of marketing policy. To improve the incomes of the farmers, the process of drafting the agricultural marketing policy has started and planned to be completed in 2007/08. Several other interventions have been implemented through various programs to boost incomes of the rural and urban dwellers. These interventions include Rural Financial Services Program, National Entrepreneurship Development Funds, Rural Micro, Small and Medium Enterprises Support Programme commonly known as Muunganisho wa Ujasiriamali Vijijini (MUVI) coordinated by MITM through SIDO, and some components of TASAF II, etc.

MKUKUTA recognizes that natural resources, like forestry and fishery, form part of sources of incomes in many areas. These sources have been recommended for assessing progress in the reduction of income poverty in rural areas. For the period under review, beekeeping has been by and large successful in achieving positive impact. Interventions in this area have included intensive training in best practices. Furthermore, in 2006/07 some community based organization (CBOs) have been contracted to manage resources in their areas. Also, about 90 district licensing committees were facilitated to undertake forestry harvesting plans countrywide.

In general, the government continues to enforce several legislations such as Environmental Management Act, Forest Act, Beekeeping Act, Fishery Act, and Wildlife Act in order to protect the environment and conserve the natural resources. The impact of legal and regulatory framework and reforms has been positive and identified policy gaps have been addressed through Forest Regulations and various guidelines. Gaps remain, however, regarding the sharing of forest revenue in participatory forest management (PFM) arrangements. 


\section{Goal 6: Provision of reliable and affordable energy to consumers}

There are two operational targets for this goal:

- Liberalization of the power sub -sector effected by 2010.

- At least three (3) Production Sharing Agreements (PSA) negotiated, concluded and signed by June 2010 .

\section{Performance}

There is a significant improvement in this area. Three PSAs were negotiated and concluded from January to August 2007. This makes 19 PSAs so far concluded and operational by the end of August 2007. There was also an establishment of a website for information on petroleum existing and potential stocks. This will facilitate prospecting companies in petroleum industry. Despite this progress, the year 2006 was a particularly difficult year for the energy sector as it was characterized by power shortage and high price of crude oil and petroleum products. The growth rate of electricity sub-sector declined to -2.5 percent in 2006, compared to 5.3 percent in 2005 . Power generation had to be shut-down at the main hydropower plants of the country. The subsequent effect was a severe electricity shortage, whereby hydropower generation dropped from $561 \mathrm{MW}$ in 2005/06 to $260 \mathrm{MW}$ in 2006/07. As a result of the serious electricity supply deficit, the Government started load-shedding program. The drought and subsequent energy crisis was compounded by hiked oil prices during the year.

In response to the electricity crisis, several measures were taken that are likely to have medium to long term effects. These measures include implementing emergency power generation projects; conducting a feasibility study on seismic data to establish availability of gas and petroleum; strengthening government collaboration with the Artumas Company and drilled two exploratory wells at Mnazi Bay (Mnazi Bay 2\&3) in Mtwara Rural District. Furthermore, the government has finalized drafting of rural electrification master plan, signed two agreements for the production of electricity, and secured funds for electrifying the remaining district headquarters.

\subsection{Status and Progress of Sector Review}

Sector reviews were instituted to enhance sector performance in addressing their respective strategies and plans. These have continued during MKUKUTA implementation, to put in focus 
outcomes of growth and reduction of poverty. MKUKUTA recognizes the roles and importance of existing specific sector development strategies and or reform programs as they contribute directly towards attainment of the desired goals and targets. Thus, it is important to note that sector reviews undertaken in Cluster I and II and reforms being carried out in Cluster III have had significant contributions to achievements made so far.

The rationale of the sector review, whether it appears in this or the next chapter, is based on the premise that, within a government-led reform process where multiple stakeholders are involved, accountability and management objectives would be served by a transparent, reliable and agreed mechanisms with which to asses achievements and evolution within the sector. These therefore remain key element for informing prioritization and improving efficiency and effectiveness of resource utilization. Thus, specific objectives of sector reviews include among others:

- To provide a deeper understanding of the critical linkages between the various sub sector policies, strategies, plans, laws and regulations

- To identify major achievements and gaps, issues and challenges that pose threat to bringing about desired changes in the sector

- To focus on the problems and implications of planning and budgeting for the sector as a whole and to provide recommendations

- To discuss how various stakeholders can contribute to effective policy dialogue with Government

- To discuss how progress in various sectors can be more effectively monitored in line with MKUKUTA's outcome based approach

- To provide inputs that will guide the processes towards specific sector policy guideline and strategic plans.

Regarding sectors addressing issues under MKUKUTA Cluster I, a number of activities and processes took place during the review period as part of the implementation of MKUKUTA. These include preparation for the sector reviews (Transport, Roads and Communication, energy and agriculture).

Transport Sector Review: A number of activities and processes took place during the review period as part of the implementation of MKUKUTA. Preparation for the sector reviews (e.g. Joint Infrastructure Sector Review- Transport, roads and Communication) that will take place in September, 2007 was finalized. Furthermore, the government has finalized the preparation of 
Transportation Infrastructure Investment Program (TSIP) covering all sub sectors, including local Government and crosscutting issues. TSIP has been prioritized and aligned with Medium Term Expenditure Framework 2007/08 - 2008/09. In strengthening the legal framework, Roads Act 2007 was approved by the Parliament in April 2007 and preparations of regulations for implementation of this act is in progress. TANROADS has continued to improve its performance as reflected by its improved absorptive capacity, maintenance performance and road conditions. The government has adjusted the fuel levy in June, 2007 to generate more resources for existing road network maintenance.

Energy Sector Review: With respect to Energy Sector Review including delivery of Power Sector Reform Strategy, preparation is at advanced stage. Review of the report by stakeholders is scheduled for October 2007. Furthermore, Progress has been made in formulating the Power Master Plan (costed and prioritized) which aims at addressing, among other things, rural electrification problems. The government is also making progress in the implementation of the TANESCO financial recovery plan and governance, including a study on standardized Power purchase Agreement and Tariffs for off-grid renewable energy schemes as well as drafting of electricity Act.

Agriculture Sector Review: The agriculture Sector Lead Ministries (ASLM) conducted an Agriculture Sector Review (ASR) in 2006. The last ASR was prepared. The aim of the 2006 ASR was to review the major changes in sector policy and institutions as well as the performance of the agriculture sector in the country during 2001 - 2005. The review came up with important findings with regards to sector policy and institutions, which need to be addressed in future plans. With regards to sector performance during 2001 -2005, the ASR showed that the agriculture sector has been growing at an average annual rate of almost 5 percent and has been on the rising trend since 2000. The annual aggregate economic growth rates have been significantly higher than the average annual population growth rate of 2.9 percent, leading to positive poverty reduction. Also private sector investments in agriculture sector have been gradually expanding at a relatively high rate, leading to the sector's increased share in total private sector direct investment (in value) in the country and increased job creation. At the end, the ASR recommended the following strategic options for improving further the sector's performance:

- Improving producer incentives;

- Developing new sources of agriculture growth;

- Increasing farm productivity; 
- Improving agribusiness and processing;

- Enhancing participation of rural poor in agriculture growth;

- Improving agriculture sector investment climate; and

- Improving public expenditure management in the agriculture.

Furthermore, a number of initiatives have being taking place over the recent past to improve agricultural sector delivery. These include preparation of Draft National Food Security Strategy, preparations for the Agriculture Sector Review (including PER and performance review of ASDP) as well as amendments of legislation for all crops boards. In order to expand the understanding of the problems of food security and recommend solutions, special studies on SGR, input Trust Fund and input subsidies were conducted. The government has also prepared a draft of Agricultural Extension Implementation Guideline, which will enhance the efficient in the provision of extension services by state and non-state actors.

The National Employment Policy (1997) has been revised to address the new challenges related to persistent under or un-employment, globalization, and dynamics in the regional labor markets. The government has also formulated the National Employment Creation Strategy and Program to ensure that target of creating 1,000,000 new jobs by 2010 is reached. Furthermore, preparations have started to develop the Employment Promotion Service Bill (2007), as well as review of National Labor Law Phase II. Implementation of Labor Law Reform Phase I have also started.

The government is implementing the second generation financial sector reforms in the context of the Financial Sector Reform Implementation Action Plan (FSIAP). The plan and action matrix, which identifies key actions and the corresponding development partner support in each of the nine major areas of reform, have been formally adopted by the government in March, 2007. Laws governing the operations of the Bank of Tanzania and other Banking and Financial Institutions have been revised in order to make the financial sector more efficient and responsive to current financial development. The review is also aimed at enchasing the banking supervisory role of the Bank of Tanzania to ensure stable macroeconomic environment and sustainable economic growth. Furthermore, proposals for draft Leasing and Mortgage laws are currently being discussed by stakeholders with the intention of presenting to the Parliament. These laws are expected to provide opportunities for the public to access loans for leasing and housing and consequently boost the real estate development. 


\subsection{Challenges}

Notable progresses have been made in achieving and sustaining broad based and equitable growth in the last two years. However, significant challenges have been experienced in the period under review. Main challenges ahead include translation of achievements at the macro level, into sustainable development at the grassroots level. The question is how the gains from growth can be transmitted to poor households. There is still a need to strengthen mechanisms (policies legal frameworks, institutions etc) at the meso level to be able to facilitate responses at the micro level.

Tanzania's economy is still dependent on few exports and export earnings have not been increasing significantly. This could be explained by failure to realize export opportunities in the international market. Available opportunities for export markets including: EBA, GSPS (China and Canada), AGOA and EPZs ${ }^{2}$ have not been utilized fully. Therefore, there is a need for diversification of exports commensurate to international market standards. As regards to export of services, the challenge is to improve services, through expansion of tourist attractions and improvements in associated infrastructure, such as ports, roads and railways. Low export earnings as compared to import bill have resulted into significant negative trade balance.

Energy is a central impetus for production activities; however, in the last two years Tanzania experienced low and unreliable supply from hydro sources. There is therefore a need to reduce dependency on hydro energy by developing alternative sources of electricity. A related challenge is that of reaching the rural dwellers, at reasonable and affordable cost.

The rate of economic growth is still low when compared with the target set in MKUKUTA. The current rate of growth, though higher compared to previous years but can not substantially lead to poverty reduction, especially considering the population growth rate of about 3 percent per year. Accelerated economic growth is needed in order to enhance domestic resource base and improve government ability to provide public services.

The challenges to rural growth are largely related to those in the agricultural sector, including rain-fed dependency, low productivity of land and labor inputs; underdeveloped irrigation potentials; limited capital and access to financial services; inadequate agricultural technical support services; poor rural infrastructure hindering effective rural-urban linkages; infestations

\footnotetext{
${ }^{2}$ EPA as a market access opportunity is yet to be realized. Negotiations are still on going until December, 2007. Likewise, SEZs are yet to be realized as a market opportunity.
} 
and outbreaks of crop and animal pests and diseases; erosion of natural resource base and environmental degradation; weak producers' organizations as well as poor coordination and limited technological capacity.

In the labor market front, expected free movement of labor among East African member states also poses a challenge as well as new challenges of globalization facing our country. More research is needed on the issues of employment, including research on youth unemployment.

Harmonization is still lacking in many sector policies, e.g. Employment vs. Trade, Investment, Finance and Educational policies. Other areas include Labor vs. Privatization, and policies that are aimed to attract more foreign investment. Thus, more review of these laws is needed to harmonize them and ensure consistency.

In the area of environment and natural resources conservation, less gains has been reported in southern highlands, miombo forest in Tabora and southern Tanzania. It has also been noted that the impact of the development of forest based industries and sustainability of livelihoods have been limited, partly due to substantial under funding and lack of mechanisms or studies to capture the private sector contribution in the implementation of National Forest Program. It is further noted that increases in revenue collection from the natural resource sector comes from impounding and sales of illegal harvests of natural resources.

\subsection{Way forward}

There is a need to adopt agriculture policy that is geared towards small-scale low productivity farms as part of poverty reduction strategy as opposed to an agricultural growth per se. This will involve developing viable full-time small-farm activities including a combination of subsistence and market production. Consistent with this, a revitalized commercial agriculture should be promoted to increase employment and reduce rural poverty directly by absorbing wage labor and indirectly via growth of the downstream processing industry.

Along the same line, efforts are still needed to increase productivity in the agriculture in order to have reasonable impact on the reduction of rural poverty. Thus, there is a need to improve the flow of market information and speed-up the response of the private sector in taping from these opportunities (through say, Agricultural Marketing Systems Development Program (AMSDP)). 
Also, effort needs to be directed to improve on the availability, distribution, and affordability of agro-inputs and extension services as well control pest and diseases.

Effort to encourage rural non-farm activities should be scaled-up since these are promising areas for increasing rural employment, especially in the food processing and service sectors, and thus reduce poverty. This strategy can work in areas that are better served by roads, electricity and communications i.e. where factor and product markets work better and transaction costs are lower. The government should thus ensure the critical ingredients to stimulate the development of a vibrant rural non-farm economy (education levels and basic infrastructure) are improved.

The Government should increase the pace of implementing the second generation financial sector reforms so that the sector can continue to support economic growth through provision of adequate and affordable financial services.

Another critical area is the diversification to other sources of energy. The way to accelerate achievement of this goal is through promotion of regional cooperation in the energy sector, implementation of the PSMP.

In the area of employment, there is a need for implementation strategy for Youth Development Policy, National Employment Policy, and National Social Security Policy. These will enhance creation of employment opportunities as well as enabling environment for self-employment. With respect to public financial management the focus should be on:

- attaining and sustaining sound financial management and accountability;

- $\quad$ improving resource mobilization, allocation, and utilization .

There is a need to facilitate the provision of services required to improve the production and productivity in the livestock sector as well as ensuring reliable domestic and external markets for livestock products. In the international front, there is a need to speed up effort in implementing the national foreign policy where focus is on economic diplomacy in terms of attracting foreign markets, foreign investors, as well as negotiating for low interest loans and debt cancellation.

In the area of environmental and natural resources, effort would be directed to cub illegal harvesting, improve governance in the sector, scaling-up tree planting initiatives, enforcing revenue collection targets, and strengthening Forest Surveillance Unit. Other areas include more 
support in data collection and analysis regarding the contribution and sustainability of the natural resources.

This chapter has provided an overview of performances, challenges, and lesson learned in relation to economic growth and reduction of income poverty. So far the government has made major strides in putting the economy on higher and sustainable growth path. This has a bearing in improving the social wellbeing and quality of life. In the medium to long terms, improved quality of life and social wellbeing (in terms of better education, health, nutrition, etc.) have a feedback loop to growth. Issues of social wellbeing and quality of life are discussed in the next chapter. 


\section{CHAPTER THREE: IMPROVED QUALITY OF LIFE AND SOCIAL WELBEING}

\subsection{Overview}

The previous chapter has presented evidence of high economic growth and stable macroeconomic

performance. Such environment is necessary for the improvement in quality of life and social wellbeing through increased households' resources. More so, high economic growth and overall macroeconomic stability enables scaling-up government interventions due to increased fiscal resources from domestic revenues and various kinds of support from development partners. This chapter assesses the performance under cluster II of MKUKUTA with regards to major activities, outputs and outcomes. It assesses the achievements, challenges, and lessons learned. It then provides future plans. The chapter ends by assessing progress of the key reform processes that have a bearing on achieving outcomes envisaged in quality of life and social wellbeing.

The broad expected outcomes under this cluster focuses on the poorest and most vulnerable as well as inequalities (e.g. education, survival, health) across geographic, income, age, gender and other groups. It is apparent that apart from addressing issues of access and equity in basic social services, the ultimate outcome that emanates from targeted goals is the build-up of the nation's human capital. Promoting human capital development is critical in reducing poverty. This is strongly evidenced by the synergies and linkages that exist between poverty and poor quality of basic social services such as low level of education, poor health and nutritional status as well as poor quality of water and sanitation services. It is for these reasons that the government is committed towards improving access and quality of basic social services for improved quality of life and social wellbeing.

\subsection{Performance and Progress}

Goal 1: Ensuring equitable access to primary and secondary education for boys and girls, Universal literacy among men and women and expansion of higher, technical and vocational education

The overriding objectives of MKUKUTA for this goal seeks to address early childhood development, increased enrolment, and opportunities for children with disabilities, improve 
learning environment and access to and quality of education, adult education, and improvement and expansion of vocational and higher education.

The government recognizes the importance of education in enhancing poverty eradication initiatives in the country. It is thus fully committed towards expanding access to and quality of education at all levels but with a focus on basic and secondary education. That is why it appreciates the fact that expansion in educational facilities and access should move hand in hand with the maintenance of quality of education delivered at various levels. Thus, during the period under review, the government continued with implementation of several programs in education sector. Notable ones are Primary Education Development Program (PEDP), Secondary Education Development Program (SEDP), MEMKWA, Tanzania Education Alternative for Children (TEACH), etc. Furthermore, in a bid to address gender imbalance in accessing secondary education, the government continued to implement the Girls Secondary Education Support Project (GSES), which aims at assisting the education costs for girls from poor families.

As a result of many government interventions on the education sector, most indicators in education have registered considerable improvements. Accordingly, significant achievements with regard to pre-primary, primary education, promotion of gender equity, empowerment of women are registered. The government has embarked on efforts to promote pre-primary education with the view to accelerating the modest progress that has been achieved so far. Net enrolment at pre-primary level of 5 to 6 years old children increased from 24.6 percent in 2004 to 33.1 percent in June 2007. Gross Enrolment Ratio and Net Enrolment Ratio of both boys and girls including children with disabilities has at primary schools has also increased from 114.4 percent and 96.1 percent in 2006 to 114.4 percent and 97.3 percent in 2007, respectively. Gross Enrolment Ratio and Net Enrolment Ratio in secondary schools improved from 6.6 and 5.0 in 2000 to 11.7 and 10.1 in 2006, respectively. The government is on track in attaining gender parity with regard to enrolment of girls and boys at the primary school level while retention rate is also recording remarkable achievements.

The pass rate in final Primary School National Examinations (Standard VII) has improved from 22 percent in 2000 to 70.5 percent in 2006 . The projected rate of 60 percent was reached in 2005 when the pass rate was 61.5 percent. This performance is a commendable achievement because it is far beyond the MKUKUTA target of 60 percent. The achievement could also partly be attributable to the percentage of cohort completing standard seven, that has reached 78 percent in 
year 2006 and there are clear indications that the MKUKUTA target of 90 percent will be achieved. This has translated into increased transition rates from primary to secondary education. Transition rate increased from 21.7 percent in 2002 to 36.1 percent in 2005 and 67.5 percent in 2006; the record that has surpassed the MKUKUTA target of 50 percent. The girls increase was from 35.6 to 65.2 percent and boys from 36.6 to 69.8 in 2005 to 2006 respectively. In fact, transition rates indicate that secondary school enrolment is with a near gender parity at entry stage. On the other hand, teacher-pupil ratio has also being recording some improvements thereby contributing to the success attained. It declined from 1:58 in 2005 to 1:52 in 2006 though the trend is mixed in between years.

As a result of the above development, the net enrolment rate in secondary education increased from 5.9 percent in 2002 to 13.4 percent and 20.6 percent in 2006 and 2007 respectively, partly attributed to the increased number of secondary schools constructed. The number of primary and secondary schools increased from 11,624 and 927 in 2000 to 14,700 and 1,755 in 2006 respectively. The number of students registered for form one secondary education increased from 243,359 in 2006 to a staggering 401,011 in 2007, equivalent to an increase of 65 percent. The number of students who joined high school (form five) in public schools increased from 15, 509 to 33, 088 in 2005 and 2007 respectively, representing an increase of 19.1 percent.

The expansion in the enrollments has been matched with increases in supporting facilities. During the years under review, 4,677 class rooms were constructed out of a target of 5,832. Likewise, 1,720 teachers' houses were constructed. The number of pupils' desks made was 62,875 compared to the target of 52,785. Also, 2,492,568 school books of various kinds were bought.

With respect to higher learning institutions, student enrollment have increased from 55,134 to 75,346 for academic year 2005/06 to 2006/07 respectively of which percentage of female was 35 and male 65. There has been improvement in gender balance in accessing high education and the government continues to support initiatives in that direction. Such effort include the establishment of Gender Management Units at various public institution of higher learning (DIT, MIST, and TCA) and the lowering the cut off point for female qualification in accessing government loans. Female enrolment rate and overall enrolment are expected to exhibit an upward trend following the implementation of the various sector policies such as higher education, science and technology, as well as vocational and education training policy. The establishment of the Dodoma University will undoubtedly play a significant role in this regard. 
The government has noted with a concern that despite the progress made in the education sector, there are several areas that call for more attention. These includes the increase in students/teacher ratio, the quality of the service delivery as sector embarked in a crash program of recruiting teachers, as well as the fiscal implications in the medium to longer terms of current expansion in enrolment and transition rates. Also, there are areas where very litter has been achieved. For example, only 0.29 percent of children with disabilities are enrolled in schools in 2007 (the ratio was 0.24 percent in 2006) compared to the MKUKUTA target of 20percent.

\section{Goal 2: Improved survival, health and well-being of all children and women and especially vulnerable groups}

Operational targets to be achieved by year 2010 focuses on reducing infant and child mortality, prevalence of stunting and wasting in under fives, hospital based malaria-related mortality amongst under fives, maternal mortality and HIV prevalence among 15-24 pregnant women. It also seeks to increase coverage of births attended by trained personnel, vaccination of infants, and promotion of knowledge based care among health workers for attending among others, people with disabilities and elderly.

Measures to reduce under-five and maternal mortality rates focus on expanding access and quality to healthcare services with focus on most vulnerable groups. Demographic and health survey data shows that both infant and under-five mortality rates exhibited a substantial decline. Under-five and infant mortality decreased from 191 and 115 per thousand live births in 1990 to 112 and 68 in 2005/06 respectively. The proportion of children vaccinated against measles improved from 78.2 percent in 2000 to 87 percent in 2005 (a performance above MKUKUTA target of 85 percent). Furthermore, the coverage of OPVO (polio vaccine given to newborns either after delivery or within 14 days of delivery) increased from 33 percent in 2001 to over 60 percent in each of the last three years.

However, based on DPT-HB3 which usually is taken as a proxy for overall performance in immunization, coverage for 2006 stood at 87 percent thereby exceeding the MKUKUTA target of 85 percent. Furthermore drug supplies and availability is estimated at 80 percent. However, these indicators vary considerably across regions. According to TDHS 2004/05 significant milestones have been achieved with respect to measures related to malnutrition of under-fives compared to previous surveys. The proportion of under-fives stunted (under height for age) and underweight (weight for age) dropped by 6 to 7 point to 38 percent and 22 percent respectively. 
Surprisingly, maternal mortality increased from 529 per 100,000 live births (1996 DHS) to 578 per 100,000 live births (2004/05 DHS). This has been partly attributable to the impact of the HIV and AIDS pandemic. Nevertheless, in accessing maternal health services, 46.0 percent of births had been attended by skilled health workers. Births attended by clinical officers were 2.2 percent while 37.1 percent were attended by nurse or midwife. Births in health facility were 47 percent of all births. Likewise, deliveries recorded in health facilities increased from 725,000 to more than 900,000 in 2003 and 2004, representing an equivalent increase of 60 percent of the expected deliveries.

HIV prevalence in adults is estimated at 7 per cent of the population in 2004, and that the rate was 7.7 per cent for females and 6.3 per cent for males. The prevalence rate in the 15-24 age groups was 3.0 percent for males and 4 percent for females. This kind of data makes it difficult to measure progress over years. However, based on HIV prevalence among the population of women attending antenatal clinics, it is clear that for all ages there has been a significant decline in the prevalence rates. The prevalence declined from 9.6 percent in 2001/02 to 8.2 percent in 2005/06. Within the age group 15-24 prevalence declined from 7.6 percent in 2001/02 to 6.8 percent in 2005/06. With the introduction of ARVs in more than 200 health facilities in 2006/07, 48 percent of the targeted number of people was receiving treatment against the government set target of 100, 0000 people with advanced HIV infection. It is further anticipated that the national campaign for voluntary HIV screening will reduce the rare of transmission.

Efforts to control tuberculosis's have been recording satisfactory results. Efforts in this direction have centered on maintaining successful completion of the treatment. There has been a steady improvement with success rate standing at 82.6 percent (as of 2005), which compares favorably with the WHO gold standard for treatment success of 85 percent. With the advent of HIV and AIDS pandemic, TB cases recorded a staggering upward trend, though recent past years have witnessed a decline in notified cases.

\section{Goal 3: Access to clean, affordable and safe water, sanitation, decent shelter and a safe and sustainable environment and thereby, reduced vulnerability from environmental risk.}

Operational target for this goals focuses on increasing the proportion of population with access to clean and safe water, increased percentage of households with basic sanitation and percentage of school having adequate sanitation facilities. The targets also seeks to reduce water related environmental pollution and vulnerability due to environmental disasters. 
Clean and safe water is clearly a key attribute to quality life and social wellbeing. The government continued to implement the National Water Sector Development Strategy (NWSDS) and Water Sector Development Program (WSDP) which guide the implementation of various water supply and sanitation service delivery projects and water resource management interventions. As a result, there has been a significant progress in this area over the last two years. Supply of clean and safe water in rural areas has increased from 53.5 percent in 2005/6 to 55.7 percent in 2006/7; a two percent increases as targeted in MKUKUTA. The population with access to clean and safe water in urban areas increased from 74 percent in $2005 / 6$ to 78 percent in 2006/7. About 82 percent of water users have their water line installed with water-meter. The 17 percent access to sewerage service in different Urban Water Authorities was maintained and 25 percent of the wastewater generated daily was collected and disposed through sewerage systems. Expansion, rehabilitation and construction of urban sewerage and drainage systems in different municipals and cities had been started to replace worn-out facilities. Implementation of the Rural Water Supply and Sanitation Projects (RWSSP) has begun in 24 districts. About 429 water wells were drilled nationwide. In order to ensure that future demand for water is met, 850 new areas were identified as potential of ground water (water well drilling). In addition, the government continue with Lake Victoria-Kahama-Shinganga project which is designed to produce 120,000 Cubic Meter/day for over 1million people in Mwanza and Shinyanga regions.

Efforts to address environmental pollution have continued over the period. During the period under review, a total of 493 water resources points were inspected to examine water pollutants and environmental degradation agents. Also 3,058 water samples were examined to see their status in terms of germs and poisonous chemical. Over 90 percent of the sample was free from danger under international standards. The target is to reduce water-related environmental pollution levels to less than 10 percent by 2010 .

A draft policy on Occupation Health and Safety and Health and Occupation bill have been developed, in an effort to reduce vulnerability from environmental risk from work places, Incidence of environmental risk from human habit has been addressed by enhancing land use planning. Actions accomplished include establishment and training of rural Land use planning teams for four districts, and facilitation of eleven pilot villages for Iringa, Mbozi, and Masasi and land use plans for Handeni and Kilindi. Other measures include production of 40 samples of building designs for Mwanza city, Tabora and Mbeya Municipalities, eight interim Land Use Plans of urban settlements to arrest the haphazard urban growth, Letters of Offer and Certificates of Title issued, preparing valuations and granting approval of mortgages and transfer of 
properties. Attention also was paid to properties and residences in unplanned settlements with a view to getting them formalized. Sensitization and awareness on land laws has continued along with dissemination of research findings on low-cost housing and construction of three demonstrative low cost housing.

\section{Goal 4: Adequate social protection and provision of basic needs and services for the vulnerable and needy.}

Tanzania has been addressing social protection in a number of ways and for a long time. It includes government led efforts through expanding the pension system, promoting savings and credits, disaster management and enhancing the policy environment. Other efforts have been undertaken by private actors, ranging from charitable institutions, Civil Society Organizations, corporate institution and Government Multisectoral programs like Tanzania Social Action Fund (TASAF) focusing on the most vulnerable groups. TASAF, a multi-sectoral program provides financing for small-scale public investments targeted at meeting the needs of the poor and vulnerable communities, and at contributing to social capital and development at the local level. It facilitates improvements in the socio-economic infrastructure, enhances capacity and skills among the rural and peri-urban communities and creates a safety-net for the poorest section of the community through cash transfer arrangements that require people to participate in public works. Currently, TASAF is piloting a community-based conditional cash transfer (CB-CCT) in most villages in Tanzania.

At the LGA level, the government continued to support the activities of Local Government Loans Board and as a result the assets and investments of the Board have been increasing. The contribution reserve (MCR) is also growing and loans issued to the Councils for implementation of various activities is increasing. Regarding terminal benefits of employees, The Act No. 9 of 2006 transformed Local Government Provident Funds to a pension fund so that LGA employees could get similar benefits to employees in the central government.

All these interventions have been operating within a limited legal and policy framework. The national Multisectoral Social Protection Framework would rationalize and address existing gaps in order to fast track achievements of MKUKUTA goals and targets. Some of the operational targets for adequate social protection and rights of the extremely vulnerable and needy groups in the MKUKUTA are: 
(i) Reduced proportion of children in child labor country wide from 25percent to less than 10percent by 2010

(ii) Increased number of orphans and most vulnerable children reached with effective social protection measures by 2010

(iii) 20 percent of children and adults with disabilities reached with effective social protection measures by 2010 .

(iv) 40percent of eligible older people reached with effective social protection measures by 2010 .

MKUKUTA clearly states the need for a social protection policy framework that will ensure that the needs of the poor are adequately addressed; including preventing the population from falling into poverty and vulnerability. The National Multi-sectoral Social Protection Framework (NMSPF) therefore builds on national efforts to eradicate poverty. It is a social, economic and political measure aimed at ensuring the increased focus, investment and engagement of the Tanzanian population in addressing causes of poverty so that they can monitor progress and benefit from economic growth. It is an instrument that will guide the coordination, implementation, management, harmonization, funding and sustainability of social protection interventions. The NMSPF prioritizes the needs of the less economically active households/individuals and those who are unable to sufficiently address shocks or risks associated with poverty and vulnerability. These groups include children and young people, women, people with disabilities, the elderly and People Living with HIV and AIDS (PLWHA's).

\section{Goal 5: Effective systems to ensure universal access to quality and affordable public services.}

Operational targets for this goal seeks to ensure that there is increased provision of essential infrastructure, proportion of population reporting to be satisfied with health service delivery, planned and serviced human settlements as well as skilled personnel. It also aims at forging effective partnerships between LGA, CSO and private sector so as spearhead effective delivery of basic social services. Improving the rural roads is among the top priorities of the Government in fighting poverty. There are some notable improvements in this area. Preliminary result from the Household Budget Survey (HBS) 2007 indicates that 86 percent of the communities in rural areas spent 30 or fewer minutes to reach the nearest road passable throughout the year. The same in Dar es Salaam and other urban centers are 99 percent and 98 percent, respectively. 
Various measures are being taken and implemented for ensuring the availability of skilled and motivated staff in the required quantity and skill mix in social service sectors. It includes, a three year recruitments permit (February 2006 - February 2009), and the emergency hiring initiative by the Ministry of Health and Social Welfare. About 3,600 staff have been recruited and deployed to various health facilities all over the country between July 2006 and March 30, 2007. At the same time, the Government has provided financial support to 119 staff pursuing postgraduate and specialized studies inside and outside the country. Upon completion, these staff will be deployed to various health facilities with particular attention to underserved areas in both urban and rural areas.

The HBS 2007 preliminary analysis shows that, communities in Dar es Salaam and other urban areas are closer to health services than their counter parts in rural areas, with 93 percent in Dar es Salaam using 30 minutes or less to reach the nearest dispensary or a health center. Figures for other urban centers and rural areas are 90 percent and 69 percent, respectively. Measures are being taken to improve the access to health services by the rural communities, including construction of dispensaries in all villages. During the FY 2006/07 the Government built 225 dispensaries in rural areas. It has also developed a Primary Health Services Development Program (PHSDP) 2007 - 2017, with first phase beginning 2007-2012. The program focuses on strengthening services at district level.

The Government is implementing various measures in order to ensure that schools in both urban and rural areas have the adequate number of skilled and motivated staff. Recruitment of teachers is being fast tracked by reduction of years in training and by putting in place accelerated training plans.

\subsection{Status and Progress of Sector Review}

During the period under review, a number of processes took place within sectors addressing issues related to MKUKTA Cluster II. The main ones are as follows:

\subsubsection{Environmental sector review}

A number of initiatives were done during the year under review geared towards the implementation of MKUKUTA. The government enacted Environment Management Act (EMA) 
in 2004 and has put in place a program to support implementation of EMA in a bid to enforce compliance. Areas where this law has been used effectively include prohibition of manufacturing, importation, selling, buying, and using bags under 30 microns thickness. This regulation also prohibits the use of plastic sachets for water, juice, and milk packaging, regardless of their thickness. Furthermore, the government prepared Environmental Impact Assessment Regulations and Environmental Audit Regulations. These are being used to ensure compliance in environmental management and protection. Other progress in this area includes preparations of the Environmental Quality Standards Regulations; Fees and Charges Regulations; Ozone Depleting Substances Regulations and Strategic Environmental Assessment Regulations. In order to further consolidate efforts to manage and protect environment, the government is in the initial stages for preparing the Economic Instruments Regulations. These regulations will scale up use of environmental resources for economic activities. In order to keep abreast with environment situation regularly the government will be producing the State of the Environment Report after every two years. The first report is in the final stages.

\subsubsection{Education Sector Review}

The latest education sector review was held in early 2006. The review assessed the overall performance of the sector in the context of MKUKUTA, education or all targets, MDGs and other sectors' policies related to education. The review came up with the following key recommendations which are being addressed by the government: Develop a costed planning process for the full sector with clear and timely budget guidelines and MDAs effective submissions; Develop full sector MTEF/PER process including Public Expenditure and Financial Accountability Review (PEFAR); Increase awareness and capacity building amongst MDAs and LGAs on MKUKUTA and its impact on coherent Cluster oriented planning and budgets; and Development partners to improve on predictability of funding through GBS and SBS.

On the other hand, the Ministry of Higher Education, Science and Technology is responsible for higher and technical education sub-sector which comprises Universities, Colleges and Institutes of Technology. The sub-sector also consists other public institutions that were covered in the survey and mapping of non-University public post-secondary education and training institutions. The survey revealed that the sub-sector has 170 non-University public post-secondary education and training institutions. It should also be noted that the survey covered public institutions only.

\subsubsection{Water Sector Review}


The government has continued to consolidate gains achieved in the water sector during year 2006. One of the major steps included the Water Sector Review, undertaken in September 2006. The review led to revision of the National Water Sector Development Strategy that was adopted by the Government in December 2006. Consequently, the Water Sector Development Program (WSDP) was also developed and adopted by the government. The program pulls together subsector programs for rural water supply and sanitation, urban water supply and sewerage and water resource management into a single development program for the sector. The review also resulted into revision of Water Sector Legislations which were presented to the Parliament in January 2007.

\subsubsection{Health Sector Review}

Reforms in this sector are on the $8^{\text {th }}$ year of implementation and currently the government in collaboration with DPs is conducting an external evaluation spearheaded by the Ministry of Finance. Several new developments took place in the health sector. The most notable development is the development of a primary health sector program (MMAM 2007-2017) which is a 10 year program. A road map to implement Maternal and Child Health Program in line with MDG goals 4 and 5 is in place. The HIV/AIDS strategy with a rolling over plan for ARVs treatment, sanitation and hygiene strategy, along with a strategy for non-communicable disease control have been developed. Other developments include:

- Council Health Management Teams and Health Service Boards were established in order to enhance ownership and accountability to the communities.

- The government supported the urban areas in the introduction of a repayment scheme, namely Tiba kwa Kadi (TIKA) to carter for the informal sector.

- Integrated logistic system, aimed at tracking the use of medicines and supplies in order to reduce wastage, has been developed and tested in Dodoma and Iringa.

- Pretest of Kiwahili IMCI modules after incorporation of HIV as conducted for 32 health workers in selected districts.

- The Prevention of Mother to Child Transmission of HIV (PMCT) services has been rolled out from pilot areas (mainly referral hospitals) to nine regional hospitals.

\subsection{Challenges}


In line with the various developments that are taking place in improving quality of life and social wellbeing, a number of challenges remain imminent in key areas. Some of the specific challenges include:

(i) Safeguarding of education standards and quality at all levels remains a critical challenge when considering the relatively large increase in enrolment rates. This should be in tandem with the expansion of education facilities such as more classrooms to address overcrowding, teaching materials, teacher's houses, toilet facilities and the appropriate number of qualified teacher to pupil/student ratio.

(ii) There are still gender disparities in enrolment at upper secondary and tertiary levels of education. The main challenges here are basically on the retention and performance of girls which could be directly attributed to inability to meet costs, labor market demands, and early pregnancies and marriages. These factors contribute significantly to school drop out among girls in both rural and urban areas.

(iii) Also there are challenges of sustaining achievements attained in DPT-HB3 immunization coverage and scaling up to all regions, reductions in new cases of TB, and making counseling and testing for HIV and AIDS as a routine.

(iv) There is a need for rehabilitation, expansion and construction of water and sanitation networks and encourage the proper use of latrines and waste disposal as well as upgrading the unplanned settlements.

(v) The challenge is also on the raising magnitude of special needy groups, compounded by transmitted diseases and especially rising destitution brought about by scourges of HIV/AIDS on families and structure of dependency featuring families headed by children and aged ones.

(vi) There are inadequate - qualified staffs that need skills upgrading in both education and health sectors as well as in the LGAs. For example, human resource gap in the health sector is estimated at 67 percent. This gap is accompanied by poor motivation to staffs particularly those working in remote rural and underprivileged areas.

\subsection{Lessons}

Some of the quick lessons that could be drawn from the achievements and challenges discussed includes among others: 
(i) The participation of local communities by providing planning, material and financial contribution to their development projects is paramount in attaining most of the goals envisaged in this cluster;

(i) Lack of adequate facilities, including housing facilities, in most rural communities and underprivileged areas discourage most workers in social sectors from working in the areas;

(ii) Inadequate access to sufficient basic social services such as water and alternative sources of fuel undermines education initiatives at household level; as the two consumes a lot of time that could be used in other productive activities;

(iii) Increasing the percentage of teachers with relevant qualifications is in itself a necessary but not a sufficient condition towards quality improvement.

(iv) Increased immunization and vaccination, as well as nutritional improvements played a greater role in reducing malnutrition, infant and child mortality, as well as a drop in stunting and wasting.

\subsection{The way forward}

The challenges encountered in attaining desired objectives in cluster II call for concerted efforts by all stakeholders to work out quick measures that will make the attainment of MKUKUTA goals a reality. To address these challenges:

The Government will continue to enhance the quality and standard of education through programs that focus to increase the number of qualified and professional teachers, school facilities as well as other social amenities that improve school's environments. Efforts will also be directed to gender disparities where by programs that will provide priories for girls across all education level will be considered.

Capacity building for LGAs staffs will continue to be enhanced as a way of strengthening management of public resources. Effort will also be directed to explore the possibility of promoting distance learning for both workers in the social sector will be enhanced. These will improve their capacity and competency especially based in rural and underprivileged communities.

Concerted effort from all stakeholders will be directed to reverse the negative trend in maternal mortality as well as scaling up implementation of the National HIV/AIDS Multisectoral 
Framework including, and scaling up of ARVs coverage. Efforts will also dwells on developing guidelines and mechanisms for mainstreaming OVC issues in MDAs including building capacity of state and non state actors on issues of disabilities and elderly.

With regards to social services provision, focus will continue to be directed to enhance both quantity and quality of services with the adoption of the public-private partnership. Efforts to institutionalize the social protection arrangements will also be adhered while considering the vulnerable groups. Environmental campaigns will also be scaled up to raise awareness on environmental conservation and protection.

In summary, most indicators of social wellbeing and quality of life have recorded remarkable improvement during the period under review. In some aspects, the government has out performed the MKUKUTA targets. Such outturn in the real quality of life and social wellbeing is an evidence of, among others, government's commitments to allocate more resources to finance MKUKUTA activities following considerable increases in domestic revenue collections and supports from development partners. The underlying factors for the macroeconomic environment and the progress in the provision of social services it has supported is the improvement are the legal and institutional frameworks which foster both good governance and accountability. While issues of improvement in MKUKUTA financing are discussed in Chapter $\mathrm{V}$, the next chapter dwells on the progress so far made in enhancing good governance and accountability. 


\section{CHAPTER FOUR: GOVERNANCE AND ACCOUNTABILITY}

\subsection{Overview}

To ensure that growth is broad-based and that improvement of quality life and social well being takes place, good governance has to prevail. MKUKUTA underscores this fact and emphasizes putting in place economic structures and processes to ensure transparent and accountable use of public resources (financial, information and natural resources), management systems, personal security, tolerance and inclusion, and participation in decision making. This chapter presents implementation progress on Governance and Accountability highlighting overall performance of each goal based on a set of outcome and process indicators. The chapter also reflects on challenges, lessons learned in the due course of implementing cluster strategies and the way forward.

The cluster has seven goals, namely: Ensure that structure and systems of governance as well as the rule of law are democratic, participatory, representative, accountable and inclusive; Equitable allocation of public resources with corruption is effectively addressed; Effective public service framework is in place to provide foundation for service delivery that support poverty reduction; Rights of the poor and vulnerable groups are protected and promoted in the justice system; Reduction of political and social exclusion and intolerance; Improvement of personal and material securities, reduced crime, eliminate sexual abuse and domestic violence; and lastly to Promote and enhance national cultural identities.

\subsection{Performance and progress}

Goal 1: Structures and systems of governance as well as the rule of law are democratic, participatory, representative, accountable and inclusive

\section{Performance:}

The main operational target for this goal is to ensure that there is a wide representation in all levels of government structures with the focus on the poor and vulnerable groups, while ensuring that accountability and good governance becomes a culture in all MDAs and LGAs.

The intention to narrow the gender gap in both political and government decision making has been spelt out clearly in the CCM Party Manifesto. Thus, it has also been a government policy. 
As a result, the number and the proportion of female employees in public sector is increasing. Proportion of women in decision making position at Central government was 26.8 percent in 2005 and increased to 29.1 percent in 2006 closer to MKUKUTA target of 30 percent. In 2006, the proportions of women in decision making position in Local government and regional secretariat level are 38.36 percent and 25.44 percent respectively. Female permanent secretaries are currently 27.8 percent while that of commissioners and directors in the government is 15 percent and 29 percent respectively. Proportion of Female Assistant Directors is 28.2 percent of the total number of Assistant Directors in the Civil Service. District Administrative secretaries make 11.7 percent. At LGA level female decision makers make a significant proportion. Female Executive Directors are 26.4 percent. At the political level, female ministers comprise of 19 percent of the ministers.

With regards to the number of women representatives in Parliament, there has been a remarkable achievement whereby the current proportion stands at 30.4 percent which marks as the highest rate compared to any East and Central African country.

Other areas relating to this goal have also shown significant progress. These areas included community governance initiatives and community meetings. According to the 2007 HBS community characteristics, over 50 percent of the communities have indicated to have governance initiatives. Over 95 percent of annual community meetings take place in the communities.

The government has been implementing Legal Sector Reform Program for sometimes now. The reform has brought significant improvement in many aspects. With respect to the rule of law, the government has decreed and put a clause that provides for ruling of cases within 90 days after completion of hearing. Furthermore, 52 percent of all prisons were visited and complains of prisoners were dealt; 27 percent of referral cases were held. Significant progress was also made to speed up hearing of cases related to commercial, land and human rights. In 2005/06 ruling of 91 percent of all commercial cases was made. Ruling of land and human right cases were 32 percent and 70 percent respectively. Significant achievements were also noted in terms of fast tracking the registration and documentations of birth, death and marriages. In 2007 about 46,320 marriages, 829,384 births and 118,538 deaths were registered. 


\section{Goal 2: Equitable allocation of public resources with corruption effectively addressed}

There are two operational targets that are being addressed under this goal. These are (i) allocation, accessibility and use of public resources in an equitable, accountable and transparent manner and (ii) instituting effective regulations and mechanisms regarding petty and grand corruption.

Efforts have been put in place to ensure equitable allocation of public resources and addressing the corruption vice, the government has instituted measures to improve domestic revenue collection. These include broadening tax base through registration of new tax payers, and restructuring of the tax system. These measures have shown a positive trend. For instance, domestic revenue during the FY2006/07 reached 111. 3 percent (by March, 2007) of the annual domestic revenue budget estimate. Other measures include training and awareness-raising among government staff on corruption and strengthening of complaints mechanism in the public services delivery. The government has also strengthened the National Audit Office (NAO), a measure that has resulted into more audited MDA's, Regions, Local Government Authorities and Embassies on time. The government has also strengthened compliance with Public Procurement Act and procedures, as a result more MDA's and LGA's complied with the Act. The notable achievements in the councils has been a full (100 percent ) compliance by LGAs towards posting information regarding budgets, revenue and actual expenditure on the public notice boards for public use.

In terms of allocation of financial resources, all LGAs have been provided resources in more transparent and equitable manner through a formula based grant allocation system. A significant amount of funds that formerly used to be transferred through Ministerial Votes are now sent directly to the LGAs. A total of Tshs 286 billion from PMO RALG and five Sectoral Ministries were transferred to LGAs in 2006/07. Establishment of ministerial task force is underway to speed up the process so that more resources are directly allocated to LGAs. These efforts would expedite the process of amending the sector specific laws in conformity with the government policy of Decentralization by Devolution (D by D).

In strengthening supply of quality LGAs staff, the government continued to support the Hombolo Local Government Training Institute. Preparation for starting Certificate and Diploma courses are at an advance stage. Nevertheless, the institute continued with short courses, where by 240 Village Executive Officers, 102 Mtaa Executive Officers, 2,663 Village and Mtaa Chairpersons, and 300 Ward Executive Officers, and 87 Councilors were trained during the year under review. 
The government continued to strengthen financial management at LGAs. A total of 85 out of 133 councils have been connected to the Integrated Financial Management System (IFMS) network. The Government has also employed 207 accountants and 64 auditors in various councils to improve financial performances. There is significant improvement in financial controls, whereby 53 councils received clean certificate, 67 conditional certificate, and only four received adverse opinion.

A significant achievement has also been made in corruption control. The number of cases reported by PCCB has increased significantly from 1,244 in 2000 to 3,121 in 2005. The Achievement is attributed by number of interventions including strengthening and restructuring of PCCB and approval of the Public Procurement Act of 2004. In 2007, 15 cases out of 19 qualified for court hearing. Disciplinary actions related to corruption have also been taken on public officers. Other interventions include seminars on ethical matters to law enforcers as well as increased awareness through radio and TV programs.

\section{Goal 3: Effective public service framework in place to provide foundation for service delivery improvements and poverty reduction}

Effective Public service delivery is vital for poverty reduction. Its improvement overtime is therefore, an important component in ensuring good governance and accountability. Realization of this goal entails: (i) Placing administrative system of public institutions and its transparent management in the interest of people that are served (ii) Institutionalization and implementation of D by D to enhance public ownership of development and poverty reduction process.

Satisfaction with the Government services: Improvement in quality, accessibility and affordability of services are gauged through clients' perception. But the clients are likely to be served better when civil servants are motivated. Recognizing this, efforts have been directed to increase the pay levels in the civil services through the pay reform component of the Public Service Reform Program. The improvement is also going to have positive bearing on the war against poverty.

The government continues to increase the public satisfaction from its services by increasing access and reducing time costs through improvement in basic facilities (e.g. roads) and service delivery centers (e.g. schools, dispensary, etc.). The 2007 HBS community characteristics indicates that 69 percent, 90 percent, 93 percent of rural areas, other urban centers, and Dar es Salaam respectively, are reporting to use 30 or less minutes to reach the nearest health center or 
dispensary. Likewise, about 61 percent, 91 percent, and 98 percent of rural communities, other urban centers, and Dar es Salaam respectively, spend 30 minutes or less to access the nearest government secondary school. All communities in other urban areas spend 30 minutes or less to access the nearest primary schools. In rural areas, 94 percent of the communities need up to 30 minutes to access pre-primary schools compared to 99 percent of the communities in both Dar as Salaam and other urban centers.

Decentralization by Devolution ( $D$ by $D$ ): The government is implementing decentralization policy through devolution. A significant improvement has been registered with regard to D by D. The application of formula based allocation of development funds under Local Government Capital Development Grant (LGCDG) system has resulted into an increase of resources flowing to LGAs up to 19.7 percent (2007/08) compared to 16.1 percent during 2006/07 financial year. Additionally, efforts were made in the area of capacity building for both councilors and LGAs staff for the purpose of enabling the councils to make correct decisions and enhance technical capacity of the staff.

\section{Goal 4: Rights of the poor and vulnerable groups are protected and promoted in the justice system}

An effective judicial system is critical in attaining MKUKUTA goals on governance and the rule of law. The government recognizes the need for gauging overtime the efficiency of the judicial system particularly in relation to vulnerable groups. In order to realize the goal on protection and promotion of the rights of the vulnerable groups, judicial system focuses on improvement of outstanding court cases backlog, case screening and prosecution process.

Outstanding court cases back log: Much effort has been put in place in-tandem with the Legal Sector Reform Program (LSRP) whereby the assessment indicates that the percentage of outstanding court cases have dropped from 58 percent in 2005 to 46.7 percent in 2007. These achievements have been contributed by the improvement of capacity of judicial system whereby a total number of 12 sessions of the Court of Appeal were conducted and a total of 978 appeals were heard. Similarly, 98 sessions of the High Court were conducted in all 13 zones and 1,111 cases were disposed by the Director of Public Prosecution. These changes imply that implementation of MKUKUTA in this goal is on track and the initiatives employed are effective. The trend indicates that the target of reducing percentage of outstanding court cases to 40 percent by 2010 is likely be achieved. 
As regard to speeding up filed cases, various initiatives have been considered, these includes appointment of 23 Judges, two for Court of Appeal and 21 for the High Court. A total of 77 Resident Magistrates and 46 Primary Court Magistrates have been recruited. The government employed 12 State Attorneys and seven Law Secretaries. These were allocated to zonal offices of the Attorney General's Chambers.

Case Screening and Prosecution Process: A technical study on the transformation of the prosecution system in the country has been finalized. Recommendations on the legal and the structure of the national prosecution services are at the securitization stage. Also, a needs assessment for Legal Sector Reform Program (LSRP) Phase I civilianization of prosecution services has been accomplished in six regions. Moreover, an authorization of recruiting a total of 211 attorneys and supporting staff for LSRP Phase I and their remuneration packages has been granted.

\section{Goal 5: Reduction of Political and Social Exclusion and Intolerance}

This goal focuses on developing and strengthening both political and social systems that provide more participation of citizens, particularly the poor and the most vulnerable ones.

The government continues to abide to various international human rights conversions which it has ratified. Consequently, a number of initiatives have been put in place such as enhancement of the capacity of the Commission for Human Rights, creating awareness of stakeholders regarding human rights, building capacity of NGOs on monitoring and reporting human rights abuse, and promotion of collaboration to regional and international human rights agencies.

In year 2006/07 the Commission for Human Rights and Good Governance received 226 complaints on human rights violations from remandees whereby 39 complaints were advised and 187 were resolved. A total of 4,523 new complaints on human rights violation were received and out of them 3,149 complaints were resolved. This is about 70 percent of the total backlog. While the increase in reported and filed cases is a positive indication of awareness among the people in understanding their rights, the quick out turn of received and resolved cases shows improvement of capacity of the Commission.

In order to ensure that rights of the people are respected and any violation or abuse are reported to the Commission especially for the remote areas, the Commission has opened two Regional 
Offices located in Lindi and Mwanza Regions. This will assist the commission to fast track service deliveries to the lower level and especially for the rural marginalized women.

The government has continued to strengthen the inspectorate capacity of the Commission for Human Rights. In 2006/07 the commission inspected 35 prisons and 53 police stations in 33 districts of Tanzania Mainland with the view to assessing and seeing whether the environment comply with human rights and good governance. The inspection reports regarding the general environment of both prisons and police stations and the proposed recommendations have been widely shared and disseminated.

Campaigns for human rights and good governance awareness and the importance of rule of law were conducted covering 36 districts in Mainland Tanzania. In the course of fast tracking human rights awareness campaigns, the Commission for Human Rights has opted to adopt a Public Private Partnership Approach and already 18 non state actors have been assessed to see their capacity to collaborate with the Commission for Human Rights and Good Governance. Related to this is the progress that has been made in resolving the political tension in Zanzibar between the followers of the two major political parties. REDET (University of Dar es Salaam) initiated a training program aimed at fostering tolerance in Zanzibar. The potential of scaling up this initiative to other areas needs to be explored.

Goal 6: Improved personal and material securities, reduced crime, eliminate sexual abuse and domestic violence.

The operational target here is to ensure institutions and agents of government such as the police, courts and prisons observe human rights and ensure justice and security of all citizens. A number of strategies have been implemented and aligned to the review of the LSRP aiming at attaining the target.

Progress under this goal indicates satisfactory results; however, the number of inmates in prisons is still higher compare to the capacity. Number of inmates was marginally reduced from 44,565 (June 2006) to 39,782 (June 2007). In the course of ensuring the number of prisoners is reduced, the government through the Prison Act, No. 34 of 1967 managed to allow 931 prisoners to serve their sentences out of the prison and beneficiaries obligated to serve for community works such as cleaning and maintaining public roads, environmental caring in hospitals and offices. On the 
other hand carrying capacity of prisons increased from 22,699 to 27,653 inmates in 2005/06 and 2006/07 respectively. This is attributed to rehabilitation and expansion of various prisons.

Satisfactory progress has been made in the reported number of cases of crimes whereby there is a significant increase of file cases in both levels of judiciary. For example, from year 2005 to 2006 at the District Court file cases increased by more than 100 percent. At the High Court the increase was about 32 percent and in the Court of Appeal there was a minor increase of less than 1 percent. In general, this significant development implies that people have started to understand their rights as well as improved accessibility to legal services, which is mainly attributed to the reforms undertaken by the government through LSRP.

The Law Reform Commission conducted a research on customary laws in Tanzania. The findings of the report have initiated amendments on customary laws that are biased and suppress women in Tanzania. This will assist to reduce to a greater extent the rate of sexual abuse and other related social convictions.

There are notable achievements in terms of reduction in the number of reported of incidences of crime at Police Stations. This has declined for about 17 percent in year 2006 when compared to year 2005, mainly as a result of the ongoing reforms of the Police Force inline with the review of the LSRP. The decline is also attributed by cordial collaboration with other regional and international agencies such as Interpol.

Capacity building on Human Rights and Good Governance was conducted for 967 Police Officers as of May 2007, while other 13 officers were sent abroad for particular professional skill enhancement. In a bid to improve application of rule of law and good governance 86 Police Officers managed to attend short courses that are conducted on a bilateral country's agreements.

Advancement and promotion of the application of ICT in the police force has taken place whereby LAN/WAN connectivity for police stations was done in various regions particularly Mbeya, Mwanza, Dodoma, Arusha, Zanzibar, Police Headquarters Dar es Salaam, and Dar es Salaam Special Zone, as well as the three police training colleges of Dar es Salaam, Zanzibar and Moshi. Furthermore, 51 and 54 Primary Courts were rehabilitated in 2005/06 and 2006/07, respectively. Also 15 and 13 new Primary Courts were constructed in the respective years under review. This measure will greatly improve dispensation of justice in the coming years. 
There are also significant progresses in the areas of specialized courts. The Commercial Court disposed 140 commercial disputes out of 153 in 2006. In 2005 it disposed 91 disputes out of 115. The Land Court disposed 476 out of 787 land disputes in 2005/06 and 612 out of 1915 in 2006/07. However, these specialized courts are still understaffed.

\section{Goal 7: National cultural identities enhanced and promoted}

The Government has continued to promote culture and sport in order to have a society which has cultural life and national language as major national identity. Among major progress include training of 2840 individuals in music, fine arts, theatre arts traditional and modern dance, and acrobatic. Also, a study to identify artistic resources was conducted in Ruvuma, Mtwara, and Kilimanjaro. Furthermore, the Government has acquired land for construction of National House Culture Complex. In order to increase awareness on intellectual property rights, 330 artists were trained on issues pertaining to copyrights. Other interventions were directed to promote cultural festivals (e.g. Zeze Award), increased support to Bagamoyo College of Arts, as well as inspecting films and video in order to protect the national culture.

During the period under review, the government continued to promote Kiswahili as one of the major national identity in various ways. Over 500 certificates and 50 documents were translated into Kiswahili and 156 TV and radio programs on Kiswahili language were broadcasted. Also, 180 mistakes in Kiswahili words were identified and corrected. The period under review also witnessed increased use of Kiswahili at the international level, e.g. in African Union meetings.

In the area of sports and games, 124 and 241 sport associations, clubs, and sport centers were registered in 2005 and 2006, respectively. The Government continued with phase one of the construction of the national sport complex, rehabilitation of national football stadium, and employed sports trainers of international standards. Some outcomes have already been noted in terms of improved performance of the national teams in international tournaments, particularly the national football team. In order to promote professionalism in sports and games, Malya Sport College has been improved where by 36 students are now enrolled for courses in football, netball, volleyball, basketball, and athletics. Furthermore, in order to promote traditional games, the government has published a book titled: Mchezo wa Bao.

\subsection{Status and progress of reforms}


In order to hasten progress in governance and accountability, the Government has put in palace various reforms. These reforms have had a profound impact on achievements made in the area of good governance and accountability. These are the Legal Sector Reform Program (LSRP), Public Service Reform Program (PSRP), Local Government Reform Program (LGRP), and the National Anti-Corruption Strategy and Action Plan (NACSAP).

\subsubsection{The Legal Sector Reform Program (LSRP)}

The most outstanding achievement for the period has been the enactment of Legislation to establish the Law School of Tanzania in 2007. The Law School of Tanzania (LST) will improve service delivery in the legal profession. Also, through the reform program, the government has developed and approved a legal framework and structure of the National Prosecution Service in order to speed up the prosecution procedures. The LSRP also led to Modernization and strengthening of the investigation system for the Police force and Improvement of performance of the judiciary as well as improved access to justice. The government simplified rules, procedures and guidelines for various stages of investigation, mediation and reconciliation. The Legal Sector Policy final document is in place and is currently disseminated and shared with stakeholders for critical inputs. Efforts have been made to increase public awareness for the understanding of the national constitution, and 2 Laws with other 3 subsidiary legislations by translating them from Swahili to English.

\subsubsection{Public Service Reform Program (PSRP)}

Achievements have been made in enhancing performance of public service delivery. Installation of a number of key systems and processes in various MDAs has been done in line with the harmonization of the national planning and budgeting processes. Rolling out of subject file management systems to MDAs and the promotion of more decentralized decision making through reengineering human resource processes are ongoing. Implementation of PSRP has resulted into launching of more Executive Agencies and improvement of pay levels for the public servants.

The government has designed the PSRP Phase II that is expected to be effective by December 2007. The PSRP Phase II will adopt a demand driven implementation approach, creating more enabling environment for the MDAs to manage reforms in their institutions. PSRP II will focus more on strengthening demand side of accountability through involving more citizens, stakeholders, and CSOs in MDAs service delivery interventions including policy dialogue. 


\subsubsection{Local Government Reform Program (LGRP)}

The government is currently implementing the third Medium Term Plan under the LGRP. The core reforms implemented are related to political administration, fiscal decentralizations, good governance and the central-local relations and restructuring. However, the notable achievement has been in the areas of fiscal decentralization especially formula based allocation of development funds under the LGCDG system. Decentralization by Devolution has started in five ministries. Capacity building activities to empower councilors and LGAs staff to make correct decisions are being conducted. Organization restructuring of LGA's to improve service deliveries are being made. The sense of ownership among the communities has been increasing through their involvement directly or through representation in day to day business of LGAs.

\subsubsection{National Anti-Corruption Strategy and Action Plan (NACSAP)}

The government formulated the National Anti Corruption Strategy and Action Plan II (NACSAP II) basing on the critical consideration of the successes, problems and challenges of the NACSAP I. As a result a new and more enhanced Anti-Corruption legislation has been enacted (June 2007). The legislation will improve the effectiveness of Prevention and Combating of Corruption Bureau (PCCB). Effort is also directed to establish National Anti-Corruption Forum in order to increase the participation of a wide range of stakeholders.

\subsubsection{Public Financial Management Reform Program:}

Significant progress has been made under several components of the PFMRP. Particularly noteworthy are the strengthening of macroeconomic programming and improvement of fiscal marksmanship; the stronger coordination of external aid; the greater timeliness of external audit reports; and the elaboration of the integrated financial management information system (IFMS) and its progressive rollout throughout central government and parts of local government. Substantial progress has been made in budget preparation as well, through the concurrent introduction of the MTEF and the ongoing Public Expenditure Review process. However, as noted earlier, the most important and longest-gestating challenge in Public Financial Management is to strengthen budget preparation and operational management in the MDAs and local 
government, which is essential for durable improvements in the efficiency and effectiveness of public services.

\subsection{Challenges}

Generally, throughout the implementation period there are a number of challenges that have been observed which require further attention. One of the challenges in relation to information posting in the notice board is inadequate analysis cum consumption of the same information by the community at the grass root level. Furthermore, most of the notice boards are inaccessible as they are found in the district headquarters and not in the village centers.

It is also noted that there is inadequate infrastructures (i.e. offices, office equipments, housing, communication equipments) for law enforcers (i.e. Police, Prison, Courtroom, and legal systems); inadequate remunerations that are compelling them to take bribe; Inadequate human resource and capacity building to implement interventions. These challenges have, in many cases, resulted in laxity of the court systems and police investigation. Also critical is the overcrowding in prisons due to inadequate expansions in these facilities.

In the aspect of fiscal decentralization, the key challenge is the inadequate capacity to cope up with increased flow of funds to LGA. This implies that there is urgent need to match the devolution process with capacity enhancing programs. There is also a need to increase the understanding among the central and local government officials on what decentralization by devolution concept entails.

Auditing of public resources also faced shortage of resources to conduct audits on all the accounts. As regards to the human resource allocation, remote areas have been on the disadvantages as majority declines to be posted in those areas. Other challenges related to corruption include poor regulation in natural resource management, inadequate participation of communities in natural resources management.

Accomplishing effective modality of involving non-state actors in the implementation of NACSAP II stands also to be among key challenges. On new procurement act, the challenge has been on the performance of tender boards.

Although some progress has been made in the area of legal reforms, there are still challenges in relation to improvement of the judiciary system. Rationalization and harmonization of the levels of pay for staff working under legal sector reform program is crucial for smooth take-off of the Program. The need to fast track case flow management, increase the independence of judiciary, 
enhanced information to the ordinary citizen on the role and function of the judiciary systems have been noted to be important aspects of legal reforms.

Skills development and enhancement in Human Rights understanding and frequent monitoring, modern technology for dissemination and sensitization as well as equipment has also stands to be a key challenge in meeting the stated objectives. Areas where these are critical include prisons and refugees camps. The focus of trying to adopt a kind of public-private partnership in delivering human rights pose a challenge of identifying credible NGOs in districts.

Existence of poor technology for dealing with the current sophisticated crimes such as transnational organized crimes (terrorism, money laundering, drug trafficking, illegal immigrants, etc) has been a challenge on the side of the police forces. In the aspect of prisons capacity, yet the average number of inmates per facility as percentage of authorized capacity is more than the recommended rate. Also there is a gap of availability of national data on sexual abuse and domestic violence.

\subsection{Lessons}

There are a number of lessons that have been learnt in the process of trying to achieve the targeted goals and objectives. Notably is that, there is a very low level of awareness at the grass root level particularly with respect to the use of public information provided by LGAs. There is a need to disaggregate the available information and perhaps to conduct a study to establish baseline information with respect to total number of people who own CCROs at household level and by gender. There is also a need to build capacity and improve the working conditions of law enforcers. It is evidently that improvement of interventions in this cluster will act as catalyst to achievements of outcomes in growth and reduction of poverty and social wellbeing outcomes.

In order to effectively reduce corruption, more awareness is required to change mindset of public office holders. The auditing activities of the public institutions need to be strengthened to reduce divergence of resources in public institutions. There is also a need to strengthen capacity and pay attention to accounting units of public offices. There is a need to harmonize the process of decentralization by devolution in the constitution in order to ensure consistency, continuity and efficient implementation of the D by D. In a wide scale, it has also been noted that formal coordination among various reform programs (LSRP, PSRP, LGRP, etc) is lacking yet essential for achieving their respective goals. Also related is the need to remove contradictions in some sector laws. 


\subsection{Way forward}

The government in collaboration with stakeholders will need to scale up awareness raising activities to the community at large with respect to the role and usefulness of public information and conduct more training on ethics and integrity in professionalism so as to enhance good governance and accountability. There is a need to conduct a baseline survey for key performance indicators for future monitoring and evaluation purposes. Efforts should be directed to improve working infrastructures and conditions. As regards to the posting of information in the notice board, modality to involve non state actors should be investigated and institutionalized for them to participate fully in improving the public accountability.

Other areas for consideration include; capacity building interventions recruitment of more staff, reduction of case backlog, improvement of communication infrastructure and putting comprehensive system for good governance, accountability and representation. More involvement of community in managing the natural resources is needed and capacity building of the LGAs staff to manage resources and services deliveries is required.

Equally important areas in relation to human rights include the expansion of prison facilities and installation of offenders' information management systems. The government also needs to scale up control and monitoring of its borders. There is also a need to scale up the Community Service Program and Fire and Rescue Services in all regions.

The Government has made significant strides in addressing issues of economic growth, reduction of income poverty, improvement in quality of life and social wellbeing, good governance and accountability. The mileages covered so far entailed significant commitment in terms of financial resources, review of the legal and regulatory framework as well as introduction of new ones. The next chapter expounds on issues of MKUKUTA financing, highlighting major aspects of resource mobilization, budget execution and reporting as well as other policies related to Government budget. 


\section{CHAPTER FIVE: MKUKUTA FINANCING}

This chapter provides an overview of overall fiscal performance and strategic resource allocation in relation to MKUKUTA. Among other areas, it provides information on progress made so far in resource mobilization, budget preparation, execution, reporting and transparency.

\subsection{Resource mobilization, Allocation and Budget Consistency}

Implementation of MKUKUTA lies not only on the public sector but also other non state actors. Given the complex nature in capturing information on contributions of other players in MKUKUTA implementation, this report reflects on the government financing as a major contributor. As opposed to the earlier financing framework under the first PRS, which focused on sector based resource allocation, MKUKUTA acknowledges the fact that all MDAs and sectors contribute to poverty reduction efforts. This direction, which is widely shared by many stakeholders, triggered complementary initiatives such as the Joint Assistance Strategy for Tanzania (JAST) aiming at facilitating the intended MKUKUTA objectives in a cost effective manner. There has been substantial progress in harmonizing donor assistance through the (JAST) which has resulted in reduction of transaction costs. The General Budget Support (GBS) and Public Expenditure Reviews are some of the instruments which are utilized for consolidating government as well as development partners' efforts towards supporting poverty reducing interventions in the country.

Notable achievements include an upsurge in development partners' budget support, from Tshs 1,030 billion in the first two years of PRS to Tshs 3,090 billion in the first two years of MKUKUTA implementation. Domestic revenue collection also has risen significantly, from Tshs 1,973 billion in the first two years of PRS to Tshs 4,897 billion in the first two years of MKUKUTA implementation. These increases are partly on account of major reforms undertaken in the main collecting agents for domestic revenues, and improved public finance management which has enhanced development partner' confidence in Tanzania.

The Government is making progress in the budget management (formulation and implementation) process. The link between MKUKUTA priorities and budgetary resources allocation continues to be improved and strengthened annually. Planned expenditures are programmed in line with the MKUKUTA cluster's priorities, through the Strategic Budget 
Allocation System (SBAS) at the central Government level and the sister Planning and Reporting (planned) software for local Governments. The SBAS was rolled out to the Regional Secretariats in the preparation of the 2006/07 budget. Together, the systems facilitate MKUKUTA - based budgetary resources allocation for the entire government budget. The initiative has also been assisted by the ongoing MKUKUTA and MDGs costing exercise whose interim results together with the cluster based for PER consultation; have been used to prioritize interventions for resource allocation. Completion of the MKUKUTA costing exercise will further strengthen the Government's effort to prioritize and link the resource allocation with MKUKUTA. Eight sectors that have completed MKUKUTA costing are health, education, water, roads, agriculture, land, labour and energy.

Despite of these remarkable achievements in the budget management process, there are several challenges remaining;

- to concretize and integrate the non state actors' contribution in poverty reducing efforts. The effectiveness of the use of public resources would benefit from integration of private sector and civil society interventions in the planning process. Various players, including the private sector, non-state actors and development partners will be encouraged to share information related to poverty reducing efforts in the course of developing the next MKUKUTA implementation report, as the first step towards full integration of such inputs in the plans of different sectors.

- Resources generated for MKUKUTA implementation are not sufficient to cover adequately earmarked interventions. Resources mobilization is therefore at centre stage of poverty reduction strategies. The Government will continue to seek ways to increase domestic tax and non - tax revenues, while encouraging development partners to increase their contribution in line with commitments at international and local (Tanzania) level. The government will need to speed up considering possibility of employing PPP s arrangement in some projects and ensure that new revenue sources are explored.

- Foreign resources predictability is still an issue to be addressed

- Inadequate resources 
- Macroeconomic constants outing form the relevance of mode of financing, and the structure of the budget

- The need for clear guidance on the resource constraints, which would reduce (if not eliminate) unrealistic requests by MDAs.

- The need for guidance on the level of details on initial budget submission by MDAs to avoid the highly detailed (activity) submissions which normally lack a strategic framework, and

- The need to improve the connectivity (linkage) between budget and program documents, as well as coordination and authority between budget and program officers within MDAs.

\subsection{MKUKUTA Structure and the Budget:}

The broad based MKUKUTA recognizes that all sectors and MDAs have a contribution to make to poverty reduction agenda. With growth and poverty reduction as the fulcrum around which all Government planning rotates, the entire Government budget may be said to be for MKUKUTA implementation. For analytic and planning purposes, however, the expenditure directly related, to specific MKUKUTA cluster strategic are classified as MKUKUTA expenditures.

Within the SBAS framework, the approved budget to implement MKUKUTA in 2006/07 was 48 percent of the total budget allocations. The remaining 52 percent was for projects and programs that does not have direct link to MKUKUTA targets and outcomes. This category includes Wages and Salaries, LGAs and CFS which account for 18percent, 12percent and 10percent of total budget in 2006/07 respectively. Out of the budget for MKUKUTA interventions, 46percent was budgeted for the implementation of policies, programs and projects under Cluster 1, 36 percent for Cluster 2 and 18 percent for Cluster 3. This is in line with the objective of scaling up growth and increasing the income for poverty reduction of the poor majority. The government is being working on establishing the actual expenditure for 2006/07 derived from the IFMS based on MKUKUTA clusters. Preliminary analysis of the actual releases for FY 2006/07 shows that disbursement of funds for the implementation of various MKUKUTA activities was satisfactory, albeit with some deviations from initial budget allocations. These deviations were attributed mainly to the government decision to reallocate funds from less to more priority areas in response 
to power crisis experienced in the first half of 2006/07, food shortages, oil prices and increasing domestic interest payments.

It should be noted that social spending constitutes long term investment in human capital, the quantity and quality of which are critical for attaining growth, which is one of the key objective of MKUKUTA. However, there is a big challenge of strategic choice between channeling spending to "growth-promoting expenditures" and social sectors i.e. between "directly and indirectly" productive sectors.

In the medium term, the focus will remain on prioritizing and sequencing the MKUKUTA interventions based on the on-going programs, activities, and strategies that have multiple effects. To maintain stability in the key economic variables, the budget will provide more resources for pro - poor growth enhancing expenditures with relatively higher import content.

In that regard, an increase in expenditures on infrastructure development relative to increases in social services is expected. Furthermore, strategies that address regional imbalances and mainstreaming cross-cutting issues will be considered favorably.

\subsection{Budget Execution}

A good strategy for financing MKUKUTA initiatives is critical for the achievement of the desired targets. Some of the targets can be achieved given that they are adequately resourced and that there is a proper mechanism in place to address fund mismanagement. The Government will spearhead efforts to increase collection of domestic resource, and mobilize DPs to scale up external assistance in line with international commitments and local realities and needs. The available resources will be used in a prudent manner for the intended purpose to ensure value for money.

While it is important to ensure timely release of funds for realization of the expected result, the challenge has been to ascertain the linkage between the use of funds and the actual result on the ground especially when it takes more than one year to be realized. In some of MKUKUTA indicators, it takes time to actually realize the impact of resource flow on the expected results although it is also important to know how long it should take. 
Fiscal developments during 2006/07 were broadly in line with the budget targets. Domestic revenues by the end of June 2007 were TShs 2,739,022 million, which is 11.3percent higher than the annual estimates of TShs 2,460,995 million. Better domestic revenue performance was due to among others, efficient tax administration and implementation of the FY 2006/07 tax measures.

Expenditure performance for the fiscal year 2006/07 was also broadly in line with the budget estimates. Total Expenditure to GDP ratio declined slightly from 26.1 percent in 2005/06, to 25.5 in 2006/07, but still consistent with the MKUKUTA objectives. Total expenditure for 2006/07 was Tshs. 4,761,700 million equivalent to 98 percent of the total estimate of shillings 4,850,588 million, compared to 94.4 percent in $2005 / 06$. The main reason for this shortfall is the inadequacy in capturing of donor assistance provided directly to project.

As regards release of funds to MDAs, the flow of funds to some MDAs is skewed towards specific months of the year. The release pattern differs from one Ministry to another, depending on the needs, as well as availability of resources. MOF has been releasing funds to MDAs on monthly basis based on MDAs' cash flow plan and funds availability. There was however, low release of funds compared to cash flow forecasts in the first quarter of 2006/07 for most MDAs itself resulting from inadequacies in cash flow planning by MDAs and resource inflow in the treasury.

With regard to development budget, the challenge is unpredictability and delay in capturing information related to development funds (most of which is financed by donors) against the approved estimates. For instance, in 2005/06, MAFSC received 47 percent of the total budgeted development resources, 12 percent of it disbursed in the first half of the year. MoEVT, on the other hand, received 32 percent in the same year, with 22 percent out of this amount recorded in the first half of the year. The corresponding development transfers were however better for MoHSW, at 81 percent of the total approved budget for the year and 43 percent during the first half of the year. For all three Ministries above, first quarter releases were dismal, at -6percent, 12 percent and 3 percent for agriculture, education and health, respectively. 
Budgeting is one thing, but the most critical issue is to ensure that resources are available for the implementation of activities identified under MKUKUTA. The timing of disbursement should be consistent with MDA's cash plan. While the Government is taking measures to increase domestic revenue and sustain the necessary social economic environment for poverty reduction, DPs are encouraged to adhere to their pledges in supporting development initiatives. The targets set for 2010 can be achieved given first the availability of resources (as projected), proper alignment of resources to conform with Government priorities, and timely release to the needy sectors.

\subsection{Budget Reporting and transparency}

\subsubsection{Status on budget reporting mechanisms}

There have been improvements overtime in budget reporting and transparency in Tanzania. Reporting requirements are stipulated in the Public Finance Act of 2001, which is operationalized through the government's accounting procedure manuals. Generally, the structure of the budget is based on international GFS standards. This necessities budget data transformation in moving from SBAS - based (MKUKUTA) resource allocation to GFS - based budget documentation, and vice versa for MKUKUTA based analysis of budget execution results. To facilitate, monitoring and execution, the Government is developing a framework for MKUKUTA - based analysis of budget execution results, which analysis shall be reported through the BERs. In the meantime, the policy link to budget execution is assessed through assessment of consistence between SBAS based allocations and actual expenditures (i.e. budget variations) and the impacts on poverty through the MKUKUTA Monitoring System.

Other reporting mechanisms in place include the quarterly execution reports published on Ministry of Finance website. This report gives the overall fiscal framework. The Ministry also has flash report on monthly basis using the IFMS, which contains information on funds committed and disbursed. Although these reports are timely, accessible, and useful, they need to be structured on the basis of programs and MKUKUTA for a better outlook. 


\subsubsection{Status on Report Coverage}

The intermediary (Q1-Q3) BERs cover Government finances on a cash basis, excluding direct to- project funding by DPs, and treats transfers to LGAs as expenditure. The analysis therein is constrained to the extent that some projects' expenditures are not covered while some LGAs expenditure is assumed premium. The existing system fails to match complexities introduced by multiple channels of funding programs at the district levels. These complexities in the budget process call for measures to rationalize the funds flow and ensure that the systems remains transparent. Thus, instituting classification and reporting mechanisms for compiling comprehensive fiscal information will be accorded more attention in the next year of MKUKUTA implementation. To facilitate the process, shareholders, particularly the development partners and beneficiary institutions, will need to adopt integrated approaches to funds flow and reporting.

The Government acknowledges the importance of routine reporting on MKUKUTA expenditure, and on progress made in reducing poverty. Measures are being taken by the Government working closely with other stakeholders to address the issue, including preparation of manual to be used by all MDAs for reporting on MKUKUTA, as well as linking the IFMS with the SBAS. The challenge has been reporting on expenditures by MKUKUTA clusters and targets. While such data are available within the Integrated Financial Management System (IFMS), linking the IFMS with the SBAS has remained the real challenge. The Government is working on a methodology that will allow a more efficient exchange of information between the tools, and facilitate timely SBAS based analysis of budget execution results.

\subsection{Other policies related to Government Budget}

\section{Joint Assistance Strategy}

In December, 2006, the Joint Assistance Strategy for Tanzania (JAST) was adopted by the government. The JAST is a result of a broad government led consultation process with development partners and non-state actors, and reflects the government position on rationalization and harmonization of donor support. The overriding objective being reducing further the transaction costs associated with different strategies and enhance national ownership and 
government leadership of the development agenda. Based on the JAST, the participating development partners have, in close consultation with the government, prepared a Joint Programming Document (JPD) fully aligned to the MKUKUTA objectives.

Building on the JAST and JPD, the government will address the problem of inadequate predictability of external assistance by leading joint analysis with development partners on alternative scenarios or expenditure and external financing aiming at a clear consensus on medium term strategy and expenditure plans prior to 2008/09 budget cycle. It is envisaged that this will facilitate scaling up of aid in pursuant to faster growth and poverty reduction.

\section{Pay Reform}

The Presidential Commission on Public Service Pay submitted its report in December, 2006 as envisaged, focusing on a medium term policy to relate government employment levels and their budgetary implications. The government is currently reviewing the Commission's recommendations against MKUKUTA implementation priorities and budgetary feasibility with a view to developing an updated medium term pay policy. 


\section{CHAPTER SIX: MONITORING AND EVALUATION}

\subsection{An Overview}

In 2001, the Government of Tanzania developed and implemented the Poverty Monitoring System (PMS). The system was reviewed in 2005/06 in order to monitor the implementation of MKUKUTA, which is broader, comprehensive and more outcome-focused than PRSP. The revised monitoring system is known as MKUKUTA Monitoring System (MMS). MMS which was approved by the Government through the MKUKUTA Technical Committee (TC) in February 2006 is built on the previous system. MKUKUTA Monitoring Master Plan is a working document that guides the implementation of the MMS.

Major changes that were incorporated in the MKUKUTA Monitoring System included the following:

(i) Consolidating the Steering Committee and Technical Committee into one Government committee, the MKUKUTA Technical Committee. Its role is to ensure the proper functioning of the MKUKUTA Monitoring System and the timely production of information from Technical Working Groups. It also has responsibility for informing the representational structures of Government (i.e. IMTC, Cabinet and Parliament) on progress and policy implications emerging from the monitoring system.

(ii) Introduction of three Technical Working Groups instead of four. The Survey and Census and Routine Data Technical Working Groups have been merged to reflect the mandate of the National Bureau of Statistics (NBS) in ensuring the quality of all official statistics. The merged TWG is now called Survey and Routine Data TWG. Research \& Analysis TWG and the Communications TWG remain, although the latter has been renamed for simplicity from Dissemination, Sensitization and Advocacy.

(iii) Strengthening alignment and linkages between national-level outcome monitoring and Government Strategic Planning, Budgeting and reporting systems.

\subsection{Implementation Status}

Implementation status of the MKUKUTA Monitoring System covers the period from 2005/06 and $2006 / 07$. This is due to the fact that $2005 / 06$ was a transition year where the system itself was under review; therefore much of the progress was not reported. 


\subsubsection{MKUKUTA Secretariat}

\section{Reviews:}

During 2005/07, MKUKUTA Secretariat coordinated the review of the Poverty Monitoring System, and the development of the MKUKUTA Monitoring System. The review process involved consultations and negotiations with a large number of stakeholders engaged in the system. As part of this, the national indicators were reviewed to broaden them from a focus on the priority sectors of the PRS to the three clusters of MKUKUTA. This also involved more consultation with MDAs and other stakeholders. The final list that has 84 indicators at national level draws largely from sectors and gives recognition to a much larger set of indicators in many MDAs. The challenge now is to strengthen the Management Information Systems of MDAs as well as LGAs in order to improve the quality of data and frequency of information.

\section{Coordination}

The MKUKUTA Secretariat facilitated the functioning of Technical Working Groups and the Technical Committee. An annual calendar of meetings of all committees and TWGs was agreed in early 2006. The Secretariat worked closely with TWGs to ensure meetings take place, and quality work plans and progress reports timely prepared. Further to this, the Secretariat ensured availability and proper management of funds to the TWGs.

Other achievement includes the strengthening of communication and networks between the Secretariat and other stakeholders. The up-graded electronic newsletter titled MKUKUTA HIGHLIGHTS has improved communications between the Secretariat and stakeholders. The newsletter is produced every two months from January 2006 and a new email contact address known as mkukutamonitoring@gmail.com with over 450 individuals and organizations has been established. In addition, a new website for MKUKUTA monitoring is now operational.

Throughout 2005-07, the Secretariat in collaboration with central ministries has been involved in the harmonization agenda of planning, budgeting and reporting within Government processes. Important accomplished task in relation to harmonization is the development of the Medium Term Strategic Planning, Budgeting and Reporting Manual. The manual articulates the linkages 
between MKUKUTA, Sector policies, Strategic Plans and MTEF frameworks, and assists institutions to plan, budget, monitor, and report, based on MKUKUTA.

MKUKUTA matrix was reviewed to facilitate seamless planning at MDAs level. The Strategic Budget Allocation System (SBAS), was also reviewed to capture the new features introduced by the planning manual, and incorporates the MKUKUTA cluster strategies. This facilitated MDAs and LGAs link their interventions with particular MKUKUTA goal via the budgeting process. To facilitate MKUKUTA reporting by institutions, the computer software known as RIMKU (Ripoti ya Utekelezaji wa MKUKUTA), was developed and work is ongoing to improve and harmonize RIMKU with other government software in order to ensure complementarities and reduce transaction costs.

The MKUKUTA Costing exercise is another important milestone, MKUKUTA Secretariat has coordinated. Key interventions from eight key sectors: health, education, water, roads, agriculture, land, energy and labor have been costed. The costing exercise is intended to establish cost estimates on an annual basis for five years and beyond, of the amount required for implementation of MKUKUTA.

\section{Consultation:}

The MKUKUTA secretariat has also coordinated development of Multi Sectoral Social Protection Framework. The process has been participatory where a broad range of stakeholders were consulted. Three levels of consultations were organized including the national level consultation where all MDAs participated; Sub national level consultation that involved all regions and districts; and Non State Actors level where Civil Society Organizations, Private Sectors, and Trade Unions participated. Consultation reports were consolidated and used to prepare draft version of Multi-Sectoral Social Protection Framework. The mapping exercise of Social protection interventions, and review of policies in the country is being carried out and once completed will inform the draft version of the National Multisectoral Social Protection Framework. The draft version will be used as an input to the final round of consultations, which is expected to be concluded between October and November, 2007.

\subsubsection{Research and Analysis Technical Working Group}

The Research and Analysis TWG is responsible for analysis of data, and coordinating outputs of national research that inform policy makers and stakeholders. The main output in 2005-07 was the production of third Poverty and Human Development Report, which included policy briefs in 
English and Kiswahili. The report provided for the first time analysis of key indicators at District level, determined through a poverty mapping methodology using the national census and household budget survey. In addition, the PHDR provided an overview of progress on key indicators and an analysis of rural growth. Producing analytical national reports requires commissioning and undertaking of a considerable amount of research, as well as networking.

In 2006, the first status report titled The Status Report (2006) was prepared based on the revised set of MKUKUTA indicators. Other achievements include coordination of Views of the People Study and open policy dialogue sessions where various study findings are shared among stakeholders. Various policy based studies have been commissioned to support policy making process.

\subsubsection{Survey and Routine Data TWG}

The Survey \& Routine Data TWG is responsible for oversight of national data from both surveys and routine administrative sources. In 2005/06, two of the TWGs were merged to bring the system of data oversight fully under the mandate of NBS as Secretariat. The TWG now has two sub-groups: Surveys and Routine Data. PMO-RALG is the co-chair of the Routine Data subgroup because the local government administration generates much of this data.

\section{Routine Data sub-group}

The Routine Data Group, prior to its merging with Surveys, focused on creating awareness of the monitoring system and routine data in particular. The process involved zonal workshops and sector consultations. Inputs informed the draft Routine Data System Strategy Paper. Most of the other activities in this TWG were delayed until the re-shaping of the group took place in early 2006.

The newly constituted TWG has begun by focusing on the development of the Tanzania Statistical Master Plan (TSMP). This is being led by a team chaired by NBS and focuses on improving statistical information especially for M\&E. It seeks to provide strategic directions for accelerating the development of statistical capacity and evidence-based policy formulation, planning and decision- making. The output will be a comprehensive document that identifies and 
prioritizes the country's data requirements. Work will be undertaken with all sectors to ensure they develop MDA statistical plans.

\section{Survey sub-group}

The Survey sub-group provides oversight to national surveys outlined in the Survey Calendar of the MKUKUTA Master Plan. In 2005-07 this sub-group conducted a significant number of key surveys, progress is as described below:

\section{Agriculture Sample Census (2002/03)}

The 2002/03 Agriculture Sample Census, the largest in sub-Saharan Africa neared its completion. A number of outputs were produced including the Crop Report, Livestock Report, Technical Report, Household conditions and Access to natural Resource Report. The printing of Regional Level 2003 Reports for Tanga, Dodoma, Morogoro, Iringa and Mara has been finalized. The remaining 16 Regional reports and other two national Level Reports (Large Scale Farms Report, and Gender Profile of the Agricultural Sector) will be completed by September 2007.

A dissemination application for the agriculture sample census dataset has been designed. This is a computer-based application putting together all produced tabulations for the agriculture sample census dataset. It provides easy and friendly access to the tables. It also gives an opportunity for an individual data user to carry out own cross tabulations on variables to facilitate district as well as regional comparisons for performance indicators. The major challenge has been the delay in production of the Reports. The main reason for the delays is due to the magnitude of the agriculture sample census data set, which is too large in both scope and subject. So it was very difficult for the planning team to exactly estimate the duration of the different activities during the planning stage.

\section{Integrated Labor Force Survey (ILFS)}

The 2006 Integrated Labor Force Survey (including Child Labor and Time-use modules) preparatory phase was completed by December 2006. The notable achievements as of June 2007 include completion of data collection, data input and processing, and preparation of list of 
indicators, dummy tables, data analysis and report writing. The draft report will be out by October 2007.

\section{Tanzania Service Provision Assessment Survey (TSPA)}

Implementation of the TSPA started in 2005/06 and continued in 2006/07 financial year. Achievements of the TSPA include completion of data collection, data processing and production and dissemination of Preliminary report. During 2006/07, evaluation study of the survey was also carried out and the final reports will be produced and disseminated by October 2007.

\section{6/07 Household Budget Survey (HBS)}

The implementation of the HBS started in April 2006, a bit late than expected. Much time was spent during the planning stage, to decide methods and sample to be employed. The HBS 2006/07 decided to administer a diary method, and to undertake recall on a sub sample basis as a test of its applicability. The sample was at National level with stratification of DSM, other urban areas, and rural. A number of activities have been accomplished including the completion of Pre testing and pilot testing, household listing exercise, Training of enumerators, administration of questionnaire, data processing and drafting of the report. The exercise is expected to be completed by December 2007.

\section{National Panel Survey (NPS)}

The NPS is a new initiative that follows individuals, households, communities, health and education facilities over time. By following respondents over time it may be possible to assess changes, including, the losses and gains of economic development. It will be used to evaluate the impact of TASAF II. The survey is still in a design stage, whereby questionnaires, sampling and data collection methodology are being scrutinized.

\section{Tanzania Disability Survey}

Implementation of the above survey is planned for financial year 2007/08. However, planning and preparations have been done in the just ended financial year in which the following activities were implemented as follows; Development of instruction manual and the three questionnaires (household, adult and children questionnaires); consultations with different stakeholders 
including organizations dealing with people with disabilities; Consultation and incorporation of views of stakeholders; Pre - test of the instruments and Preparations for the pilot test in Dodoma.

\section{Tanzania HIV/AIDS and Malaria Indicator Survey (THIS)}

Preparatory activities for the THIS survey was done in the 2006/07 financial year. The actual implementation of the survey will take place in the financial year 2007/08. The achievements in preparatory phase include completion of listing of households in the selected households and consultations meeting with stakeholders. Training of enumerators is scheduled to take place in September 2007, and the fieldwork will start after the training.

\section{Business Survey}

Physical execution of the survey started in May 2007. By the end of June, 2007, the following activities were carried out; Procurement of materials for the field work; Printing of questionnaires and manuals; Purchase of computers; Training of Trainers; Training of Regional Supervisors and Enumerators; and Enumeration exercise in all regions. About 85 percent of the enumeration work has been completed.

\section{Distributive Trade Survey (DTS)}

The implementation of the DTS started in the 2006/07. Planning, formation of steering committee and sampling design are the activities that have been started and are in progress.

\subsubsection{Communication TWG}

The Communication TWG is led by the Poverty Eradication Division in the Ministry of Planning, Economy and Empowerment. It continued with the work of creating awareness on the MKUKUTA framework and on the implications of major findings from MKUKUTA Monitoring System outputs in order to foster dialogue among stakeholders and support the implementation of MKUKUTA.

The Group employed an array of mechanism to engage and reach out to many stakeholders with the information. The MKUKUTA Monitoring Master Plan (MMP), which guides the implementation of MMS, was widely distributed. The MKUKUTA status Report 2006 was also 
shared with the members of parliament and other stakeholders. During the 45 Independence Anniversaries, the group disseminated all MMS outputs. To reach out to more audiences especially in the villages, Radio and TV programs, were used to disseminate messages and information on MKUKUTA and MDGs. Other channels and activities include the use of MKUKUTA calendars and seminars to Member of Parliament. The Group also worked very closely with Research Working Group in designing the planning and designing the views of the people study.

\subsection{Harmonization of National Processes with MAIR}

In Tanzania, the principles of development partnership relating to harmonization and alignment of aid modalities have been articulated in several documents including: Independent monitoring Group report, PER Evaluation Reports, Tanzania Assistance Strategy (TAS) and recently in Joint Assistance Strategy for Tanzania (JAST). The harmonization and alignment agenda has three main categories. First, is the development and use of a common framework for disbursement, accounting, reporting and performance appraisal. The framework is based on governmentestablished systems with aim of enhancing transparency and predictability of donor financing. Also, it aimed at improving reliability of donor disbursements in both timing and amount to improved planning and budgeting.

Second, the harmonization agenda also included addressing the disconnection between Sector Development Program and MKUKUTA. This implied that Sector development program and strategies had to be reviewed to ensure consistency with MKUKUTA and a strategic link between resource allocation and MKUKUTA.

Third, it also pointed to the need of harmonization and rationalization of national processes particularly the MKUKUTA Monitoring System, Public Expenditure Review and the MTEF/Budget Guideline. And to bring on board the GBS, PRSC and PSI as part and parcel of the national processes rather than being seeing as separate stand alone sub-processes.

With the advent of MKUKUTA based cluster outcome approach that counts on the contribution of all sectors towards growth and poverty reduction, several processes including the Public Expenditure Review (PER) process had to undergo significant reforms to reflect the desired goals and cluster outcomes linked to the budget process. It was stated in MKUKUTA that key 
processes would be sequenced and properly timed in order to provide adequate linkages and synergies among them. The MKUKUTA (and its monitoring system) feed into the PER process, which again informs the preparations of the budget guidelines. The budget guideline informs sectoral budgets and MTEF preparations. The importance of sector reviews as well as core reforms in MKUKUTA implementation cannot be over emphasized as part of the recent harmonization agenda. The JAST process was also meant to inform the PER process on external finance assistance among other things. In the recent past, the calendar of the key processes has been reviewed and harmonized.

On monitoring, the harmonization process has addressed issues of linkages of MKUKUTA Monitoring System with other monitoring systems at different levels such as MDAs and LGAs. Also, it has addressed the harmonization of output from MMS with PER.

\subsubsection{Progress on Harmonization Initiatives}

In 2006/07 an Inter Ministerial Taskforce on Planning, Budgeting and Reporting comprising of staff from Ministry of Planning, Economy and Empowerment (MPEE), Prime Ministers Office - Regional Administration and Local Government (PMO-RALG), President's Office - Public Service Management (PO-PSM) and Ministry of Finance (MoF) was formed. The objective of the task force was to rationalize and harmonize government reporting, monitoring and evaluation approaches.

Notable progress has been recorded in the harmonization agenda including rationalization of planning, budgeting monitoring and reporting processes and dialogue mechanism. For Government institutions, the planning, budgeting, monitoring, and reporting has been rationalized and documented in detailed and user friendly manual called "Medium Term Strategic Planning, Budgeting and Reporting Manual (MTSPBR)" produced by the Government in 2005. Explicit performance reporting requirements have been developed and were incorporated into the 2007/08 Plan and Budget Guidelines. These requirements specify a more analytical, reader friendly and accessible series of reports, which are consistency with MKUKUTA and other national reporting requirements. 
Within the manual, the role of MKUKUTA reporting is clearly spelt as the process of aggregating self reported performance information derived from MDAs and LGAs and supporting this information with independent surveys and analytical work. This is done through the production of two reports:-MAIR and PHDRs and status reports for those years which the PHDR is not produced. MDAs and LGAs performance reports are done on quarterly basis linked to MKUKUTA cluster outcomes through the new reporting system of RIMKU, as well as to Sector Reviews, Public Expenditure Reviews (PERs) and MDA and LGA audit reports.

The Government is committed to bringing these various reporting instruments closer together to inform each other and to strengthen the overall links to MKUKUTA and between planning, budgeting and reporting. Towards this, three softwares; PIMA, PLANREPII and RIMKU were assessed and decision made on the need to harmonize all the three software in order to support seamless reporting. Further improvement will be made to RIMKU in relation to PLANREPII, PIMA SBAS and IFMS in order to respond to the needs of all reports needed by stakeholders including MKUKUTA Annual Implementation Report (MAIR).

An independent study on Monitoring and Evaluation inventory across the government is currently on going in 27 MDAs. This study will provide an insight on the status of M\&E in MDAs in terms of capacity availability. Also, the study will inform decision makers on which steps and intervention needs to be taken in the development of M\&E policy and legal framework.

Further more, in order to facilitate cluster wide dialogue, a new dialogue structure has been designed. This brings together processes under GBS, PER and MKUKUTA together. The three secretariats:-GBS, PER and MKUKUTA Secretariats have been working together in implementing the harmonization agenda. Important events such as the PER annual consultative meetings and the Poverty Policy Week are now planned and organized in collaboration.

\subsection{Challenges and Lessons Learned}

A number of issues were noted during the implementation of the MKUKUTA Monitoring System. The shift from PRSP to MKUKUTA framework has broadened and deepened the monitoring agenda in terms of data collection, analysis and dissemination, and resources and management of the system. The expansion of indicators to more than 80 required more work on data collection (both routine and surveys), research and Analysis than during the PRSP. The 
outcome framework has called for participation of more institutions and players than during the PRSP. Emerging from this account is the need for a stronger Monitoring and reporting systems and clear links within and across Government and other key players and further consolidating accountability processes.

There are currently weak links between the MMS and the MDAs and LGAs Monitoring work. The MMS has so far little impacts on strengthening routine data systems or research work at the MDA level as well as the LGA level. Differences still remain between indicators used in MKUKUTA and, where exist, in MDA performance frameworks.

Despite MMS notable achievements in coordinating and producing important data, information and statistics for poverty monitoring and social development, much of its funding highly depends on external support. Over time, substantial contribution of resources to the pool fund has been from the Development Partners. This raises concerns on the sustainability issues of monitoring activities and the achievements recorded since the inception of PMS in 2001.

Though, groups were re-constituted in April 2006, orientations done for members, and an annual calendar of meetings agreed, there has been low attendance in the regular meetings, which sometimes affect implementation of planned activities. One of the reasons for poor attendance has been that TWG activities were not mainstreamed within the respective institutions, which are members to the TWG. One of the lessons learned is that many participants perceive their role as advisory, rather than functionary and assume the Secretariats will undertake the work. This creates some unrealistic expectations. Encouraging the accomplishment of practical tasks, rather than advice giving, may help.

\subsection{The way forward}

The government will continue with the harmonization of M\&E system in the government institutions for quality reporting and for better decision-making. It will also institutionalize M\&E functions within MDAs and LGAs so as to link it with MKUKUTA monitoring system. This will entail putting in place on M\&E policy, capacity building interventions at all levels that include 
improvement of RIMKU, PIMA, and PLANREP application software. Also training of MDAs and LGAs on RIMKU and PLANREP software will be conducted respectively.

In addressing the issue of funding, the Government will gradually implement the recommendations made in the mapping study for migrating MMS funding from Pool Fund to the Mainstream national budget. A Joint Task Force between the Government and Development Partners has been formed to identify critical issues, ranging from funding to those for strengthening the implementation of MMS to be addressed during the transition period, which goes up to 2012. 


\section{CHAPTER SEVEN: KEY ISSUES AND THE WAY FORWARD}

\subsection{Introduction}

The chapter brings to the fore key issues that underpin further improvements in achieving various MKUKUTA outcomes. It discusses and in some cases gives recommendation for the way forward on issues pertaining to growth and income poverty; social wellbeing and quality of life; governance and accountability; financing and issues related to monitoring and evaluation.

\subsection{Issues for Further Action}

Overall, it is important to further examine and strengthen linkages between sectors within each cluster for informing cluster level discussions. These linkages were recognized during the design and expected to be part of implementation of MKUKUTA. The achievement of MKUKUTA outcomes will be significant if the synergies generated through implementation are carefully taken on board.

Furthermore, processes for prioritization, sequencing and checking consistency between the interventions and the MKUKUTA expected outcomes require strengthening. Also, implementation modalities and capacities through community involvement and private-public partnership call for urgent scaling up.

\subsubsection{Growth and Poverty Reduction}

- Economic infrastructure is probably the single most binding factor for unleashing higher growth. In addition to reducing the costs of production, particularly for SMEs and agroprocessors, infrastructure investment depicts a higher absorption capacity needed for aid scaling up.

- Particular attention is required to enhance agriculture sector performance and promote more agro-processing. In addition, the financial constraints (credit facilities) to agriculture need concerted efforts to be reduced or eliminated all together. 
- During the last three years energy crisis manifested itself as a major threat to achievement of development results. It is important to explore alternative sources of energy - as per goal six of MKUKUTA.

- The progress on rural roads is not very encouraging. Efforts to step up resources and implementation should be part of the annual sector dialogue process in the next few weeks.

- Recent exogenous shocks (drought and high oil prices) have demonstrated the extent to which the economy is still vulnerable. Diversification, especially of exports and energy sources, and sufficient food reserves will be critical in building the economy's capacity to withstand and deal with shocks.

\subsubsection{Social Wellbeing and Quality of Life}

- Significant achievements have been made generally in the area of Social wellbeing and quality of life. However, in health related indicators, HIV/AIDS has undermined the impact of measures undertaken. Maternal mortality is one case in point. It has increased from 529/1000 to 578/1000 live birth despite concerted efforts. This poses a challenge. Measures needs to be scaled up as well as more innovative intervention, to reverse the upward trend. A related challenge is group dynamics in social relations (interactions between age groups), which calls for more protective interventions. On the other hand, given the immense impact on socio economic arena, efforts to prevent, treat and care needs to be scaled up.

- Unplanned settlements especially in urban centers have become a threat on urban environment. This area will require a more innovative and fast tracking measures including regularization of unplanned settlement.

- Recent studies has shown increasing burden on the elderly and an increasing number of orphans and children from poor households. These groups will require some kind of social protection intervention on one hand, but equally important to note is the supply side. The fiscal implication of cash transfer to these groups is huge, and therefore a need to target. Some work has to be done to determine affordability of social protection measure. 
- Human resource is central to achievement in any undertaking. Future development will very much depend on mass of well educated/trained masses in different fields. A big challenge here is balancing the human resource needs for improved social services something that requires a sustainable macro-fiscal framework, and thereafter create pressures for higher civil service pay.

\subsubsection{Governance and Accountability}

- The low capacity for LGAs to allocate, manage and account for resources call for further actions to improve their delivery capacities. In addition, auditing functions under the LGA require further strengthening. This is even more important after recent measures to accelerate implementation of D by D policy.

- The posting of information to the notice boards by LGA has not necessarily led to improved access and use by communities.

\subsubsection{MKUKUTA Financing}

- There is a need to align MDA's strategic plan with MKUKUTA so that resource allocation is effectively carried through to the plans

- Inadequacy of resources to finance MKUKUTA. This requires Government increasing domestic revenue on one hand, while development partners on the other hand need to scale up and harmonize aid delivery practices.

- Linking resource allocation to expected results and reporting will require further work of streamlining the SBAS and IFIMs.

- Inclusion of other players in the MKUKUTA implementation report contributing to poverty reducing efforts remains a challenge in the medium term.

\subsubsection{Monitoring and Evaluation}

- Improvement of the management information systems in MDAs and sectors, data collection, analysis and use require concerted efforts by all stakeholders. 
ANNEX 1: SUMMARY OF OUTCOMES, PERFORMANCE, AND CHALLENGES

\section{CLUSTER I: GROWTH AND REDUCTION OF INCOME POVERTY}

\section{Goal 1: Ensuring sound economic management}

\begin{tabular}{|c|c|c|c|}
\hline Outcome & Performance & Challenges \& Lessons & Way forward \\
\hline $\begin{array}{l}\text { - Annual Rate of Inflation } \\
\text { as percent of GDP } \\
\text { - Fiscal Deficit as percent of } \\
\text { GDP (before and after grants) } \\
\text { - External debt to export ratio } \\
\text { - Export as percent of GDP } \\
\text { (Official Foreign Reserves } \\
\text { - Unemployment }\end{array}$ & $\begin{array}{l}\text { - Annual rate of Inflation rose from } \\
5.9 \text { percent in } 2005 \text { to } 7.3 \text { percent in } \\
2006 \text {. } \\
\text { - Government domestic revenue (tax } \\
\text { and non-tax revenue) as a percent of } \\
\text { GDP increased from } 14.3 \text { percent in } \\
2005 / 06 \text { to } 15.6 \text { percent in } 2006 / 07 \text {. } \\
\text { - Fiscal deficit as percent of GDP; } \\
\text { before and after grants has been - } \\
11.5 \text { and -5.5 respectively. } \\
\text { - External debt services as percent of } \\
\text { exports declined from } 4.4 \text { percent to } \\
2.3 \text { percent in } 2005 \text { and } 2006 \\
\text { respectively. } \\
\text { - Exports as percent of GDP rose to } \\
21.9 \text { percent in } 2006 / 07 \text {. } \\
\text { The OFR declined to } 5.3 \text { months of } \\
\text { services }\end{array}$ & $\begin{array}{l}\text { - Over reliance on rainfall for agriculture and } \\
\text { for electricity production. } \\
\text { - Low productivity. } \\
\text { - Low economic growth. } \\
\text { - Inhibitive registration formalities } \\
\text { - Inadequate financial resources; } \\
\text { - narrow tax base } \\
\text { outdated labor laws } \\
\text { expansion of sectors i.e. education } \\
\text { - Over reliance on oil imports. } \\
\text { and protecting value of the Tanzania Shilling. } \\
\text { - The rapid growth of the informal sector }\end{array}$ & $\begin{array}{l}\text { - Exploring alternative } \\
\text { sources of energy. } \\
\text { - Stepped up involvement } \\
\text { of village communities } \\
\text { - Increased financing. } \\
\text { - self-employment } \\
\text { - Entrepreneurship. } \\
\text { More aggressive export } \\
\text { drive } \\
\text { implementing labor laws }\end{array}$ \\
\hline
\end{tabular}

92

CInternational Monetary Fund. Not for Redistribution 
- The unemployment rate declined

from 12.9 percent in 2005 to 11 percent in year 2006

- A total of 27,244 enterprises were given loans countrywide through National Empowerment Funds for the purpose of reducing unemployment and income poverty.

\section{Goal 2: Promoting sustainable and broad-based growth}

\begin{tabular}{|c|c|c|c|}
\hline Outcome & Performance & Challenges \& Lessons & Way forward \\
\hline $\begin{array}{l}\text { - Interest rate spread on lending } \\
\text { and deposits }\end{array}$ & $\begin{array}{l}\text { - Domestic credit to private sector as } \\
\text { percent of GDP increased from } 11 \\
\text { percent in } 2005 \text { to } 12.5 \text { percent in } \\
\text { year } 2006 \text {. } \\
\text { - Percentage of foreign direct } \\
\text { investments declined from } 7 \text { percent } \\
\text { in year } 2005 \text { to } 6 \text { percent in year } \\
2006 \text {. } \\
\text { - Interest rate spread increased from } \\
12.0 \text { percent in year } 2005 \text { to } 13.3 \\
\text { percent in year } 2006 \text {. }\end{array}$ & $\begin{array}{l}\text { - } \text { Budget constraint. } \\
\text { - } \text { Optimal utilization of sector capacity. } \\
\text { - } \quad \text { Increase value addition of minerals before } \\
\text { exportation } \\
\text { - } \quad \text { Unreliable flow of external resources. } \\
\text { - The need of scaling up irrigation } \\
\text { - } \quad \text { Enhriculture system. } \\
\text { in agriculture }\end{array}$ & - Increase R\&D activities. \\
\hline
\end{tabular}




\begin{tabular}{|c|c|c|c|}
\hline Outcome & Performance & Challenges \& Lessons & Way forward \\
\hline $\begin{array}{l}\text { - Food self sufficiency ratio } \\
\text { (rate) } \\
\text { - Proportion of districts reported } \\
\text { to have food shortages ( } \\
\text { percent) } \\
\text { - Increased food crops } \\
\text { production from } 9 \text { millions } \\
\text { tons in 2003/4 to } 12 \text { millions } \\
\text { tons by } 2010 \\
\text { - Maintained Strategic Grain } \\
\text { Reserve (SGR) of at least } 4 \\
\text { month of national food } \\
\text { requirement }\end{array}$ & $\begin{array}{l}\text { - The food self sufficiency rate } \\
\text { increased from } 103 \text { in year } 2005 \text { to } \\
112 \text { in year } 2006 \text {. } \\
\text { - The proportion of districts reported } \\
\text { to have faced food shortage } \\
\text { increased from } 41 \text { percent to } 50 \\
\text { percent in year } 2005 \text { and } 2006 \\
\text { respectively. } \\
\text { - Production of food crops reached } \\
10.9 \text { millions tons in } 2005 / 06 \\
\text { - Percentage increase in food } \\
\text { production }\end{array}$ & $\begin{array}{l}\text { Drought } \\
\text { Outbreak of armyworms. } \\
\text { Post harvest management techniques are required. } \\
\text { The need to improve flow of market information }\end{array}$ & $\begin{array}{l}\text { Establish highly } \\
\text { mechanized irrigation } \\
\text { systems. } \\
\text { Provide subsidized seeds } \\
\text { and agro chemicals. }\end{array}$ \\
\hline
\end{tabular}

\section{Goal 4 \& 5: Reducing income poverty of both men and women in urban and rural areas}

\begin{tabular}{|l|l|l|l|}
\hline Outcome & Performance & Challenges \& Lessons \\
\hline - Percentage of smallholders & Increased cattle export earnings to & $\bullet$ High cost of renewable energy \\
participating in contracting & Tshs 2.9 billion & Pilferages, thefts, sabotage of power \\
production and out grower's & $\begin{array}{l}\text { Rural Electrification Master Plan } \\
\text { infrastructure } \\
\text { schemes }\end{array}$ & finalized & insufficient technical capacity \\
\hline
\end{tabular}




\begin{tabular}{|c|c|c|c|}
\hline Outcome & Performance & Challenges \& Lessons & Way forward \\
\hline $\begin{array}{l}\text { - Total smallholder land } \\
\text { irrigation as a percent of total } \\
\text { cultivatable land. } \\
\text { Percentage of smallholder } \\
\text { households who have one or } \\
\text { more off-farm income } \\
\text { generating activities } \\
\text { Percentage of households } \\
\text { whose main income is derived } \\
\text { from the harvesting, processing } \\
\text { and marketing of natural } \\
\text { resource products. }\end{array}$ & $\begin{array}{l}\text { - 4,567 FDC trainees trained in life } \\
\text { skills and entrepreneurship skills } \\
\text { - Increase in number of SACCOS and } \\
\text { members; increase in total loans by } \\
\text { T.Shs } 11.6 \text { billion (about } 20 \text { percent) }\end{array}$ & high cost of borrowing & $\begin{array}{l}\text { sector in the } \\
\text { implementation of } \\
\text { rural energy projects }\end{array}$ \\
\hline
\end{tabular}

\section{Goal 6: Provision of reliable and affordable energy to consumers}

\begin{tabular}{|c|c|c|c|}
\hline Outcome & Performance & Challenges \& Lessons & Way forward \\
\hline $\begin{array}{l}\text { - Liberalization of Power sub } \\
\text { sector effected by } 2010 \\
\text { - At least three (3) Production } \\
\text { Sharing Agreements (PSA) } \\
\text { negotiated, concluded and } \\
\text { signed by June } 2010\end{array}$ & $\begin{array}{l}\text { - Secured funds for electrifying } \\
\text { remaining district headquarters } \\
\text { - Percentage increase in the number } \\
\text { of customers connected to the } \\
\text { national grid and off grid sources of } \\
\text { electricity } \\
\text { - Signed three Agreements for }\end{array}$ & $\begin{array}{l}\text { - Diversification of energy sources } \\
\text { - } 2006 \text { power crisis: need for diversifying energy } \\
\text { sources } \\
\text { - conflicts over energy resource use (sources, etc) }\end{array}$ & $\begin{array}{l}\text { - Promotion of regional } \\
\text { cooperation in the } \\
\text { energy sector } \\
\text { - Implementation of the } \\
\text { Power Sector Master } \\
\text { Plan (PSMP) } \\
\text { - Continued publication }\end{array}$ \\
\hline
\end{tabular}


- Nineteen PSAs negotiated and acreages offshore, concluded

- Launched Website for information basins

\section{CLUSTER II: IMPROVEMENT OF QUALITY OF LIFE AND SOCIAL WELL BEING}

Goal 1: Ensuring equitable access to quality primary and secondary education for boys and girls, universal literacy among men and women and expansion of higher, technical and vocational education.

\begin{tabular}{|c|c|c|c|}
\hline Outcome & Performance & Challenges \& Lessons & Way forward \\
\hline $\begin{array}{l}\text { - Increased gross and net } \\
\text { enrolment of boys and girls in } \\
\text { primary schools from } \\
\text { 90.5percent in } 2004 \text { to } \\
\text { 99percent in } 2010\end{array}$ & $\begin{array}{l}\text { - Total enrolment has increased from } \\
669,137 \text { in } 2006 \text { to } 794,011 \\
\text { (18percent) in } 2007 \text {. } \\
\text { - Net enrolment at Pre primary level } \\
\text { of } 5 \text { to 6years old children } \\
\text { increased from } 24.6 \text { percent in } 2004 \\
\text { to } 28.5 \text { percent in } 2006\end{array}$ & $\begin{array}{l}\text { - overcrowded classes: number of classrooms } \\
\text { still inadequate, in most recently built } \\
\text { community secondary schools } \\
\text { - Inadequate number of qualified teachers } \\
\text { - Insufficient number of teachers' houses, desks, } \\
\text { toilets with full identification of children with } \\
\text { disabilities through strengthened EMIS } \\
\text { - Reaching the target of enrolling } 100 \text { percent of } \\
\text { children aged } 5 \text { and } 6 \\
\text { - Expand education facilities to meet } \\
\text { requirements }\end{array}$ & 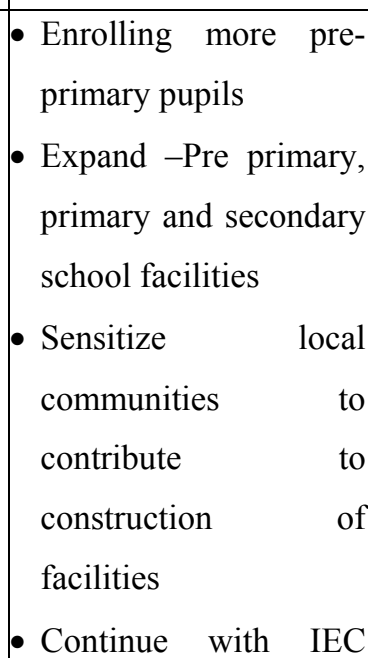 \\
\hline
\end{tabular}




\begin{tabular}{|c|c|c|c|}
\hline Outcome & Performance & Challenges \& Lessons & Way forward \\
\hline $\begin{array}{l}\text { - Increased proportion of children } \\
\text { with disabilities enrolled, attend in } \\
\text { and completing schools from } \\
0.1 \text { percent in } 2000 \text { to } 20 \text { percent in } \\
2010 \\
\text { - Increased proportion of orphans } \\
\text { and most vulnerable children } \\
\text { enrolled, attending and completing } \\
\text { primary education from } 2 \text { percent } \\
\text { in } 2000 \text { to } 30 \text { percent in } 2010 \\
\text { - Increased percentage of girls and } \\
\text { boys with disabilities and OVCs } \\
\text { who qualify for secondary } \\
\text { education enrolled and complete } \\
\text { secondary schools by } 2010\end{array}$ & $\begin{array}{l}\text { children with disabilities rose from } \\
77.6 \text { percent and } 59.0 \text { percent in } \\
2000 \text { to } 114.4 \text { percent and } 97.3 \\
\text { percent in } 2007 \text {. } \\
\text { - A total number of } 748,641 \text { orphans } \\
\text { have been enrolled in } 2007 \text {. } \\
\text { - Enrolment of children with } \\
\text { disabilities into secondary schools } \\
\text { has increased by } 12.17 \text { percent from } \\
130 \text { ( } 72 \text { boys and } 58 \text { girls) in } 2005 \\
\text { to } 150 \text { (81 boys and } 69 \text { girls in } \\
2006 \text { ). }\end{array}$ & $\begin{array}{l}\text { - Overcrowding of pupils particularly in Urban } \\
\text { areas } \\
\text { - Low ability to absorb all school age going pupils } \\
\text { in Standard one } \\
\text { - Low Supervision capacity of LGAs } \\
\text { - Commitment is required of all stakeholders } \\
\text { Many primary schools do not have teachers' } \\
\text { houses } \\
\text { - In some localities communities were reluctant } \\
\text { to provide financial and physical contribution } \\
\text { Some teachers are reluctant to work in specific } \\
\text { regions }\end{array}$ & $\begin{array}{l}\text { campaign to create } \\
\text { awareness among the } \\
\text { public on their roles } \\
\text { and responsibilities to } \\
\text { create sprit of working } \\
\text { together to address } \\
\text { common problems } \\
\text { Build more } \\
\text { classrooms, teacher } \\
\text { houses, offices and pit } \\
\text { latrine }\end{array}$ \\
\hline $\begin{array}{l}\text { - At least } 50 \text { percent of boys and } \\
\text { girls aged } 14-17 \text { years are } \\
\text { enrolled in ordinary level } \\
\text { secondary schools by } 2010\end{array}$ & $\begin{array}{l}\text { - } 318,739 \text { boys and } 338,540 \text { girls of } \\
\text { age } 14-17 \text { (total } 657,279 \text { equivalent } \\
\text { to } 68 \text { percent) enrolled in form } 1-4 \\
\text { in } 2007 \text {. } \\
\text { - The number of students registered } \\
\text { for form one secondary education } \\
\text { increased from } 243,359 \text { in } 2006 \text { to }\end{array}$ & $\begin{array}{l}\text { - Educational facilities required to match with the } \\
\text { fast growing enrolments } \\
\text { - Achieving a sufficient number of classrooms, } \\
\text { teachers' houses, desks, toilets with adequate } \\
\text { water supply and sport facilities and equipment } \\
\text { for eligible children in school affairs. }\end{array}$ & $\begin{array}{l}\text { - Expand schools } \\
\text { facilities } \\
\text { Enroll more } \\
\text { pupils in the next } \\
\text { coming years. }\end{array}$ \\
\hline
\end{tabular}




\begin{tabular}{|c|c|c|c|}
\hline \multirow[t]{2}{*}{ Outcome } & Performance & Challenges \& Lessons & Way forward \\
\hline & $\begin{array}{l}\text { 401,011 in } 2007 \text { equivalent to an } \\
\text { increase of } 5 \text { percent. } \\
\text { - Fees relief for } 417,712 \text { students for } \\
\text { 1,694 day schools was provided. } \\
\text { - Manage to sponsor } 33,865 \text { form I- } \\
\text { IV students whose parents are } \\
\text { unable to send them to school. } \\
\text { - } 147 \text { girls form I-IV students who } \\
\text { obtained sponsorship under the } \\
\text { GSES program that was ended in } \\
\text { year } 2003 \text { have been covered under } \\
\text { the special fund under the sector } \\
\text { Ministry. }\end{array}$ & - Community need to be sensitized & teachers \\
\hline $\begin{array}{l}\text { - At least } 60 \text { percent of girls and } \\
\text { boys pass Standard VII } \\
\text { examinations by } 2010\end{array}$ & $\begin{array}{l}\text { - The pass rate of final Primary } \\
\text { School National Examinations } \\
\text { (Standard VII) has improved from } \\
22 \text { percent in } 2000 \text { to } 70.5 \text { percent } \\
\text { in } 2006 . \\
\text { - In year } 2007,80 \text { percent }(468,279) \\
\text { of boys and girls passed standard } \\
\text { VII examinations. } \\
\text { - Transition rate from primary to } \\
\text { secondary school has increased }\end{array}$ & $\begin{array}{l}\text { - To ensure education quality simultaneously } \\
\text { couple with the increased number of qualified } \\
\text { students. } \\
\text { - Expansion of chances and facilities in } \\
\text { secondary levels to cope with higher enrolments } \\
\text { - Still few are joining secondary schools }\end{array}$ & $\begin{array}{l}\text { - Construct more classes } \\
\text { and teachers' houses } \\
\text { - Increase number of } \\
\text { schools in each region }\end{array}$ \\
\hline
\end{tabular}




\begin{tabular}{|c|c|c|c|}
\hline Outcome & Performance & Challenges \& Lessons & Way forward \\
\hline & $\begin{array}{l}\text { from } 36.1 \text { percent in } 2005 \text { to } 67.5 \\
\text { percent in } 2006 \text {. The girls increase } \\
\text { was from } 35.6 \text { to } 65.2 \text { percent and } \\
\text { boys from } 36.6 \text { to } 69.8 \text { in } 2005 \text { to } \\
2006 \text { respectively. }\end{array}$ & & \\
\hline $\begin{array}{l}\text { - At least } 25 \text { percent of boys and } \\
\text { girls are enrolled in advanced } \\
\text { level secondary schools by } \\
2010 \\
\text { - Achieving an average attendance } \\
\text { in primary schools of at least } \\
\text { 85percent }\end{array}$ & $\begin{array}{l}\text { - The gross enrolment of students in } \\
\text { both public and private secondary } \\
\text { increased from } 55,134 \text { in } 2005 / 06 \\
\text { to } 75,346 \text { in year } 2006 / 07 \text {. The } \\
\text { percent of boys and girls enrolled at } \\
\text { Advanced Secondary schools stands } \\
\text { as } 65 \text { percent and } 35 \text { percent } \\
\text { respectively. } \\
\text { - In year } 2007 \text { a total of number of } \\
33,088 \text { (19.1percent) boys and girls } \\
\text { enrolled in form five. } \\
\text { - Improve attendance in primary } \\
\text { school from } 77.5 \text { percent in year } \\
2003 \text { to } 81.0 \text { percent in year } 2006 \text {. }\end{array}$ & $\begin{array}{l}\text { - Achieving a sufficient provision of classrooms, } \\
\text { teachers' houses, desks, toilets with adequate } \\
\text { water supply and sport facilities and equipment } \\
\text { to enhance access and quality participation of } \\
\text { all eligible children in school affairs } \\
\text { - Financing gap for both PEDP and SEDP } \\
\text { programmes } \\
\text { - All education facilities need to be developed as } \\
\text { complete package }\end{array}$ & $\begin{array}{l}\text { - Expand enrolment } \\
\text { - Increase girl students } \\
\text { in secondary schools } \\
\text { Mobilize private sector } \\
\text { to invest in education }\end{array}$ \\
\hline $\begin{array}{l}\text { - At least } 90 \text { percent of cohort } \\
\text { complete standard VII }\end{array}$ & $\begin{array}{l}\text { - The percent of cohort completed } \\
\text { standard VII has improved from } \\
68.1 \text { in year } 2002 \text { to } 78.0 \text { in } 2006 \text {. }\end{array}$ & $\begin{array}{l}\text { - Repetition caused by Standard IV examinations } \\
\text { is the main contributing factor to this situation. }\end{array}$ & $\begin{array}{l}\text { - More awareness } \\
\text { campaign among the } \\
\text { parents. }\end{array}$ \\
\hline
\end{tabular}




\begin{tabular}{|c|c|c|c|}
\hline Outcome & Performance & Challenges \& Lessons & Way forward \\
\hline $\begin{array}{l}\text { - At least 70percent of girls and } \\
\text { boys pass at Division I-III in Form } \\
\text { IV examinations. }\end{array}$ & $\begin{array}{l}\text { - } 35.7 \text { percent of boys and girls } \\
\text { passed at Division I-III in } 2006 \text {. }\end{array}$ & $\begin{array}{l}\text { - Pregnancy and early marriages has continued to } \\
\text { exist in some areas particularly in rural areas. } \\
\text { - Awareness of Education among the parents has } \\
\text { increased }\end{array}$ & \\
\hline $\begin{array}{l}\text { - Improved learning } \\
\text { environment for all children in } \\
\text { all schools with all education } \\
\text { institutions safe, violence free, } \\
\text { child friendly and gender } \\
\text { sensitive }\end{array}$ & $\begin{array}{l}\text { - Increased number of both primary } \\
\text { and secondary schools from } 11,624 \\
\text { and } 927 \text { in } 2000 \text { to } 14,700 \text { and } \\
2,274 \text { in } 2006 / 07 \text { respectively. } \\
\text { - Construction of } 2,303 \text { classrooms } \\
\text { which is } 167.8 \text { percent of the } \\
\text { intended } 860 \text { classrooms. } \\
\text { - 2,183 teachers' houses constructed } \\
\text { which is } 336.6 \text { percent of the } \\
\text { projected } 500 \text { houses. } \\
\text { - Provision of lunch and water } \\
\text { services to pupils in } 622 \text { under } \\
\text { Child-Friendly Schools Programme } \\
\text { implemented in Kisarawe, Masasi, } \\
\text { Songea , Musoma, Ngara and } \\
\text { Makete. } \\
6,863 \text { pit latrines has been } \\
\text { constructed, } 9,120\end{array}$ & $\begin{array}{l}\text { - However, more efforts are needed to make the } \\
\text { environment safe, child friendly and gender } \\
\text { sensitive } \\
\text { - Good school environment is critical for } \\
\text { attaining education objectives }\end{array}$ & $\begin{array}{l}\text { - More conducive } \\
\text { environment in } \\
\text { schools to be created } \\
\text { for existing schools } \\
\text { and newly constructed } \\
\text { schools }\end{array}$ \\
\hline
\end{tabular}




\begin{tabular}{|c|c|c|c|}
\hline Outcome & Performance & Challenges \& Lessons & Way forward \\
\hline & $\begin{array}{l}\text { construction } \\
160,222 \text { desks fabricated }\end{array}$ & & \\
\hline $\begin{array}{l}\text { - } 90 \text { percent of primary and } \\
\text { secondary schools have } \\
\text { adequate numbers of } \\
\text { competent and skilled teachers } \\
\text { by } 2010 \text {. }\end{array}$ & $\begin{array}{l}\text { - } 50,813 \text { under qualified primary } \\
\text { school teachers have been up- } \\
\text { graded to attain Grade IIIA which is } \\
\text { the minimum qualification for } \\
\text { primary school teachers. } \\
\text { - Implementation of a crash program } \\
\text { of teaching methodology for } 6,000 \\
\text { qualified graduated form six } \\
\text { students. } \\
\text { - } 645 \text { teachers have been sponsored } \\
\text { for higher learning courses. } \\
\text { - } 150 \text { research work and publications } \\
\text { were sponsored. } \\
\text { - } 450 \text { secondary school head } \\
\text { teachers and } 103 \text { districts secondary } \\
\text { school coordinators have been } \\
\text { undergone management courses in } \\
\text { various institutions } \\
\text { - Implementation of the program for }\end{array}$ & $\begin{array}{l}\text { - Training, recruiting and retaining adequate } \\
\text { number of qualified teachers both for regular } \\
\text { students, pupils with special learning needs and } \\
\text { those for sports } \\
\text { - Crash program of teaching methodology to } \\
\text { teachers improve pupils' teacher ratio }\end{array}$ & $\begin{array}{l}\text { Expand enrolment of } \\
\text { teachers in teachers } \\
\text { colleges }\end{array}$ \\
\hline
\end{tabular}




\begin{tabular}{|c|c|c|c|}
\hline Outcome & Performance & Challenges \& Lessons & Way forward \\
\hline & $\begin{array}{l}\text { Construction of } 2 \text { laboratories in } \\
\text { one school in each region; and } \\
\text { libraries for } 30 \text { public schools. }\end{array}$ & & \\
\hline $\begin{array}{l}\text { - Primary and secondary } \\
\text { education is of a high quality } \\
\text { and promotes the acquisition of } \\
\text { critical knowledge, real skills } \\
\text { and progressive values. }\end{array}$ & $\begin{array}{l}\text { - Teaching methodologies have been } \\
\text { improved to adopt participatory } \\
\text { methods and child-friendly } \\
\text { techniques; } \\
\text { - National average book-pupil ratio } \\
\text { (BPR) has improved from 1:20 in } \\
2002 \text { to 1:3 in 2006; } \\
\text { - Teacher-pupil ratio (TPR) has } \\
\text { decreased from 1:58 in 2005 to 1:52 } \\
\text { in } 2006 \text {; } \\
\text { - Pass rate for Std IV examinations } \\
\text { increased from } 85 \text { percent in } 2004 \\
\text { to } 87.9 \text { percent in year 2006; } \\
\text { - The Primary School Leaving } \\
\text { examinations (PSLE) pass rate }\end{array}$ & $\begin{array}{l}\text { More schools especially community secondary } \\
\text { schools face shortage of teachers and } \\
\text { facilities.Quality control for private schools is } \\
\text { important }\end{array}$ & $\begin{array}{l}\text { - Training of teachers to } \\
\text { be intensified and } \\
\text { expanded to meet the } \\
\text { demand }\end{array}$ \\
\hline
\end{tabular}




\begin{tabular}{|c|c|c|c|}
\hline Outcome & Performance & Challenges \& Lessons & Way forward \\
\hline & $\begin{array}{l}\text { increased from } 48.7 \text { percent in } 2004 \\
\text { to } 61.8 \text { percent in } 2005 \text {. }\end{array}$ & & \\
\hline $\begin{array}{l}\text { - Effective HIV and AIDS } \\
\text { education, environment and } \\
\text { life skills programs in all } \\
\text { primary, secondary schools and } \\
\text { teachers colleges. }\end{array}$ & $\begin{array}{l}\text { - 2,650 primary school teachers have } \\
\text { attended training related to } \\
\text { HIV/AIDS pandemic. } \\
\text { - HIV/AIDS guidelines for Primary } \\
\text { Schools are in place }\end{array}$ & $\begin{array}{l}\text { - Mitigation of HIV/AIDS including, provision of } \\
\text { care and support to education personnel and } \\
\text { students affected by HIV/AIDS. } \\
\text { - Mainstreaming HIV/AIDS in schools is } \\
\text { effective in combating infection }\end{array}$ & $\begin{array}{l}\text { - The need to intensify } \\
\text { HIV and AIDS } \\
\text { campaign }\end{array}$ \\
\hline $\begin{array}{l}\text { - At least } 80 \text { percent of adults, } \\
\text { especially women in rural } \\
\text { areas, are literate } \\
\text { - Reduce the number of young } \\
\text { people involved in COBET }\end{array}$ & $\begin{array}{l}\text { - Number of illiterate adults has gone } \\
\text { down from } 3.8 \text { million in } 2004 / 05 \\
\text { to } 1.5 \text { million in } 2007 \text {. } \\
\text { - } 185,206 \text { COBET learners in } \\
\text { COHORT I-II in 2006/07. }\end{array}$ & $\begin{array}{l}\text { - Ensuring increased literacy rates among adults, } \\
\text { expanding vocational education, training to } \\
\text { promote self-employment } \\
\text { - Adult illiterate campaign need more efforts }\end{array}$ & $\begin{array}{r}\text { - Intensify the adult } \\
\text { literacy campaign }\end{array}$ \\
\hline $\begin{array}{l}\text { - Increased enrolment in higher } \\
\text { and technical education, } \\
\text { Universities and Technical } \\
\text { Colleges to } 50,000 \text { full time } \\
\text { students, } 15,000 \text { part time and } \\
25,000 \text { distance learners by } \\
2008\end{array}$ & $\begin{array}{l}\text { - Total number of students enrolled } \\
\text { in higher learning institutions rose } \\
\text { from } 55,134 \text { to } 75,346 \text { for the } \\
\text { academic year } 2005 / 06 \text { to } 2006 / 07 \\
\text { which is } 36.7 \text { percent. Percentage of } \\
\text { female to male was } 35 \text { and } 65 \\
\text { respectively. }\end{array}$ & $\begin{array}{l}\text { - -To enroll all students who are eligible for } \\
\text { joining universities } \\
\text { - -Expand loan fund capacity } \\
\text { - Introduction of NTA and phasing out of FTC at } \\
\text { DIT, TCA and MIST } \\
\text { - Introduced access courses for female students at } \\
\text { Universities and Technical colleges } \\
\text { - Introduced special scholarships for female }\end{array}$ & $\begin{array}{l}\text { - Encourage private } \\
\text { sectors to assist } \\
\text { qualified students to } \\
\text { join university } \\
\text { - Expand number of } \\
\text { universities } \\
\text { countrywide } \\
\text { - Strengthen Higher }\end{array}$ \\
\hline
\end{tabular}

104 


\begin{tabular}{|c|c|c|c|}
\hline Outcome & Performance & Challenges \& Lessons & Way forward \\
\hline & $\begin{array}{l}\text { - } 51,772 \text { students in year } 2006 / 07 \\
\text { accessed loans vis-à-vis } 42,729 \text { in } \\
\text { the previous years } 2005 \text {. } \\
\text { - The percentage of technical } \\
\text { institutions has increased from } \\
4,437 \text { in } 2000 / 01 \text { to } 10,567 \text { in } \\
2005 / 06 \text { Established University } \\
\text { Colleges of Education (Dar es } \\
\text { Salaam and Mkwawa), Dodoma } \\
\text { University }\end{array}$ & $\begin{array}{l}\text { students at UDSM } \\
\text { - Loan and University facility needs expansion }\end{array}$ & $\begin{array}{l}\text { Education Students } \\
\text { Loan Board. } \\
\text { - Sensitize private sector } \\
\text { to finance higher } \\
\text { education. } \\
\text { - Rationalization of } \\
\text { tertiary institutions. } \\
\text { - Expand physical } \\
\text { resources for teaching } \\
\text { and learning } \\
\text { Increase funding to } \\
\text { Tanzania Commission } \\
\text { for Universities and } \\
\text { National Council for } \\
\text { Technical Education. }\end{array}$ \\
\hline
\end{tabular}




\begin{tabular}{|c|c|c|c|}
\hline Outcome & Performance & Challenges \& Lessons & Way forward \\
\hline $\begin{array}{l}\text { - Reduce proportion of children } \\
\text { in labour country wide from } 25 \\
\text { percent to less than } 10 \text { percent } \\
\text { by } 2010 \text { and avail to them } \\
\text { alternatives including } \\
\text { enrolment in primary } \\
\text { education, COBET and } \\
\text { employable vocational } \\
\text { educational skills training. }\end{array}$ & $\begin{array}{l}\text { - } 86 \text { CDOs at LGAs and } 15 \text { tutors } \\
\text { have been trained on child rights so } \\
\text { as to disseminate the knowledge to } \\
\text { the community. } \\
\text { - In absolute terms a total no. of } \\
2,129 \text { students succeeded to pass } \\
\text { standard VII exams and joined } \\
\text { formal education in year } 2006 / 07 \text {. }\end{array}$ & $\begin{array}{l}\text { - Inadequate funds and shortage of manpower. } \\
\text { - Poverty at family level denies children with } \\
\text { basic needs .e.g. education, health and safety } \\
\text { needs. } \\
\text { - Lack of effective micro and area-based schemes } \\
\text { for disaster preparedness } \\
\text { - Current schemes for disaster preparedness are } \\
\text { not well known by many people. } \\
\text { - Difficulties in testing and declaring on health } \\
\text { status. }\end{array}$ & $\begin{array}{l}\text { To continue educating } \\
\text { communities in child } \\
\text { rights through CDOs at } \\
\text { LGAs and conduct } \\
\text { researches on } \\
\text { identifying the } \\
\text { magnitude of the } \\
\text { problems and setting } \\
\text { the means of solving } \\
\text { them. }\end{array}$ \\
\hline $\begin{array}{l}\text { - Reduced Vulnerability to } \\
\text { environmental disaster }\end{array}$ & $\begin{array}{l}\text { - } 493 \text { water resource points have } \\
\text { been inspected to examine water } \\
\text { pollutants and environmental } \\
\text { degradation agents. } \\
\text { - Implementation of the RWSSP } \\
\text { Project. } \\
\text { - Development of a draft bill of } \\
\text { Occupation Health and Safety } \\
\text { Policy. }\end{array}$ & $\begin{array}{l}\text { - People are not ready to be open in expressing } \\
\text { their health status due to prevalence of stigma. } \\
\text { - Inadequate number of CDOs at district level } \\
\text { who deals with orphans and vulnerable groups.. } \\
\text { - Stereotype behavior and income poverty hinder } \\
\text { the inclusiveness of the vulnerable groups in } \\
\text { accessing social facilities. }\end{array}$ & $\begin{array}{l}\text { To educate } \\
\text { communities on } \\
\text { disaster preparedness } \\
\text { and mitigation. }\end{array}$ \\
\hline
\end{tabular}




\begin{tabular}{|c|c|c|c|}
\hline Outcome & Performance & Challenges \& Lessons & Way forward \\
\hline $\begin{array}{l}\text { - Increased knowledge of HIV } \\
\text { /AIDS transmission in the } \\
\text { general population. Reduce } \\
\text { HIV/AIDS stigmatizations }\end{array}$ & $\begin{array}{l}\text { - Increase of counseling stations from } \\
806 \text { in year } 2005 / 06 \text { to } 1,027 \text { in } \\
\text { year } 2006 / 07 \text { while a total number } \\
\text { of } 2,739 \text { councilors have been } \\
\text { attending HIV and AIDS related } \\
\text { courses and trainings. } \\
\text { - A total number of } 849,334 \text { people } \\
\text { have been counseled. } \\
\text { - HIV Training modules for FDCs } \\
\text { have been prepared. }\end{array}$ & & $\begin{array}{l}\text { Harmonize HIV/AIDS } \\
\text { activities conducted by } \\
\text { MDAs, LGAs, NSAs } \\
\text { and others in combating } \\
\text { the pandemic. }\end{array}$ \\
\hline
\end{tabular}




\begin{tabular}{|c|c|c|c|}
\hline Outcome & Performance & Challenges \& Lessons & Way forward \\
\hline $\begin{array}{l}\text { - Increased number of orphans } \\
\text { and most vulnerable children } \\
\text { reached with effective social } \\
\text { protection }\end{array}$ & $\begin{array}{l}\text { - Survey has been conducted in } 4 \\
\text { regions: Arusha, Kilimanjaro, } \\
\text { Manyara, and Mbeya. And six } \\
\text { FDCs. 13,424 Orphans and Most } \\
\text { Vulnerable Children were } \\
\text { identified; among them } 40 \text { children } \\
\text { are assisted in education. } \\
\text { - Development of the National Social } \\
\text { Protection Framework (NSPF). } \\
\text { - A total number of } 225 \text { dispensaries } \\
\text { have been constructed in rural } \\
\text { areas. }\end{array}$ & & $\begin{array}{l}\text { - Conduct survey in the } \\
\text { whole country on } \\
\text { OMVC to find } \\
\text { solutions } \\
\text { - To disseminate } \\
\text { knowledge for } \\
\text { conducting surveys to } \\
\text { District Community } \\
\text { Development so that } \\
\text { they can incorporate it } \\
\text { in their routine work. } \\
\text { Finalize and start } \\
\text { implementing the } \\
\text { Multi sectoral Social } \\
\text { Protection Framework }\end{array}$ \\
\hline $\begin{array}{l}\text { - Reduce violence against } \\
\text { women }\end{array}$ & $\begin{array}{l}\text { - Crime rate reduced by } 24 \text { percent } \\
\text { Road accident has increased from } \\
17,220 \text { to } 18,187 \text { in year } 2005 \text { and } \\
2006 \text { respectively an increase of } 5.6 \\
\text { percent. }\end{array}$ & $\begin{array}{l}\text { - Impact of globalization and increase of } \\
\text { technologies, shortage of police force staff } \\
\text { against increase of population, lack of know- } \\
\text { how. }\end{array}$ & \\
\hline $\begin{array}{l}\text { - Implementing } \text { HIV/AIDS } \\
\text { interventions programme in } \\
\text { work places }\end{array}$ & $\begin{array}{l}\text { - Training Institutions, MDAs, LGAs } \\
\text { and NSAs sensitized on HIV/AIDS; } \\
\text { seminars for Peer Educators }\end{array}$ & $\begin{array}{l}\text { - AIDS cases still a problem. } \\
\text { - New measures should be applied to avoid new } \\
\text { HIV/AIDS cases. }\end{array}$ & \\
\hline
\end{tabular}




\begin{tabular}{|c|c|c|c|}
\hline Outcome & Performance & Challenges \& Lessons & Way forward \\
\hline & $\begin{array}{l}\text { - } 40 \text { students trained on peer } \\
\text { education as of June } 2007 \\
\text { - Monitoring and Evaluation of } \\
\text { HIV/AIDS activities in MDAs, } \\
\text { LGAs and NSAs. } \\
\text { - } 30 \text { district hospitals have been } \\
\text { distributed with CD4 scanning } \\
\text { machines with affiliated } \\
\text { accessories. }\end{array}$ & & \\
\hline $\begin{array}{l}\text { - Effective HIV/AIDS education, } \\
\text { environment and life skills } \\
\text { programmes offered in all } \\
\text { primary schools and teachers' } \\
\text { college }\end{array}$ & $\begin{array}{l}\text { - Ministry of education and } \\
\text { vocational training mandated to } \\
\text { mainstream HIV/AIDs activities } \\
\text { under its core mandate } \\
\text { - Progress made in School Based } \\
\text { Prevention for Primary and } \\
\text { Secondary Level } \\
\text { - Trained teachers in Life Skills based } \\
\text { HIV/AIDS issues and Peer } \\
\text { Education. } \\
\text { Promoted the use of the media and }\end{array}$ & $\begin{array}{l}\text { - Inadequate of trained primary teachers on the } \\
\text { areas of environment and HIV/AIDS. } \\
\text { - MOEVT has a pivotal role in preventing new } \\
\text { infection } \\
\text { - Peer Education Programmes are effective tool } \\
\text { for influencing positive behavior change in } \\
\text { different age groups. } \\
\text { - Knowledge/training on HIV/AIDS in primary } \\
\text { and secondary level - builds up a strong } \\
\text { foundation for HIV/AIDS prevention. To be } \\
\text { provided countrywide }\end{array}$ & \\
\hline
\end{tabular}




\begin{tabular}{|l|l|l|}
\hline Outcome & Performance & Challenges \& Lessons \\
\hline & drama in the development of school- \\
based interventions. & \\
Facilitated open discussions on \\
HIV/AIDS in schools \\
HIV/AIDS and reproductive health \\
incorporated into primary and \\
secondary school curricula. \\
HIV/AIDS is now taught. \\
Teachers trained in Life Skills about \\
480 schools have conducted training \\
in HIV/AIDS-based Life Skills and \\
Sex Education under the District \\
Response Initiative (DRI). There are \\
currently about 132 schools with \\
teachers trained in HIV/AIDS-based \\
Life Skills education \\
Peer education: so far 175 schools \\
have trained peer educators.
\end{tabular}


Goal 2: Improved Survival, health and well-being of all children and women and of specially vulnerable groups

\begin{tabular}{|c|c|c|c|}
\hline Outcome & Performance & Challenges \& Lessons learnt & Way forward \\
\hline $\begin{array}{l}\text { - Reduced infant mortality from } \\
95 \text { in } 2002 \text { to } 50 \text { in } 2010 \text { per } \\
1,000 \text { live births }\end{array}$ & $\begin{array}{l}\text { - The Infant Mortality rate has } \\
\text { decreased from } 115 / 1000 \text { live births } \\
\text { to } 68 / 1000 \text { in year } 1990 \text { s and } 2006 \\
\text { respectively. }\end{array}$ & $\begin{array}{l}\text { - Rolling up of IMCI, early diagnosis and } \\
\text { treatment of malaria within } 24 \mathrm{hrs} \text { at least } \\
60 \text { percent of the infected children. } \\
\text { - Availability and accessibility to quality }\end{array}$ & \begin{tabular}{|lr} 
Scale up & proven \\
interventions like & IMCI, \\
correct & Malaria \\
Management, & ITNS,
\end{tabular} \\
\hline $\begin{array}{l}\text { - Reduced child (under five) } \\
\text { mortality from } 154 \text { to } 79 \text { per } \\
1,000 \text { live births }\end{array}$ & $\begin{array}{l}\text { - Under } 5 \text { MR has decreased from } \\
191 / 1000 \text { to } 133 / 1000 \text { in year } 1990 \text { s } \\
\text { to } 2006 \text { respectively. }\end{array}$ & $\begin{array}{l}\text { health care, with health services provided } \\
\text { by trained staff. } \\
\text { - Infrastructure and supplies constraints to } \\
\text { new anti-malaria regime and cost } \\
\text { constraints in the provision of care. } \\
\text { MDG } 4 \text { is within reach by } 2015 \text {, if } \\
\text { services are made available. Mortalities in } \\
\text { children are due to underlying malnutrition } \\
\text { (MDG 1), lack of education, specifically } \\
\text { female education MDG } 2 \text {. }\end{array}$ & 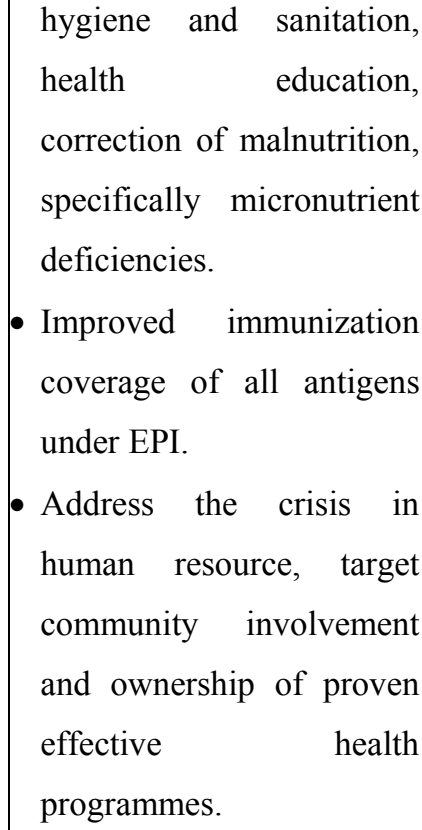 \\
\hline
\end{tabular}




\begin{tabular}{|c|c|c|c|}
\hline Outcome & Performance & Challenges \& Lessons learnt & Way forward \\
\hline $\begin{array}{l}\text { - Reduced prevalence of wasting } \\
\text { in under fives from } 5.4 \text { percent } \\
\text { to } 2 \text { percent in } 2010\end{array}$ & $\begin{array}{l}\text { - Slight improvement of reduction of } \\
\text { malnutrition; drop in stunting from } \\
43.8 \text { percent to } 38 \text { percent, wasting } \\
\text { from } 5 \text { percent to } 3 \text { percent ( } 2004 \\
\text { data). For rural areas the rates } \\
\text { declined from } 48 \text { percent to } 41 \\
\text { percent; rose in urban areas to } 26 \\
\text { percent. }\end{array}$ & $\begin{array}{l}\text { - It is unlikely the target of } 20 \text { percent in } \\
2010 \text { will be reached. The droughts } \\
\text { followed by hunger in } 2004 / 05 \text { and } 2006 \\
\text { paint a gloomy picture. } \\
\text { - Causes of malnutrition are multi-factorial: } \\
\text { multi-pronged, long-term strategies needed } \\
\text { Address regional and district variations. }\end{array}$ & $\begin{array}{l}\text { - Improved childhood } \\
\text { feeding by educating } \\
\text { mothers (IEC) and } \\
\text { nutritional programmes } \\
\text { - Correct management of } \\
\text { childhood illnesses. }\end{array}$ \\
\hline $\begin{array}{l}\text { - Increased coverage of births } \\
\text { attended by trained personnel } \\
\text { from } 50 \text { percent to } 80 \text { percent } \\
\text { in } 2010\end{array}$ & $\begin{array}{l}\text { - As per TDHS 2005; } 46 \text { percent of } \\
\text { births had been attended by medical } \\
\text { officer/assistant, } 4 \text { percent by medical } \\
\text { officers, } 2.2 \text { percent by clinical } \\
\text { officers/assistant, and } 37.1 \text { percent by } \\
\text { nurse or midwife. } \\
\text { - } 47 \text { percent of births have been taken } \\
\text { place in health centers. }\end{array}$ & & \\
\hline $\begin{array}{l}\text { - Health boards and facility } \\
\text { committees in place and } \\
\text { operational in all districts }\end{array}$ & $\begin{array}{l}\text { - Health boards established in all } 127 \\
\text { LGAs. Boards and Committees are in } \\
\text { place. } \\
\text { - Service delivery agreements } \\
\text { decentralized to LGAs as a function }\end{array}$ & $\begin{array}{l}\text { - Capacity of the LGAs is still low oversee } \\
\text { function of the Health Boards and } \\
\text { Committee. } \\
\text { - The concept of service agreements is new } \\
\text { at the LGA levels. } \\
\text { - Boards and committees need to empower }\end{array}$ & $\begin{array}{l}\text { - Continued advocacy for } \\
\text { health reforms. } \\
\text { - TA to the LGAs in } \\
\text { training the "HSBs and } \\
\text { Committees. } \\
\text { - Strengthen PPP and }\end{array}$ \\
\hline
\end{tabular}




\begin{tabular}{|c|c|c|c|}
\hline Outcome & Performance & Challenges \& Lessons learnt & Way forward \\
\hline & $\begin{array}{l}\text { of the Health Service Boards. PPP - } \\
\text { Committee in place to oversee this } \\
\text { function. }\end{array}$ & $\begin{array}{l}\text { communities for decentralization. } \\
\text { - Some LGAs have weak HSBs and } \\
\text { committees. } \\
\text { - Boards and committees need to be } \\
\text { democratic } \\
\text { - Institutionalize advocacy and re-training } \\
\text { - Some LGAs are resisting service } \\
\text { agreements } \\
\text { - Other reforms affect Health sector reforms } \\
\text { and performance and harmonization of } \\
\text { reforms } \\
\text { - Advocacy is needed at all levels. }\end{array}$ & $\begin{array}{l}\text { community empowerment } \\
\text { - Negotiate actively at } \\
\text { government level to settle } \\
\text { RS - composition and } \\
\text { place of RHMTS. } \\
\text { - Accelerate Regional } \\
\text { Hospital reforms. } \\
\text { Continuous and enhanced } \\
\text { advocacy of Team } \\
\text { operations. }\end{array}$ \\
\hline $\begin{array}{l}\text { Reduced maternal mortality } \\
\text { from } 529 \text { to } 265 \text { in } 2010 \text { per } \\
100,000\end{array}$ & $\begin{array}{l}\text { - The maternal mortality has increased } \\
\text { from } 529 / 1000 \text { live births to } 578 / 1000 \\
\text { in year } 2000 \text { and } 2005 \text { respectively. }\end{array}$ & $\begin{array}{l}\text { - HIV and AIDS has retarded efforts to } \\
\text { reduce maternal mortality. } \\
\text { - Focus more on rural areas for effective } \\
\text { service provision. } \\
\text { - Emergency obstetrics care is important in } \\
\text { reversing the trends. }\end{array}$ & $\begin{array}{l}\text { - Invest operationalization } \\
\text { of EMOC. } \\
\text { - Make maternal services } \\
\text { available and user } \\
\text { friendly. } \\
\text { - Quality Improvement. } \\
\text { - Resolve the HRH crisis }\end{array}$ \\
\hline $\begin{array}{l}\text { - Reduced HIV prevalence } \\
\text { among } 15-24 \text { year pregnant }\end{array}$ & $\begin{array}{l}\text { - HIV/AIDS prevalence rates for } 15- \\
24 \text { years is estimated } 7 \text { percent (THIS }\end{array}$ & $\begin{array}{l}\text { - More efforts are needed to reverse the } \\
\text { trend }\end{array}$ & $\begin{array}{lr}\text { - Operationalize } & \text { the } \\
\text { National } & \text { HIV/AIDS }\end{array}$ \\
\hline
\end{tabular}




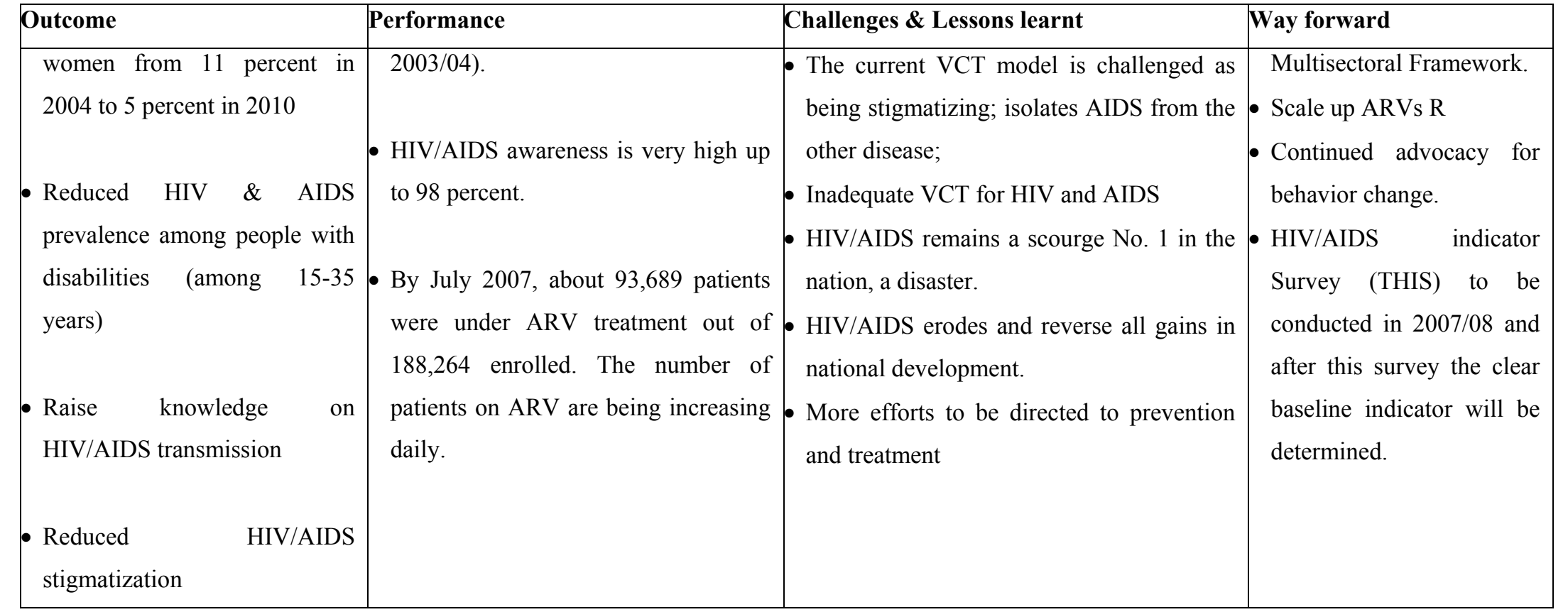

Goal 3: Access to clean, affordable and safe water, sanitation, decent shelter and a safe and sustainable environment and thereby, reduced vulnerability from environmental risk.

\begin{tabular}{|l|l|l|l|}
\hline Outcome & Performance & Challenges \& Lessons learnt & Way forward \\
\hline
\end{tabular}




\begin{tabular}{|c|c|c|c|}
\hline Outcome & Performance & Challenges \& Lessons learnt & Way forward \\
\hline $\begin{array}{l}\text { - Increased proportion of rural } \\
\text { population with access to clean } \\
\text { and safe water from } 53 \text { percent } \\
\text { in } 2003 \text { to } 65 \text { percent in } \\
2009 / 2010 \text { within } 30 \text { minutes } \\
\text { of time spent on collection of } \\
\text { water }\end{array}$ & $\begin{array}{l}\text { - Population with access to clean and } \\
\text { safe water in rural areas has increased } \\
\text { from } 53.5 \text { percent to } 55.7 \text { percent in } \\
\text { year } 2005 / 06 \text { and } 2006 / 07 \\
\text { respectively, while in urban the } \\
\text { increase was from } 73 \text { percent to } 78 \\
\text { percent (same years). } \\
653 \text { water well drilled in rural areas }\end{array}$ & $\begin{array}{l}\text { - LGAs limited staff hindering } \\
\text { accomplishment of water projects on time } \\
\text { - Existence of drought in the country } \\
\text { causing the water bodies loss water } \\
\text { - Inadequate skills to LGAs staff to manage } \\
\text { water resources and facilities } \\
\text { - Employ qualified staff (professional staff) } \\
\text { - The need for LGAs to training their staff }\end{array}$ & $\begin{array}{l}\text { - Enhance training of staff } \\
\text { and seminar provision } \\
\text { - Employ adequate and } \\
\text { professional staff at } \\
\text { Ministerial and LGAs level } \\
\text { - Introducing more Water } \\
\text { Supply projects in both } \\
\text { rural and urban areas. }\end{array}$ \\
\hline $\begin{array}{l}\text { - Increased urban population } \\
\text { with access to clean and safe } \\
\text { water from } 73 \text { percent in } 2003 \\
\text { to } 90 \text { percent by } 2009 / 10\end{array}$ & $\begin{array}{l}\text { - The population with access to clean } \\
\text { and safe water has increased from74 } \\
\text { percent to } 78 \text { percent in year } 2005 / 06 \\
\text { and } 2006 / 07 \text { in urban areas } \\
\text { - } 82 \text { percent of water users have their } \\
\text { water line installed with water-meter } \\
\text { - Tshs } 101 \text { billion collected from water } \\
\text { users as service charges }\end{array}$ & $\begin{array}{l}\text { - Drought caused water problem almost all } \\
\text { over dry regions } \\
\text { - Environmental degradation } \\
\text { - Small rate of investment in water } \\
\text { harvesting and supply } \\
\text { - The need to find alternative sources of } \\
\text { water and environmental conservation }\end{array}$ & $\begin{array}{l}\text { - Enhance rain water } \\
\text { harvesting advocacy to } \\
\text { water users as well } \\
\text { environmental practice and } \\
\text { investing more on large } \\
\text { water sources to ensure } \\
\text { sustainable water supply. }\end{array}$ \\
\hline $\begin{array}{l}\text { - Increased access to improved } \\
\text { sewerage facilities from } 17 \\
\text { percent in } 2003 \text { to } 30 \text { percent }\end{array}$ & $\begin{array}{l}\text { - } 17 \text { percent access to sewerage service } \\
\text { in different Urban Water Authorities } \\
\text { was maintained. }\end{array}$ & $\begin{array}{l}\text { - Limited resources in terms of human } \\
\text { resources and fund to accomplish the } \\
\text { planned activities }\end{array}$ & $\begin{array}{l}\text { - Enhance rehabilitation, } \\
\text { expansion and construction } \\
\text { of new sewerage facility }\end{array}$ \\
\hline
\end{tabular}




\begin{tabular}{|c|c|c|c|}
\hline Outcome & Performance & Challenges \& Lessons learnt & Way forward \\
\hline $\begin{array}{l}\text { in } 2010 \text { in respective urban } \\
\text { areas. }\end{array}$ & $\begin{array}{l}\text { - } 25 \text { percent of the wastewater } \\
\text { generated daily was collected and } \\
\text { disposed through sewerage systems. }\end{array}$ & $\begin{array}{l}\text { - Old sewerage facilities for rehabilitation, } \\
\text { expansion; construction of new lines. } \\
\text { - The need to increase rehabilitation, } \\
\text { expansion and construction of new } \\
\text { sewerage facilities } \\
\text { - The need to include Municipals with no } \\
\text { sewerage facilities in the plan }\end{array}$ & lines. \\
\hline $\begin{array}{l}\text { - } 95 \text { percent of people with } \\
\text { access to basic sanitation by } \\
2010\end{array}$ & $\begin{array}{l}\text { - } 24 \text { Districts had a "head start" having } \\
\text { begun implementation of the Rural } \\
\text { Water Supply and Sanitation Projects } \\
\text { (RWSSP) }\end{array}$ & $\begin{array}{l}\text { - Most of the LGAs have weak staff in } \\
\text { terms of skills } \\
\text { - Shortage of fund to implement the RWSSP } \\
\text { - Poor attitude by Rural residents on use of } \\
\text { latrines } \\
\text { - All districts to be in the Rural Water } \\
\text { Supply and Sanitation Projects } \\
\text { - LGAs to effectively implement RWSSP. }\end{array}$ & $\begin{array}{l}\text { - Enhance implementation } \\
\text { of RWSSP in all districts } \\
\text { during 2006/2007 } \\
\text { - More employees in LGAs } \\
\text { Enhance sanitation, } \\
\text { upgrade latrine, hygiene } \\
\text { and Water Supply } \\
\text { Programme in rural areas }\end{array}$ \\
\hline $\begin{array}{l}\text { - Reduced water related } \\
\text { environmental pollution levels } \\
\text { from } 20 \text { percent in } 2003 \text { to } 10 \\
\text { percent in } 2010 .\end{array}$ & $\begin{array}{l}\text { - } 493 \text { water resource points have been } \\
\text { inspected to examine water pollutants } \\
\text { and environmental degradation } \\
\text { agents. }\end{array}$ & $\begin{array}{l}\text { - Promote sanitation in rural areas. } \\
\text { Faster environmental degradation and } \\
\text { pollutants disposal resulting from daily } \\
\text { human activities } \\
\text { - Observe environmental conservation } \\
\text { practice national wide }\end{array}$ & $\begin{array}{l}\text { - Enhance environmental } \\
\text { conservation in a } \\
\text { participatory approach } \\
\text { national wide. }\end{array}$ \\
\hline
\end{tabular}




\begin{tabular}{|c|c|c|c|}
\hline Outcome & Performance & Challenges \& Lessons learnt & Way forward \\
\hline $\begin{array}{l}\text { - Planned and serviced urban } \\
\text { settlements with functioning } \\
\text { town planning procedures in } \\
\text { place }\end{array}$ & $\begin{array}{l}\text { - } 40 \text { samples of building designs types } \\
\text { produced for Mwanza city, Tabora } \\
\text { and Mbeya Municipalities } \\
\text { - } 18 \text { interim Land Use Plans of urban } \\
\text { settlements were prepared to arrest the } \\
\text { haphazardly growing urban areas }\end{array}$ & $\begin{array}{l}\text { - To produce as many samples to cater for } \\
\text { demands of several lands developers so as } \\
\text { to reduce bureaucracy in issuing of } \\
\text { building permits } \\
\text { Need to use those samples to ease } \\
\text { acquisition of building permit }\end{array}$ & $\begin{array}{l}\text { - To use those samples to } \\
\text { shorten procedures needed } \\
\text { to get building permit. } \\
\text { - Prepare more plans for } \\
\text { haphazardly growing } \\
\text { urban areas }\end{array}$ \\
\hline $\begin{array}{l}\text { - Increased number of people } \\
\text { having secured tenure of land } \\
\text { and properties that can be } \\
\text { mortgaged and women } / \text { men } \\
\text { have equal rights to access, } \\
\text { ownership and inheritance. }\end{array}$ & $\begin{array}{l}\text { - 4,585 Letters of Offer and 9,107 } \\
\text { Certificates of Title prepared } \\
\text { - 9,107 Certificates of Title and 9,491 } \\
\text { documents registered } \\
\text { - } 2,496 \text { valuations prepared and } \\
\text { approved } \\
\text { - } 102 \text { and } 538 \text { properties granted } \\
\text { approval for Mortgage and Transfer } \\
\text { respectively } \\
\text { - } 200,000 \text { properties in unplanned } \\
\text { settlements identified and } 30,000 \\
\text { residential licenses issued. } \\
\text { - Sensitization and awareness on land } \\
\text { laws } \\
\text { - Dissemination of research findings on } \\
\text { low-cost housing; three demonstrative } \\
\text { low-cost housing constructed }\end{array}$ & $\begin{array}{l}\text { - Most land parcels/Plots are not surveyed, } \\
\text { Double allocation, forged document. } \\
\text { - Need to allocate sufficient funds for } \\
\text { acquisition of land for plot production. }\end{array}$ & $\begin{array}{l}\text { - Survey and identify more } \\
\text { properties to allow } \\
\text { issuance of certificate of } \\
\text { titles and residential } \\
\text { licenses } \\
\text { - Plot verification at Tegeta, } \\
\text { Mbezi \& Boko and } \\
\text { issuance of watermarked } \\
\text { certificates of occupancy. }\end{array}$ \\
\hline
\end{tabular}




\begin{tabular}{|l|l|l|l|}
\hline Outcome & Performance & Challenges \& Lessons learnt & Way forward \\
\hline & $\begin{array}{l}211 \text { village land certificates and 3,940 } \\
\text { certificates of customary rights of } \\
\text { occupancy issued. }\end{array}$ & & \\
\hline
\end{tabular}

\section{Goal 4: Adequate Social Protection and Rights of the Vulnerable and needy Groups with Basic needs and Services}

\begin{tabular}{|c|c|c|c|}
\hline Outcome & Performance & Challenges \& Lessons learnt & Way forward \\
\hline $\begin{array}{l}\text { - Increased number of orphans } \\
\text { and most vulnerable children } \\
\text { reached with effective social } \\
\text { protection measures by } 2010\end{array}$ & $\begin{array}{l}\text { - National OVC/MVCs identification } \\
\text { programme implemented in } 24 \\
\text { districts } \\
\text { - National Social Security Policy } \\
\text { developed }\end{array}$ & $\begin{array}{ll}\text { - } & \text { High level of poverty } \\
\text { - } & \text { Increase of HIV/AIDS deaths } \\
\text { - } & \text { Increase of family problems } \\
\text { - } & \text { Expand economic development } \\
\text { - } & \text { High level of poverty } \\
\text { - } & \text { Expand economic development }\end{array}$ & $\begin{array}{l}\text { Identification } \\
\text { OVC/MVCs }\end{array}$ \\
\hline $\begin{array}{l}20 \text { percent of children and } \\
\text { adults with disabilities reached } \\
\text { with effective social protection } \\
\text { measures by } 2010\end{array}$ & - National Disability Policy developed. & $\begin{array}{l}\text { - } \quad \text { High level of poverty } \\
\text { - } \quad \text { Expand economic development } \\
\text { - } \quad \text { High level of poverty }\end{array}$ & $\begin{array}{l}\text { - Finalize and implement the } \\
\text { National Disability } \\
\text { Implementation Strategy }\end{array}$ \\
\hline
\end{tabular}




\begin{tabular}{|c|c|c|c|}
\hline Outcome & Performance & Challenges \& Lessons learnt & Way forward \\
\hline $\begin{array}{l}-40 \text { percent of eligible older } \\
\text { people reached with effective } \\
\text { social protection measures by } \\
2010\end{array}$ & - National Ageing Policy developed. & 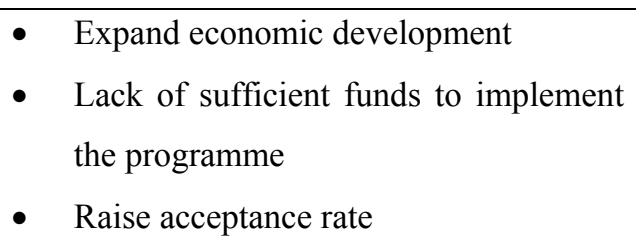 & $\begin{array}{lr}\text { Finalize and implement } \\
\text { National } & \text { Ageing } \\
\text { Implementation Strategy }\end{array}$ \\
\hline $\begin{array}{l}\text { - Support to vulnerable groups } \\
\text { - Increased capacity of poor } \\
\text { households to care for } \\
\text { vulnerable groups targeting } \\
\text { older people, orphans, other } \\
\text { vulnerable children and } \\
\text { PLWHAs. }\end{array}$ & $\begin{array}{l}\text { - National OVC/MVCs identification } \\
\text { programme implemented in } 24 \\
\text { districts } \\
\text { - National Social Security Policy } \\
\text { developed } \\
\text { - National Disability Policy developed } \\
\text { - National Ageing Policy developed } \\
\text { - Guidelines for accessing free health } \\
\text { treatment for vulnerable groups have } \\
\text { been developed. }\end{array}$ & $\begin{array}{l}\text { - High unemployment } \\
\text { - Increase inspections in the workplace }\end{array}$ & $\begin{array}{l}\text { - Identification } \\
\text { OVC/MVCs } \\
\text { - Finalize the National } \\
\text { Disability Implementation } \\
\text { Strategy } \\
\text { - Finalize the National } \\
\text { Ageing Implementation } \\
\text { Strategy }\end{array}$ \\
\hline $\begin{array}{l}\text { Child Protection \& Rights } \\
\text { Reduce proportion of children } \\
\text { in Labour from } 25 \text { percent to } \\
\text { less than } 10 \text { percent by year } \\
2010 \text { and avail to them } \\
\text { alternatives, enrolment in } \\
\text { primary education, COBET and } \\
\text { vocational education skills } \\
\text { training }\end{array}$ & $\begin{array}{l}\text { - National Programme against Child } \\
\text { Labour (Time bound Programme) } \\
\text { implemented in 14 Districts }\end{array}$ & & $\begin{array}{l}\text { - Implement time bound } \\
\text { programme } \\
\text { - Continue implementing } \\
\text { demand-driven skills. }\end{array}$ \\
\hline
\end{tabular}


Goal 5: Systems in place to ensure effective universal access to quality public services that are affordable and available

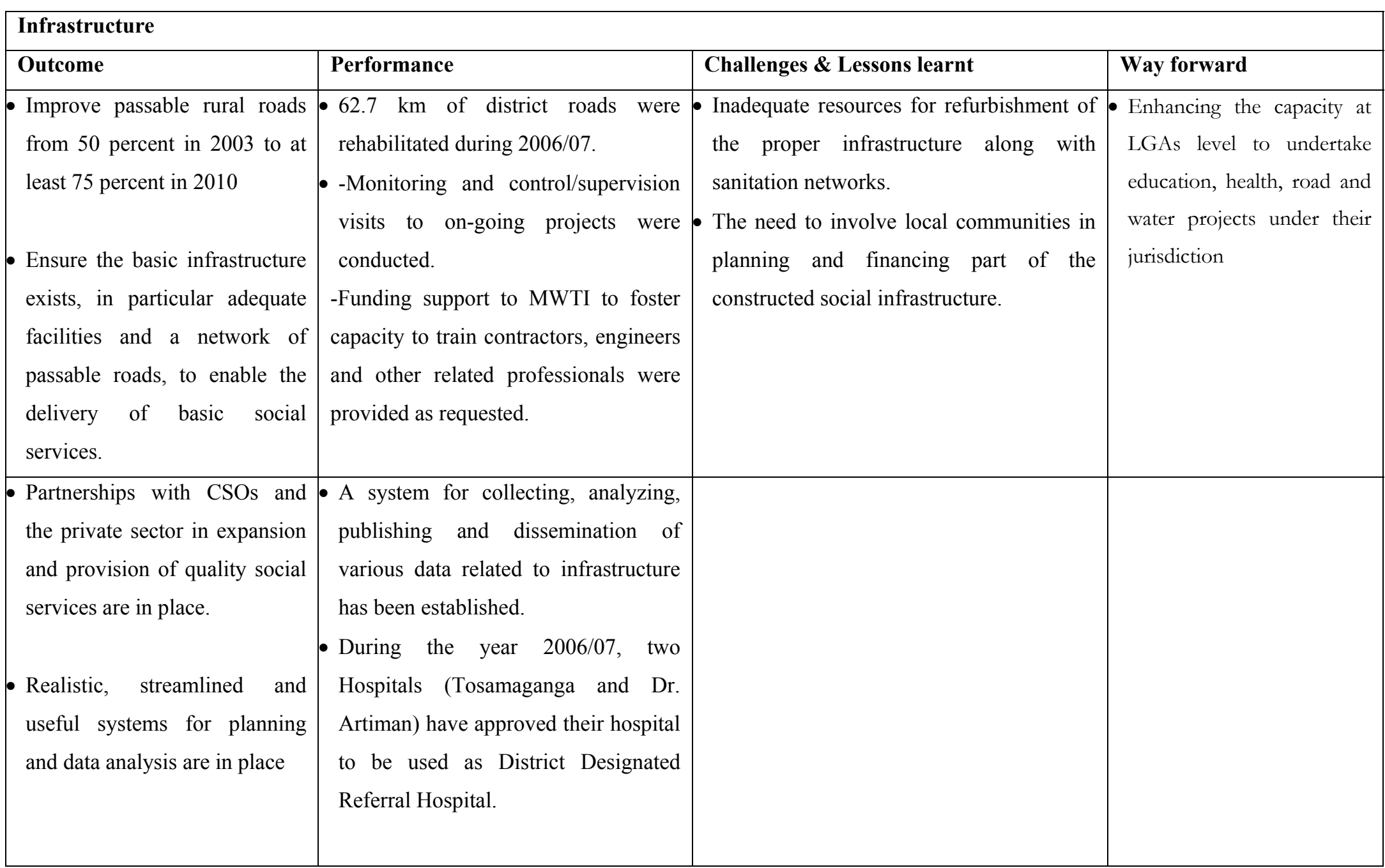


CLUSTER III: GOVERNANCE AND ACCOUNTABILITY

Goal 1: Structures and Systems of governance as well as the rule of law are democratic, participatory, representative, accountable and inclusive

\begin{tabular}{|c|c|c|c|}
\hline Outcome & Performance & Challenges \& Lessons learnt & Way forward \\
\hline $\begin{array}{l}\text { Ensure representative, } \\
\text { inclusive (poor and vulnerable } \\
\text { groups) and accountable } \\
\text { governance institutions } \\
\text { operating at all levels. }\end{array}$ & $\begin{array}{l}\text { The number of birth and death } \\
\text { registered has significantly increased } \\
\text { and currently has reached } 829,384 \\
\text { and } 118,538 \text { respectively. } \\
\text { - } 31.1 \text { percent of villages/mtaa have and } \\
\text { use birth registers } \\
\text { - Percentage of women I decision } \\
\text { making position at central } \\
\text { government, local government t and } \\
\text { regional secretariat rose to } 22.02 \\
\text { percent, } 38.36 \text { percent and } 25.44 \\
\text { percent respectively. } \\
\text { - Proportion of women representatives } \\
\text { in the parliament has currently } \\
\text { reached } 30.4 \text { percent. } \\
\text { hold quarterly meetings with public }\end{array}$ & $\begin{array}{l}\text { Available data on CCROs is not } \\
\text { disaggregated thereby making it difficult } \\
\text { to assess ownership by gender at the } \\
\text { household level. } \\
\text { - Inadequate analysis cum consumption of } \\
\text { the information by the community at the } \\
\text { grass root level } \\
\text { public information that is provided by } \\
\text { LGAs at the grass root level } \\
\text { A A need to disaggregate the available } \\
\text { information } \\
\text { A study to establish baseline information } \\
\text { on total number of people owning CCROs } \\
\text { at household level and by gender }\end{array}$ & $\begin{array}{l}\text { To continue to scaling up } \\
\text { public awareness with } \\
\text { respects to the role and } \\
\text { usefulness of public } \\
\text { information. }\end{array}$ \\
\hline
\end{tabular}




\begin{tabular}{|c|c|c|c|}
\hline \multirow[t]{2}{*}{ Outcome } & Performance & Challenges \& Lessons learnt & Way forward \\
\hline & $\begin{array}{l}\text { minutes. } \\
\text { - Over 95percent held annual meetings } \\
100 \text { percent of Local Government } \\
\text { Authorities complied with posting } \\
\text { information of budgets, revenues and } \\
\text { actual expenditures on the public } \\
\text { notice boards for public use. } \\
\text { - 4,585 Letters of Offer and 9,107 } \\
\text { Certificates of Title prepared } \\
\text { 9,107 Certificates of Title and } \\
9,491 \text { other documents registered } \\
\text { - 200,000 properties in unplanned } \\
\text { settlements identified and } 30,000 \\
\text { residential licenses issued. } \\
\text { 211 village land certificates and 3,940 } \\
\text { Certificates of Customary Rights of } \\
\text { Occupancy issued. }\end{array}$ & & \\
\hline
\end{tabular}

Goal 2: Equitable allocation of public resources with corruption effectively addressed 


\begin{tabular}{|c|c|c|c|}
\hline Outcome & Performance & Challenges \& Lessons learnt & Way forward \\
\hline $\begin{array}{l}\text { Public resources are allocated, } \\
\text { accessible and used in an } \\
\text { equitable, accountable and } \\
\text { transparent manner } \\
\text { Institute effective regulations } \\
\text { and mechanisms regarding } \\
\text { petty and grand corruption. }\end{array}$ & $\begin{array}{l}\text { - The government has also } \\
\text { strengthened compliance with Public } \\
\text { Procurement Act, as a result more } \\
\text { MDA's and LGA's complied with the } \\
\text { Act. } \\
\text { - According to PPRA report (PAF), } 20 \\
\text { procuring entities out of } 339 \text { have } \\
\text { been audited and had an average level } \\
\text { of compliance of } 39 \text { percent. } \\
\text { - Clean certificates to MDAs } \\
24 \text { percent in } 2005 \\
57 \text { percent in } 2006 \\
\text { - Clean certificates to LGAs } \\
9 \text { percent in } 2005 \\
53 \text { percent in } 2006 \\
\text { - All councils comply fully (100 } \\
\text { percent) in posting information }\end{array}$ & $\begin{array}{l}\text { - Management of public institution need to } \\
\text { pay attention to PMU. } \\
\text { - Auditing activities of the public } \\
\text { institutions need to be strengthened to } \\
\text { reduce divergence of resources in public } \\
\text { institutions. } \\
\text { - Strengthen capacity and pay attention to }\end{array}$ & $\begin{array}{l}\text { - Continue with } \\
\text { strengthening of the } \\
\text { National Audit Office so } \\
\text { that more public } \\
\text { institutions are regularly } \\
\text { audited. } \\
\text { - Continue to strengthen } \\
\text { awareness raising } \\
\text { activities. } \\
\text { More training on ethics and } \\
\text { integrity in } \\
\text { professionalism. }\end{array}$ \\
\hline
\end{tabular}




\begin{tabular}{|l|l|l|l|}
\hline Outcome & Performance & Way forward \\
\hline & corruption case files reported 15 cases & & \\
& qualified for court hearing. & & \\
& In 2005, the number of corruption & & \\
cases convicted was 3.5percent of & & \\
investigated cases sanctioned for & & & \\
& prosecution by the Director of Public & & \\
& Prosecutions. & & \\
\hline
\end{tabular}

Goal 3: Effective Public Service framework in place to provide foundation for service delivery improvements and poverty reduction

\begin{tabular}{|c|c|c|c|}
\hline Outcome & Performance & Challenges \& Lessons learnt & Way forward \\
\hline $\begin{array}{l}\text { Administrative systems of } \\
\text { public institutions are managed } \\
\text { transparently and in the best } \\
\text { interest of people they serve. } \\
\text { - Decentralization by devolution } \\
\text { institutionalized and } \\
\text { implemented to enhance public } \\
\text { ownership of development and } \\
\text { poverty reduction process }\end{array}$ & $\begin{array}{l}\text { - Adaptation and Implementation of the } \\
\text { principles of decentralization by } \\
\text { devolution and currently resource } \\
\text { envelop has increased to } 19.7 \text { percent } \\
\text { in } 2006 / 07 \text { to LGAs. } \\
\text { - Increased pay levels for public } \\
\text { servants to } 107 \text { percent of the } \\
\text { Medium Pay Targets. The baseline of } \\
86 \text { percent in } 2005 \text { (PAF). }\end{array}$ & $\begin{array}{l}\text { - Understanding of decentralization by } \\
\text { devolution concept and process needs to } \\
\text { be raised among the central and local } \\
\text { government authorities. } \\
\text { A need to harmonize the process of } \\
\text { decentralization by devolution in the } \\
\text { constitution in order to ensure consistency } \\
\text { and continuity. }\end{array}$ & $\begin{array}{l}\text { - Continue with sensitization } \\
\text { and awareness raising } \\
\text { among MDAs to ensure } \\
\text { that there is smooth } \\
\text { implementation of } \\
\text { decentralization by } \\
\text { devolution policy. }\end{array}$ \\
\hline
\end{tabular}


Goals 4: Rights of the poor and vulnerable groups are protected and promoted in the justice systems

\begin{tabular}{|c|c|c|c|}
\hline Outcome & Performance & Challenges \& Lessons learnt & Way forward \\
\hline $\begin{array}{l}\text { - Percentage of court cases } \\
\text { outstanding declined } \\
\text { - Reduction of prisoners in } \\
\text { remand for two or more years. }\end{array}$ & $\begin{array}{l}\text { - Improve the capacity of judicial } \\
\text { system whereby appointment of } 23 \\
\text { judges, } 77 \text { residents' magistrates, } 46 \\
\text { primary courts magistrates and } 211 \\
\text { attorneys have been made in } 2006 / 07 \text {. } \\
\text { - Accomplishment of LSRP Phase I } \\
\text { civilianization of prosecution services } \\
\text { in } 6 \text { regions. } \\
\text { - percent of outstanding cases for more } \\
\text { than a year } \\
\text { 58percent in } 2005 \\
46.7 \text { percent in } 2006\end{array}$ & $\begin{array}{l}\text { - There is shortage of staff and other } \\
\text { facilities in courtroom } \\
\text { - Delays in instituting information system to } \\
\text { link various legal departments }\end{array}$ & $\begin{array}{l}\text { To enable the legal sector } \\
\text { to deal with demands from } \\
\text { various groups, especially } \\
\text { those with special need, in } \\
\text { the society }\end{array}$ \\
\hline
\end{tabular}

\section{Goal 5: Reduction of political and social exclusion and intolerance}

\begin{tabular}{|l|l|l|}
\hline Outcome & Performance & Challenges \& Lessons learnt \\
\hline - Develop political and social & - Number of cases filed on the & - Skills development and enhancement in \\
systems and institutions which & infringement of human rights & Human Rights understanding and frequent \\
of the Commission for
\end{tabular}




\begin{tabular}{|c|c|c|c|}
\hline Outcome & Performance & Challenges \& Lessons learnt & Way forward \\
\hline $\begin{array}{l}\text { allow for full participation of } \\
\text { all citizens including the poor } \\
\text { and vulnerable groups. } \\
\text { Ensure institutions and agents } \\
\text { of government such as the } \\
\text { police, courts and prisons } \\
\text { observe human rights and } \\
\text { ensure justice and security of } \\
\text { all citizens }\end{array}$ & $\begin{array}{l}\text { In 2004/05 } 2789 \\
\text { In 2005/06 } 3812 \\
\text { - A total of 4,523 new complaints on } \\
\text { human rights violations were received } \\
\text { in 2006/07 and 3,149 complaints were } \\
\text { resolved. } \\
\text { - The Commission of Human Rights } \\
\text { and Good Governance received } 226 \\
\text { complaints for human rights } \\
\text { violations from remandees, out of } \\
\text { these } 39 \text { were advised and } 187 \text { were } \\
\text { resolved. } \\
\text { - Establishment of } 2 \text { new regional } \\
\text { offices for the commission of human } \\
\text { rights at Lindi and Mwanza region. } \\
\text { - Commission for Human Rights } \\
\text { managed visited and inspect a total } \\
\text { number of } 35 \text { prisons and } 53 \text { police } \\
\text { stations in } 33 \text { districts in } 2006 / 07 \text { to }\end{array}$ & $\begin{array}{l}\text { monitoring. } \\
\text { - Lack of capacity in modern technology for } \\
\text { dissemination and sensitization } \\
\text { A need to partner with other stakeholders } \\
\text { in dissemination and awareness raising }\end{array}$ & $\begin{array}{l}\text { - Involve other stakeholders } \\
\text { in dissemination and } \\
\text { awareness raising activities }\end{array}$ \\
\hline
\end{tabular}


Goal 6: Improved personal and material securities, reduced crime, eliminate sexual abuse and domestic violence

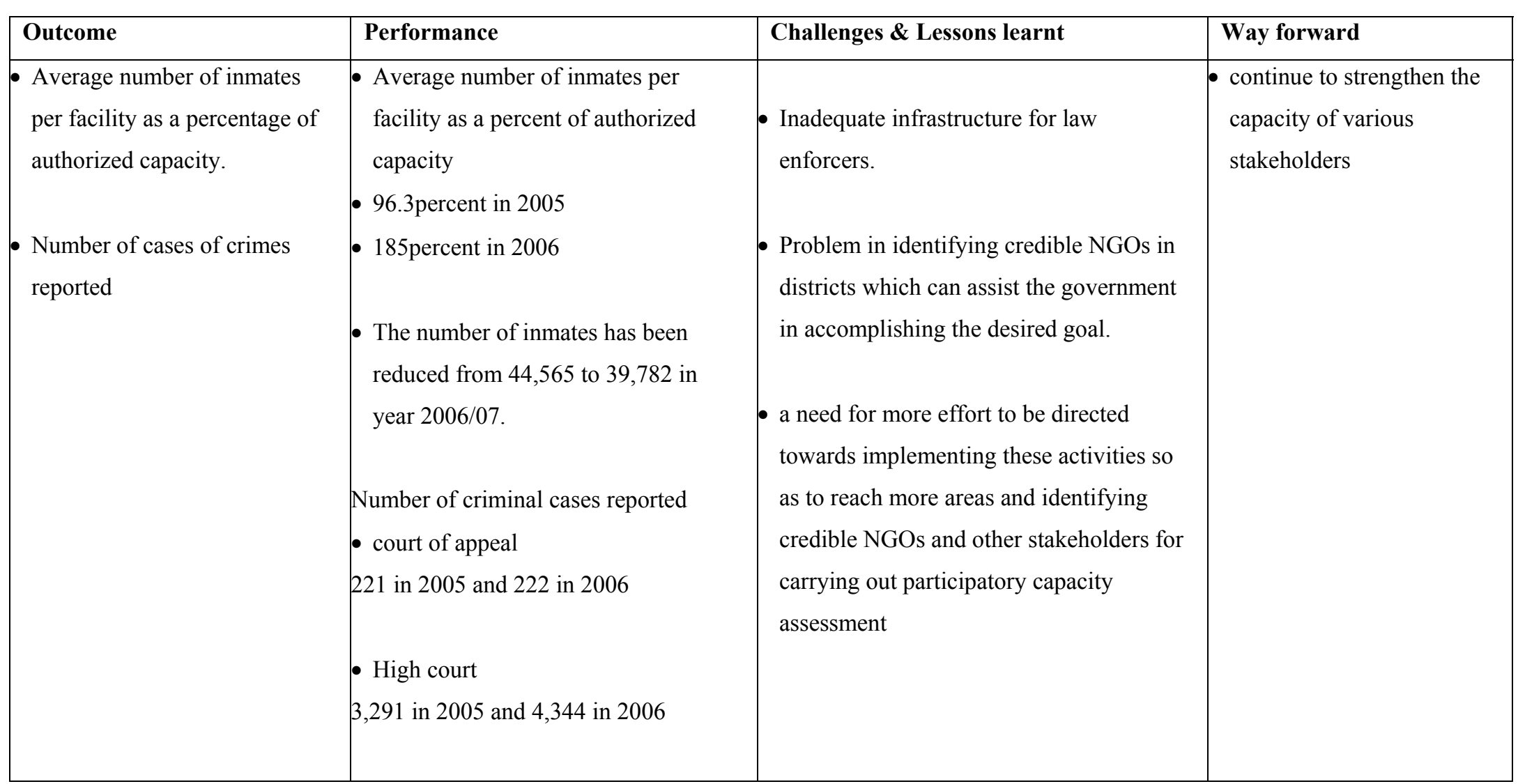




\begin{tabular}{|c|c|c|c|}
\hline Outcome & Performance & Challenges \& Lessons learnt & Way forward \\
\hline & $\begin{array}{l}\text { - District courts } \\
1998 \text { in } 2005 \text { and 22,099 in } 2006 \\
\text { - } 931 \text { prisoners serve their sentences } \\
\text { out of prisons. } \\
\text { - Expansion and rehabilitation of } \\
\text { prisons to accommodate prisoners } \\
\text { from 22,699 to 27,653. } \\
\text { - Installation of LAN/WAN connection } \\
\text { to } 7 \text { regional police stations. }\end{array}$ & & \\
\hline
\end{tabular}

\section{Goal 7: National cultural identities enhanced and promoted}

\begin{tabular}{|l|l|l|l|}
\hline Outcome & Performance & Challenges \& Lessons learnt \\
\hline - Policies, strategies and legal & & $\bullet$ Globalization hinders culture \\
frameworks for cultural and & - Two Acts (National Kiswahili & transferability to many young people \\
\hline
\end{tabular}

129

(C) International Monetary Fund. Not for Redistribution 


\begin{tabular}{|c|c|c|c|}
\hline Outcome & Performance & Challenges \& Lessons learnt & Way forward \\
\hline $\begin{array}{l}\text { moral development are in place } \\
\text { and operational. } \\
\text { - National Culture and language } \\
\text { promoted } \\
\text { - Raise awareness of sport }\end{array}$ & $\begin{array}{l}\text { Council and Film Censorship Board } \\
\text { and Stage Play under review. } \\
\text { - The Government signed a protocol for } \\
\text { establishment of Kiswahili } \\
\text { Commission for East Africa. } \\
\text { - African Union has considered } \\
\text { Kiswahili as one of the formal } \\
\text { languages and some African Leaders } \\
\text { have used Kiswahili in the AU } \\
\text { meetings. } \\
\text { - In the sports and games, the } \\
\text { government has employed } \\
\text { internationally recognized coaches. } \\
\text { - Restore sports and games at schools } \\
\text { and colleges } \\
\text { Increased awareness of copyrights for } \\
\text { artistic work }\end{array}$ & $\begin{array}{l}\text { - Inadequate culture infrastructures } \\
\text { - Shortage of open space for playing } \\
\text { issues than the urban areas }\end{array}$ & $\begin{array}{l}\text { policies, educate the } \\
\text { society on the importance } \\
\text { of national culture and } \\
\text { benefits of physical } \\
\text { exercises. } \\
\text { - Facilitate international } \\
\text { conferences to promote } \\
\text { Kiswahili }\end{array}$ \\
\hline
\end{tabular}




\section{ANNEX II: STATUS OF MKUKUTA IMPLEMENTATION FRAMEWORK}

\begin{tabular}{|c|c|c|c|}
\hline \multicolumn{4}{|c|}{ Outcome indicator: Sectoral link between SDP, LGAs plan and MKUKUTA } \\
\hline Outcome & Outputs Targets & Steps taken & Way forward \\
\hline \multirow[t]{2}{*}{$\begin{array}{l}\text { - SDPs and LGAs plan objectives } \\
\text { and actions aligned with } \\
\text { NSGRP }\end{array}$} & $\begin{array}{l}\text { - Sectors, LGAs and MDAs facilitated } \\
\text { to review their SDPs and conduct } \\
\text { situational analysis }\end{array}$ & $\begin{array}{l}\text { - Alignment of MDAs and LGAs strategic } \\
\text { plan with MKUKUTA was done and } \\
\text { SBAS and PLANREPII software was used } \\
\text { to allocate resources to MDAs Budget. }\end{array}$ & $\begin{array}{l}\text { Continue to strengthen } \\
\text { linkage of SDP and } \\
\text { LGAs plan and that of } \\
\text { MKUKUTA }\end{array}$ \\
\hline & - Progressively reviewing of Sectors & - Sectors/MDAs and LGAs have been & \\
\hline
\end{tabular}

131

(C) International Monetary Fund. Not for Redistribution 


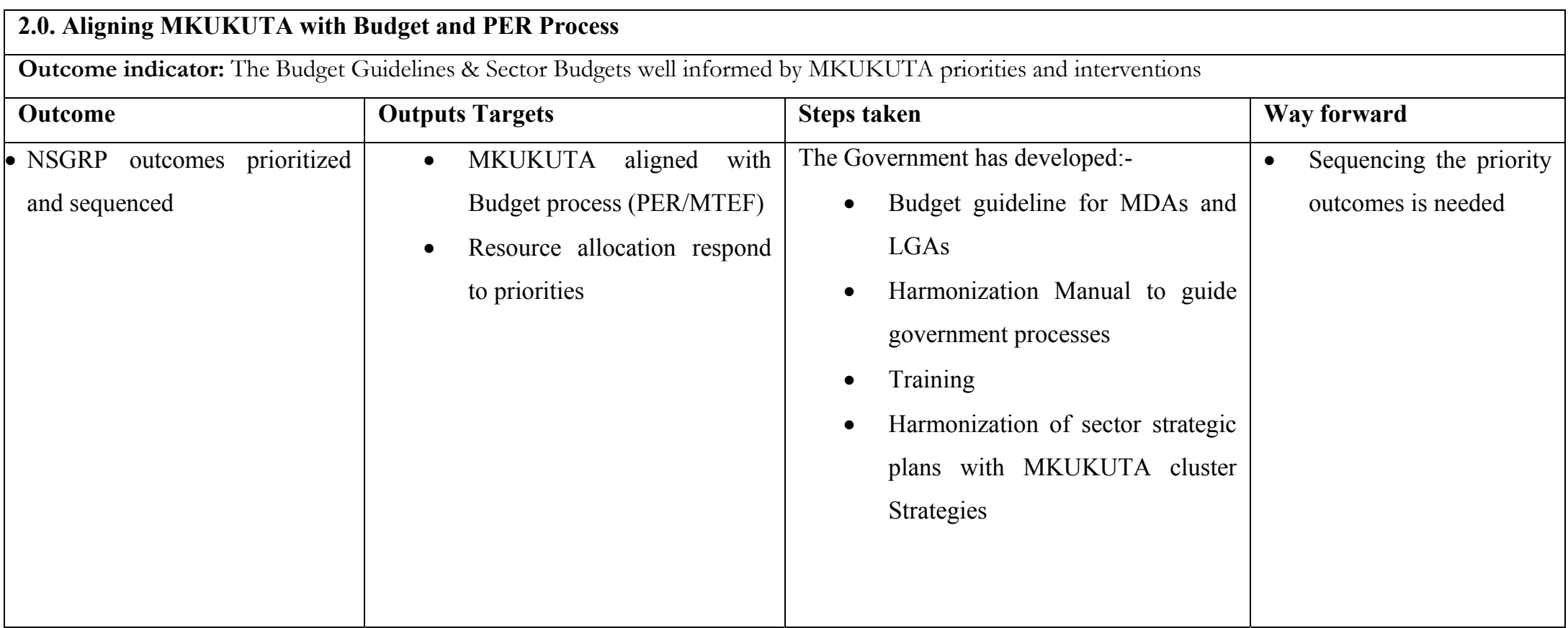

\begin{tabular}{|c|c|c|c|}
\hline \multicolumn{4}{|c|}{ 3.0. Strengthening Accountability and Reporting of Sectors and LGAs } \\
\hline Outcome & Outputs Targets & Steps taken & Way forward \\
\hline
\end{tabular}




\begin{tabular}{|c|c|c|c|}
\hline \multicolumn{4}{|c|}{ Outcome indicator: Cross-cutting issues integrated in sector programmes and LGAs development Plans } \\
\hline Outcome & Outputs Targets & Steps taken & Way forward \\
\hline $\begin{array}{l}\text { - Better outcomes in all three } \\
\text { clusters of MKUKUTA at sectors } \\
\text { level }\end{array}$ & 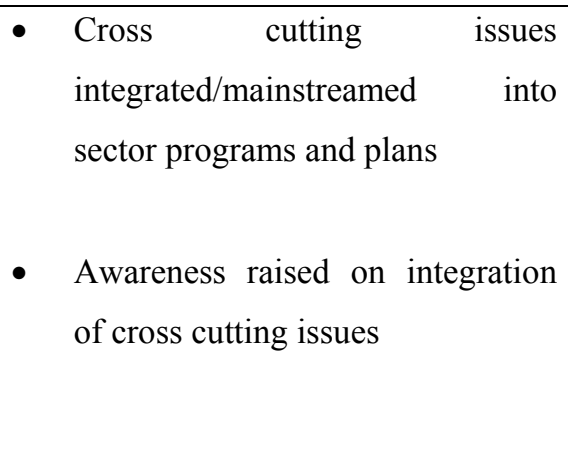 & 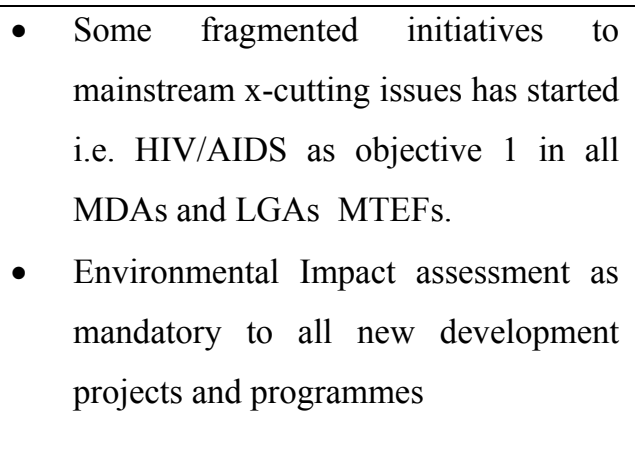 & 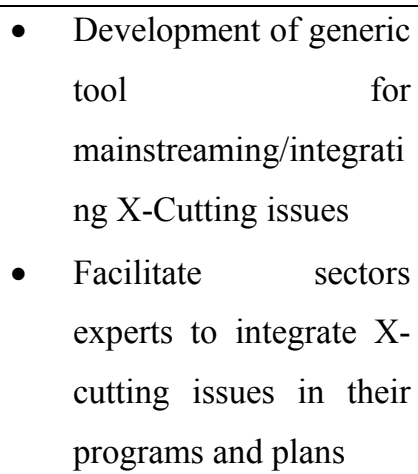 \\
\hline
\end{tabular}




\begin{tabular}{|c|c|c|c|}
\hline \multicolumn{4}{|c|}{ 6. Review and Strengthen the MMS, sector and LGA M\&E systems } \\
\hline \multicolumn{4}{|c|}{ Outcome indicator: PMS and other M\&Es reviewed } \\
\hline Outcome & Outputs Targets & Steps Taken & Way forward \\
\hline
\end{tabular}

\section{Mainstreaming MKUKUTA into NSAs policies, programmes and planning}

\section{Outcome indicator: NSAs plans aligned with MKUKUTA}

\begin{tabular}{|l|l|l|l|}
\hline Outcome & Outputs Targets & Steps taken \\
\hline - MKUKUTA cluster and X-cutting & $\bullet$ NSAs and other actors trained in $\bullet \quad$ NSAs facilitated through training on $\bullet$ NSA be facilitated to \\
issues mainstreamed in NSAs & MKUKUTA and their related fields & MKUKUTA issues \\
\hline
\end{tabular}


• Web enabled RIMKU software for $\quad$ MKUKUTA strategies and $x$ cutting issues in their plans

- Launching

Webenabled RIMKU software for NSAs 
8. Support to harmonization of key national development processes (PER, MTEF, NSGRP, TAS, PRBS, PRSC and PRGF)

Outcome indicator: Harmonized national processes

\begin{tabular}{|c|c|c|c|}
\hline Outcome & Outputs Targets & Steps taken & Way forward \\
\hline & $\begin{array}{l}\text { - NSGRP harmonized with PER/ } \\
\text { MTEF process }\end{array}$ & 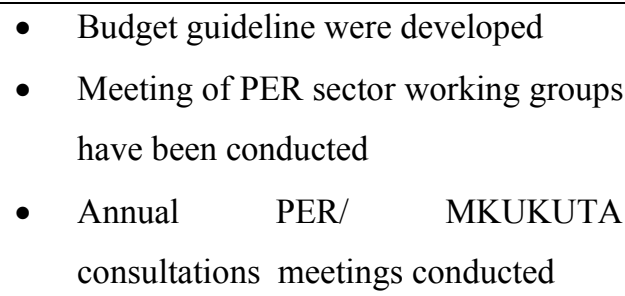 & $\begin{array}{l}\text { - Continue to improve } \\
\text { the budget guideline } \\
\text { - PER/MKUKUTA } \\
\text { annual consultations to } \\
\text { be rolled over in the }\end{array}$ \\
\hline & $\begin{array}{l}\text { - NSGRP harmonized with TAS, } \\
\text { PRBS, PRSC, and PRGF }\end{array}$ & $\begin{array}{l}\text { - Meetings between the GoT and DP on } \\
\text { harmonization has been conducted } \\
\text { - Harmonization calendar has been } \\
\text { finalize } \\
\text { - Joint missions and reviews has been } \\
\text { organized }\end{array}$ & regions and LGAs \\
\hline
\end{tabular}

\section{Operationalize the NSGRP Communication Strategy}

Outcome indicator: Communication Strategy implemented and impact assessed

\begin{tabular}{|l|l|l|}
\hline Outcome & Outputs Targets & Steps taken \\
\hline
\end{tabular}




\begin{tabular}{|c|c|c|}
\hline 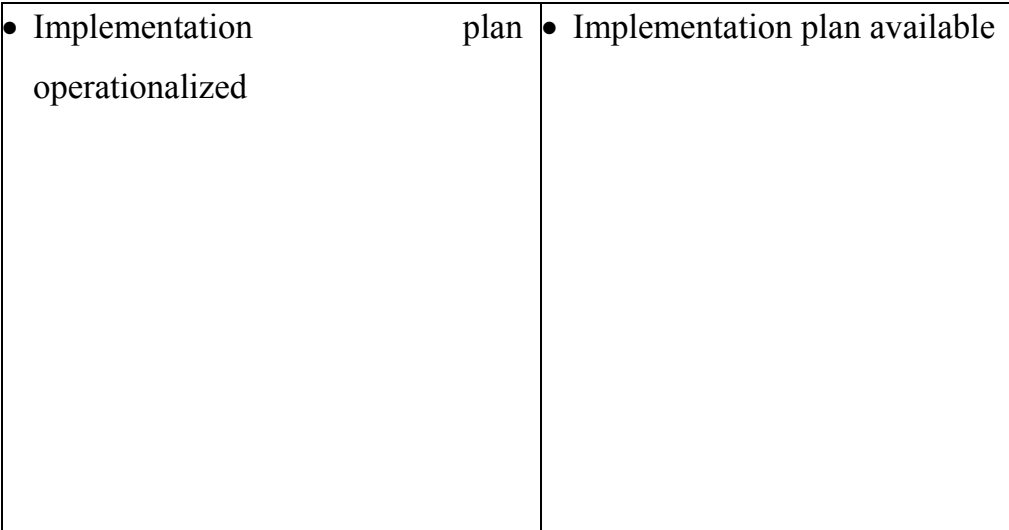 & $\begin{array}{l}\text { - Terms of reference for Views of the } \\
\text { people were developed } \\
\text { - Communication Working Group has } \\
\text { been meeting regularly }\end{array}$ & $\begin{array}{l}\text { - Prepare implementation } \\
\text { plan for NSGRP } \\
\text { Communication } \\
\text { Strategy } \\
\text { - Initiate a } \\
\text { dialogue/debate within } \\
\text { and among stakeholders } \\
\text { from the results } \\
\text { obtained on PMS. }\end{array}$ \\
\hline
\end{tabular}


10. Initiatives for ensuring inter-sector collaboration during MKUKUTA implementation

\begin{tabular}{|c|c|c|c|}
\hline Output Target & Outputs Targets & Steps taken & Way forward \\
\hline $\begin{array}{l}\text { Undertake deliberate initiatives to } \\
\text { ensure there is inter-sector } \\
\text { collaboration during MKUKUTA } \\
\text { implementation }\end{array}$ & - Circular issued and implemented & $\begin{array}{l}\text { MKUKUTA Costing exercise were } \\
\text { conducted for the following sectors:- } \\
\text { Water, Energy, Roads, agriculture, } \\
\text { Health, Education, Employment, land }\end{array}$ & $\begin{array}{l}\text { - Draft a circular on } \\
\text { MKUKUTA inter- } \\
\text { sectoral collaboration to } \\
\text { be issued by the CS } \\
\text { - Complete costing } \\
\text { exercise for the } \\
\text { remaining sectors- } \\
\text { governance, legal } \\
\text { sector, Industrial sector } \\
\text { e.t.c } \\
\text { Develop Investment } \\
\text { plan from the costing } \\
\text { exercise conducted } \\
\text { Introduce an inter- } \\
\text { sectoral module of the } \\
\text { MKUKUTA clusters } \\
\text { and targets in the new } \\
\text { TSED version } \\
\text { Strengthening of CWGs }\end{array}$ \\
\hline
\end{tabular}

11. Review of core reforms (Institutional and structural reforms) and programs 
Outcome indicator; Reforms revisited and focused on poverty reduction

\begin{tabular}{|c|c|c|c|}
\hline Outcome & Outputs targets & Steps taken & Way froward \\
\hline \multirow[t]{2}{*}{$\begin{array}{l}\text { Reforms are in harmony and } \\
\text { consistent with MKUKUTA }\end{array}$} & $\begin{array}{l}\text { - Harmonized institutions } \\
\text { structural reforms }\end{array}$ & $\begin{array}{l}\text { - Number of reforms have been } \\
\text { implemented and reviewed-LSRP, }\end{array}$ & $\begin{array}{c}\text { - Review the reforms as } \\
\text { per }\end{array}$ \\
\hline & $\begin{array}{l}\text { Core reforms and programs } \\
\text { effectively contribute to achieving } \\
\text { MKUKUTA outcomes }\end{array}$ & $\begin{array}{l}\text { PSRP, LGRP, NACSAP e.t.c. } \\
\text { - Assessment of reforms has been } \\
\text { conducted }\end{array}$ & recommendations \\
\hline
\end{tabular}


12. Development of the Social Protection Strategy and undertake further analysis of Human Rights-poverty nexus

Outcome indicator: Implementation framework fully operational

\begin{tabular}{|c|c|c|c|}
\hline Outcome & Outputs Targets & Steps taken & Way froward \\
\hline $\begin{array}{l}\text { Protection of vulnerable groups } \\
\text { from falling into poverty trap. And } \\
\text { progressive realization of Human } \\
\text { Rights }\end{array}$ & $\begin{array}{l}\text { - SP developed and implemented } \\
\text { - Human Rights integrated into } \\
\text { development frameworks }\end{array}$ & $\begin{array}{l}\text { - SP consultations conducted and } \\
\text { involved MDAs, LGAs, NSAs and } \\
\text { DPs } \\
\text { - Draft SP developed and is ready for } \\
\text { the final round of consultations } \\
\text { - }\end{array}$ & $\begin{array}{ll}\text { - } & \text { Finalize SP } \\
\text { - } & \text { Mobilize resources } \\
\text { - } & \text { Implement SP } \\
\text { - } & \text { Co-ordination and } \\
& \text { Monitoring }\end{array}$ \\
\hline
\end{tabular}

13. Scaling up implementation of the Growth Cluster

Outcome indicator: Implementation framework fully funded

\begin{tabular}{|c|c|c|c|}
\hline Outcome & Outputs Targets & Steps taken & Way froward \\
\hline $\begin{array}{l}\text { Growth rate increased from } 6 \\
\text { percent to } 10 \text { percent by } 2010\end{array}$ & - $\quad$ Increased exports $\mathrm{s}$ & $\begin{array}{l}\text { - Development of Mini Tiger Plan. } \\
\text { - Construction of the Special Economic } \\
\text { Zones } \\
\text { Identification of suitable areas for tree } \\
\text { planting }\end{array}$ & 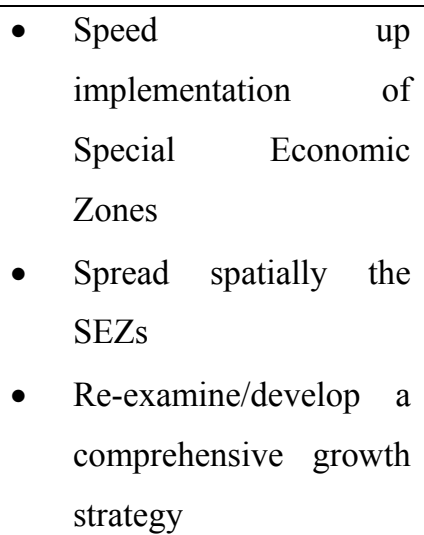 \\
\hline
\end{tabular}

140

CInternational Monetary Fund. Not for Redistribution 
14. Scaling up implementation of MKUKUTA

Outcome indicator: Update systems and strategies

\begin{tabular}{|c|c|c|c|}
\hline Outcome & Outputs Targets & Steps taken & Way forward \\
\hline $\begin{array}{l}\text { Resource Mobilization for } \\
\text { MKUKUTA updated }\end{array}$ & $\begin{array}{l}\text { Expanded Financial } r \text { Resource } \\
(\text { Domestic and external) Mobilization } \\
\text { strategy }\end{array}$ & $\begin{array}{ll}\text { - } & \text { Increased domestic resources } \\
\text { collection } & \\
\text { - } & \text { Reforms in TRA }\end{array}$ & $\begin{array}{l}\text { - Develop new Financial } \\
\text { Resource Mobilization } \\
\text { Strategy }\end{array}$ \\
\hline $\begin{array}{l}\text { Resource Allocation for } \\
\text { MKUKUTA updated }\end{array}$ & Updated SBAS and PLANREPII & - $\quad$ SBAS and PLANREP were revised & 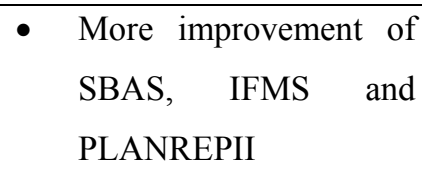 \\
\hline
\end{tabular}

\section{Strengthening MKUKUTA Reporting System}

\section{Outcome indicator: Update MKUKUTA Reporting Systems}

\begin{tabular}{|l|l|l|l|l|}
\hline Outcome & Outputs Targets & Steps taken & Way froward \\
\hline $\begin{array}{l}\text { Reporting for } \\
\text { implementation of MKUKUTA }\end{array}$ & Revised RIMKU & $\begin{array}{r}\text { RIMKU Micro and Macro software } \\
\text { were developed for both Government }\end{array}$ & Revise and update \\
updated & & RIMKU & macro \\
& & & consistency with other \\
& & & Government systems \\
\hline
\end{tabular}

16. Strengthen Human Resource to implement MKUKUTA

Outcome indicator: Human Resource Development Strategy for MKUKUTA implementation developed

\begin{tabular}{|l|l|l|l|}
\hline Outcome & Outputs Targets & Steps taken & Way froward \\
\hline
\end{tabular}




\begin{tabular}{|c|c|c|c|}
\hline $\begin{array}{l}\text { Human Resource development } \\
\text { strategy for implementing } \\
\text { MKUKUTA updated }\end{array}$ & $\begin{array}{l}\text { - Adequate staff with appropriate } \\
\text { skills for MKUKUTA } \\
\text { implementation }\end{array}$ & $\begin{array}{l}\text { - Uncoordinated capacity building } \\
\text { initiatives in MDAs, LGAs and NSAs }\end{array}$ & $\begin{array}{l}\text { - Conduct Capacity needs } \\
\text { assessment } \\
\text { - Coordinate Capacity } \\
\text { building initiatives } \\
\text { - }\end{array}$ \\
\hline
\end{tabular}

